Aus der Klinik für Hämatologie und Medizinische Onkologie

(Prof. Dr. med. L. Trümper)

der Medizinischen Fakultät der Universität Göttingen

\title{
Die Rolle des Transkriptionsfaktors LEF-1 im Hodgkin-Lymphom
}

\author{
INAUGURAL-DISSERTATION \\ zur Erlangung des Doktorgrades \\ der Medizinischen Fakultät der \\ Georg-August-Universität zu Göttingen
}

vorgelegt von

Moritz Harenberg

aus

Gießen

Göttingen 2018 
Dekan:

Referent:

Zweitgutachter:

Promotor:

Datum der mündlichen Prüfung:
Prof. Dr. rer. nat. H. K. Kroemer

Prof. Dr. rer. nat. D. Kube

Prof. Dr. rer. nat. H. Bastians

Prof. Dr. med. M. Oppermann

13.08.2019 
Hiermit erkläre ich, die Dissertation mit dem Titel

"Die Rolle des Transkriptionsfaktors LEF-1 im Hodgkin-Lymphom“ eigenständig angefertigt und keine anderen als die von mir angegebenen Quellen und Hilfsmittel verwendet zu haben.

Göttingen, den 


\section{Inhaltsverzeichnis}

Abbildungsverzeichnis ..................................................................................... III

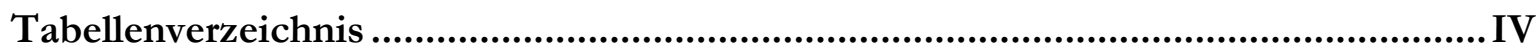

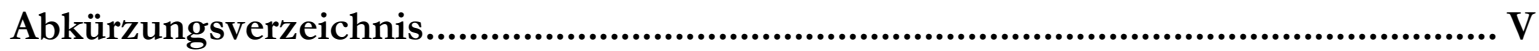

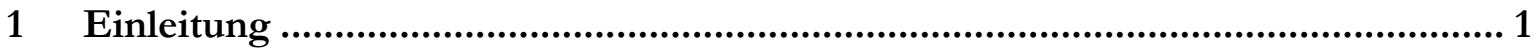

1.1 Grundlagen und Biologie des Hodgkin-Lymphoms ..................................................... 1

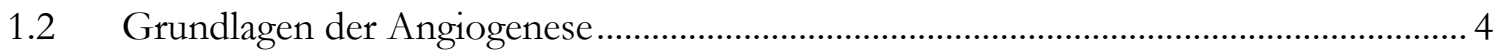

1.3 Deregulierte Signalwege in Tumoren am Beispiel des Wnt-Signalwegs ......................... 6

1.4 Klinische Aspekte und Therapieansätze des Hodgkin-Lymphoms ............................... 9

$1.5 \quad$ Vorergebnisse der Arbeitsgruppe ……………................................................................. 10

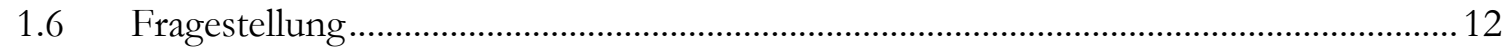

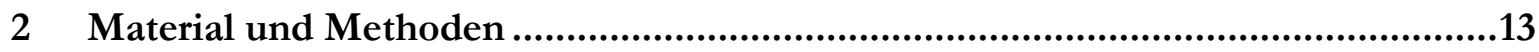

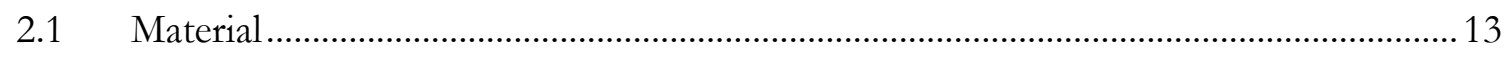

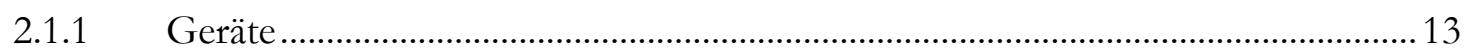

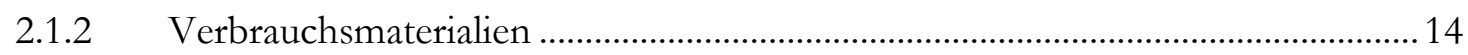

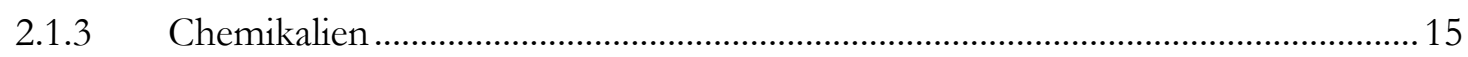

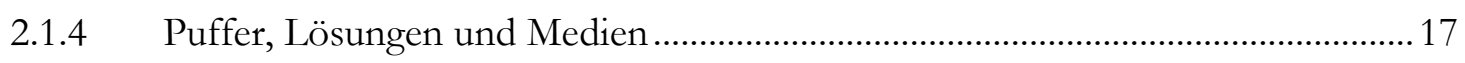

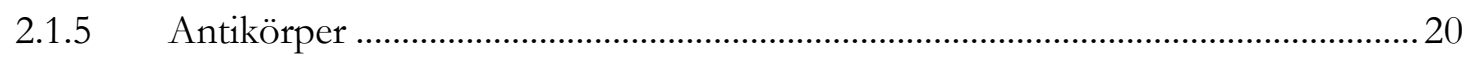

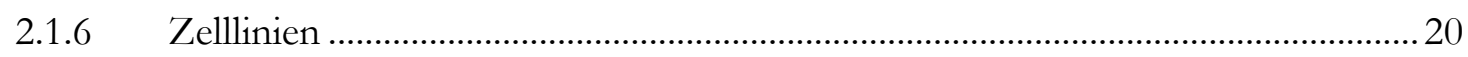

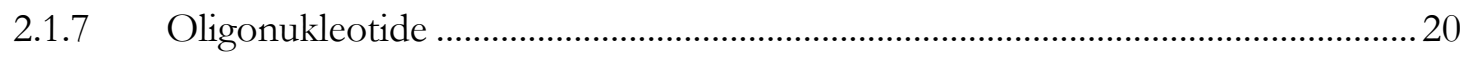

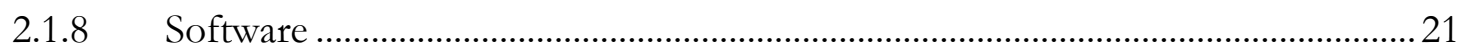

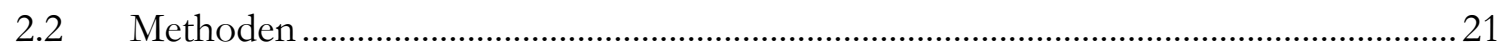

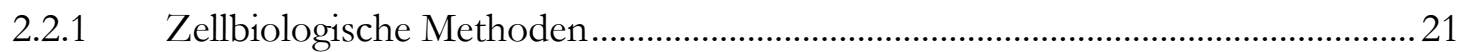

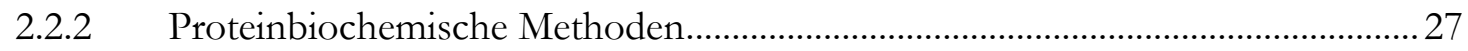

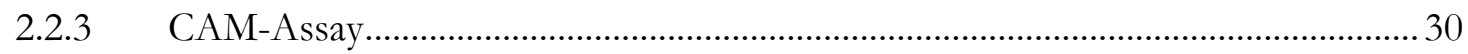

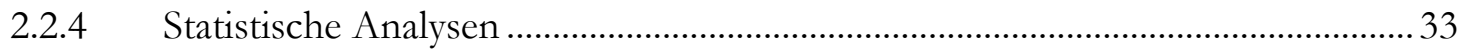

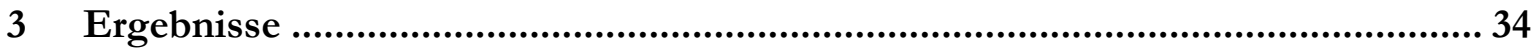

3.1 Charakterisierung der LEF-1-defizienten HL-Zellen....................................................... 34

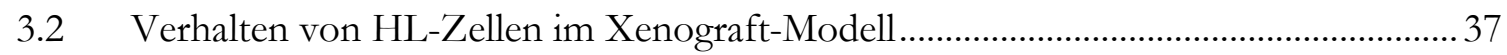

3.3 Einfluss von LEF-1 auf das Verhalten von HL-Zellen im Xenograft-Modell............ 44

3.4 Funktion von LEF-1 für die Interaktion mit Endothelzellen .......................................... 47 


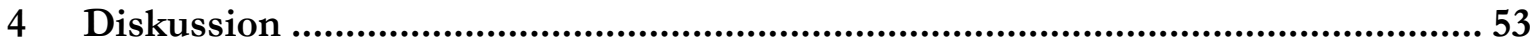

4.1 Charakterisierung des in ovo-CAM-Modells von HL-Tumoren.......................................53

4.2 Einfluss von LEF-1 auf das Verhalten im CAM-Modell...................................................55

4.3 Interaktion von HL-Zellen mit Endothelzellen .............................................................. 56

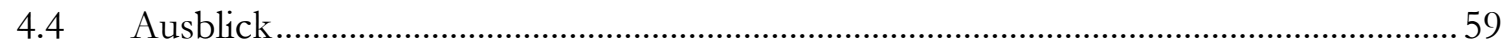

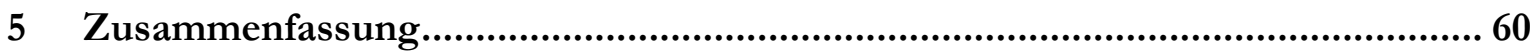

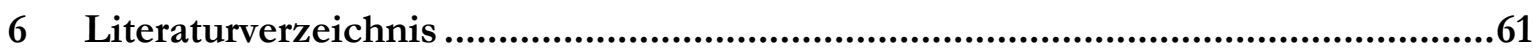




\section{Abbildungsverzeichnis}

Abbildung 1: Übersichtsbild für die Berechnung des Einblutungs-Scores.

Abbildung 2: Durchflusszytometrische Analyse von HL-Zellen nach Transduktion mit LEF-1sh-RNAund GFP-exprimierenden Lentiviren.

Abbildung 3: Untersuchung der LEF-1-Expression und der LEF-1-Proteinmenge in HL-Zellen nach Expression einer LEF-1shRNA.

Abbildung 4: Die Zellverdopplung der HL-Zelllinie L-428 ist nicht abhängig von der LEF-1-

Expression. .36

Abbildung 5: Großflächige Einblutungen in Lymphomen der HL-Zelllinien auf der CAM.

Abbildung 6: Feingewebliche Analysen der Lymphome zeigen großflächige Einblutungen.

Abbildung 7: In Lymphomen auf der CAM sind Hinweise für eine beginnende Gefäßinvasion erkennbar.

Abbildung 8: Semidünnschnitte von HL-Tumoren zeigen Einblutungen.

Abbildung 9: Immunfluoreszenz-Aufnahmen zeigen Blut- und Lymphgefäße in physiologischer CAM.

Abbildung 10: HL-Tumoren auf der CAM enthalten irregulär strukturierte Blutgefäße. 42

Abbildung 11: In HL-Tumoren auf der CAM sind fast keine Lymphgefäße zu finden.

Abbildung 12: Ex ovo-CAM-Assays zeigen, dass HL-Zellen entlang von Gefäßen aus dem Tumor herauswachsen.

Abbildung 13: Der LEF-1-Knockdown führt zu einer signifikanten Erniedrigung der Tumorgröße im Xenograft-Modell von L-428 B-Zellen.

Abbildung 14: Ein LEF-1-Knockdown hat keinen Einfluss auf die Einblutungen von HL-Tumoren im CAM-Assay.

Abbildung 15: LEF-1 beeinflusst die Fähigkeit von HL-Zellen, HUVECs zu invasiver Migration anzuregen.

Abbildung 16: LEF-1 beeinflusst die Fähigkeit von HL-Zellen, HUVECs zur Wundheilung zu stimulieren

Abbildung 17: Die VEGFA-Expression ist in HL-Zellen mit verminderter LEF-1-Proteinmenge nicht signifikant verändert. 
Abbildung 18: Bestimmungen der VEGF-A-Konzentration im konditionierten Medium von HLZellen.

\section{Tabellenverzeichnis}

Tabelle 1: Verwendete Geräte.

Tabelle 2: Verwendete Verbrauchsmaterialien.

Tabelle 3: Verwendete Chemikalien. ....

Tabelle 4: Verwendete Puffer, Lösungen und Medien. 17

Tabelle 5: Verwendete Antikörper mit Angabe der verwendeten Verdünnung... 20

Tabelle 6: Verwendete Zelllinien......

Tabelle 7: Verwendete Oligonukleotidsequenzen. 20

Tabelle 8: Verwendete Software. 21

Tabelle 9: Übersicht über die Mittelwerte im Einblutungs-Score.. 46 


\section{Abkürzungsverzeichnis}

ALL

akut lymphoblastische

Leukämie

$\begin{array}{ll}\text { ANOVA } & \begin{array}{l}\text { analysis of variance, } \\ \text { Varianzanalyse }\end{array} \\ \text { APS } & \text { Ammoniumpersulfat } \\ \text { BL } & \text { Burkitt-Lymphom } \\ \text { BSA } & \text { bovines Serumalbumin } \\ \text { CAM } & \text { Chorion-Allantois-Membran } \\ \text { CD } & \text { cluster of differentiation, } \\ & \text { Oberflächenmerkmal auf } \\ & \text { Zellen }\end{array}$

cDNA complementary $D N A$, komplementäre DNA

CLL chronisch lymphozytische Leukämie

CM konditioniertes Medium

DAPI

DLBCL

DMSO

DNA

EBV

EDTA

ELISA

FCS

fwd

GAPDH

GFP
4',6-Diamidin-2-phenylindol

diffuse large B cell lymphoma, diffus-großzelliges B-Zell-

Dimethylsulfoxid

Desoxyribonukleinsäure

Epstein-Barr-Virus

Ethylendiamintetraacetat

ensyme linked immuno-sorbent assay

fetal calf serum, Zusatzstoff zu Zellkulturmedien

forward, bezeichnet den Primer am 5'-Ende eines Gens

Glycerinaldehyd-3-phosphat-

Dehydrogenase

green gluorescent protein, grün

fluoreszierendes Protein Lymphom
$\mathrm{HE}$

HL

HRP

HRS-Zellen

LEF-1

Mep21

mRNA

NHL

ns

PAGE

PBS

PCR

PFA

pGIPZ

Prox1

PVDF

qRT-PCR

rev

RNA
Hämatoxylin \& Eosin, Färbung

Hodgkin-Lymphom

horseradish peroxidase, Meerrettich-Peroxidase

Hodgkin-Reed-SternbergZellen

buman umbilical vein endothelial cells, humane Nabelschnurvenen-Endothelzellen lymphoid enbancer-binding factor 1 Myb-Ets-transformed multipotent hematopoietic precursor 21 messenger RNA

Non-Hodgkin-Lymphom

non-silencing

Polyacrylamid-

Gelelektrophorese

phosphate-buffered saline, phosphatgepufferte Salzlösung

polymerase chain reaction, Polymerase-Kettenreaktion

Paraformaldehyd

für die Transduktion genutzter, lentiviraler Vektor

Prospero Homeobox 1

Polyvinylidenfluorid

quantitative Reverse-

Transkriptase-Polymerase-

Kettenreaktion

reverse, bezeichnet den Primer am 3'-Ende eines Gens

Ribonukleinsäure 
RPMI-1640 Roswell Park Memorial Institute,

Grundlage für

Zelllkulturmedien

SD

standard derivation,

Standardabweichung

SDS sodiumdodecylsulfat, Natrium-

Dodecylsulfat

shRNA short hairpin $\mathrm{RNA}$

STAT signal transducer and activator of transcription
TBS-T tris-buffered saline and tween, Tris-gepufferte Salzlösung mit Tween

TCF transcription factor

TEMED Tetramethylethylendiamin

$\operatorname{VEGF}(-\mathrm{A}) \quad$ vascular endothelial growth factor $(-A)$

Wnt Wortschöpfung aus Wingless (Wg) und Integration 1 (int) 


\section{Einleitung}

\subsection{Grundlagen und Biologie des Hodgkin-Lymphoms}

Maligne Lymphome sind bösartige Erkrankungen des lymphatischen Systems. Sie gehen meist von Lymphknoten aus, können aber auch andere lymphatische Organe, wie die Milz, oder extralymphatische Organe befallen. Aus historischen Gründen werden die malignen Lymphome histologisch in Hodgkin-Lymphome (HL) und Non-Hodgkin-Lymphome (NHL) unterschieden.

Das Hodgkin-Lymphom wurde erstmals 1832 von dem britischen Arzt Thomas Hodgkin als eigenständiges Krankheitsbild beschrieben (Hodgkin 1832). Es gehört heute zu den häufigsten malignen Lymphomen, zeichnet sich aber durch eine sehr gute Prognose aus, da mit modernen Therapieansätzen bei 80 bis 90 Prozent der Patienten eine Heilung erreicht werden kann (Ansell 2014). Allerdings gibt es weiterhin Schwierigkeiten bei der Behandlung von Hodgkin-Lymphom-Patienten, zum Beispiel die Wahl der richtigen Therapie für fortgeschrittene Stadien oder die Langzeitfolgen der Polychemotherapien (Montanari und Diefenbach 2014; LeMieux et al. 2015).

Mit einer Inzidenz von 2 - 4 Neuerkrankungen pro 100.000 Einwohnern und Jahr ist das Hodgkin-Lymphom eines der häufigsten Lymphome in der westlichen Welt (Thomas et al. 2002; Küppers et al. 2012). Die Inzidenzkurve in Industrienationen verläuft bimodal, mit Häufigkeitsgipfeln im Alter zwischen 20 und 35 Jahren und ab 60 Jahren (Thomas et al. 2002). Im Gegensatz dazu gibt es in Entwicklungsländern eine vielfach höhere Zahl an Erkrankungen bei Kindern und Jugendlichen, während die Inzidenz dort mit dem Alter abnimmt (Thomas et al. 2002). Männer sind insgesamt etwas häufiger vom HodgkinLymphom betroffen als Frauen (Thomas et al. 2002).

Die genaue Ätiologie des Hodgkin-Lymphoms ist bis heute ungeklärt, jedoch gibt es bedeutende Risikofaktoren, zum Beispiel virale Infektionen, welche die Krankheitsentstehung begünstigen können (Küppers 2009). Der wichtigste Risikofaktor ist die Infektion mit dem Epstein-Barr-Virus (EBV), welches 40 Prozent der Patienten in westlichen Ländern und bis zu 90 Prozent der Erkrankten in Entwicklungsländern betrifft (Glaser et al. 1997). Es wird vermutet, dass das EBV eine substantielle Rolle im Transformationsprozess der Erkrankung spielt (Küppers 2009).

Weiterhin haben direkte Familienangehörige von HL-Patienten ein drei- bis neunfach 
erhöhtes Risiko, ebenfalls an HL zu erkranken, was für eine genetische Teilkomponente in der Krankheitsentstehung spricht (Grufferman et al. 1977; Thomas et al. 2002).

Nach Richtlinien der WHO wird das Hodgkin-Lymphom in fünf histologische Subtypen eingeteilt. Die beiden häufigsten Subtypen sind der Typ der Nodularsklerose, welcher vor allem während des ersten Altersgipfels auftritt und etwa 50 bis 80 Prozent der Erkrankten ausmacht, sowie der Typ der gemischten Zellulärität, welcher bei circa 20 bis 30 Prozent der Patienten zu finden ist (Eberle et al. 2009). Die selteneren Subtypen umfassen den Typ der lymphozytenreichen Form, den der lymphozytenarmen Form sowie den Typ des nodulären lymphozyten-prädominanten Hodgkin-Lymphoms (NLPHL) (Eberle et al. 2009). Die vier erstgenannten Subtypen werden als klassisches Hodgkin-Lymphom (cHL) dem NLPHL gegenübergestellt (Swerdlow et al. 2008), da sie sich in Biologie und Therapie unterscheiden.

Besonderes mikroskopisches Merkmal des Hodgkin-Lymphoms im Vergleich zu allen anderen Tumorentitäten ist die Tatsache, dass die malignen Zellen nur etwa ein Prozent der gesamten Tumormasse ausmachen, während sich der Rest aus infiltrierenden Immunzellen wie T-Lymphozyten, Monozyten und eosinophilen sowie basophilen Granulozyten zusammensetzt (Küppers 2009). Die entarteten Zellen sind mikroskopisch als sehr große, einkernige Hodgkin-Zellen beziehungsweise mehrkernige Reed-Sternberg-Zellen zu erkennen, meist werden diese als Hodgkin-Reed-Sternberg-Zellen (HRS-Zellen) zusammengefasst (Thomas et al. 2004). HRS-Zellen exprimieren das Transmembranprotein cluster of differentiation 30 (CD30), was diagnostische und therapeutische Relevanz hat und zur sicheren Identifizierung der Tumorzellen dienen kann (Küppers 2009).

Alle Lymphome sind maligne Erkrankungen der Zellen des adaptiven Immunsystems, dessen zelluläre Bestandteile sich im Wesentlichen aus B- und T-Zellen zusammensetzen. Der mit etwa 85 Prozent überwiegende Teil der Lymphome ist B-Zell-Ursprungs, während der kleinere Teil aus entarteten T-Zellen entsteht (Herold 2014).

Naive B-Zellen gelangen über spezialisierte Blutgefäße, sogenannte hochendotheliale Venolen (HEV), in den Lymphknoten (Girard et al. 2012). Über eine enge Interaktion von B-Zelle und Endothelzelle der HEV kommt es zur Extravasation der B-Zellen, welche im Anschluss die B-Zell-Follikel des Lymphknotens durchwandern (Girard et al. 2012). Erkennen sie dabei mit ihrem B-Zell-Rezeptor ein von einer follikulären dendritischen Zelle präsentiertes Antigen, migrieren die aktivierten B-Zellen an den Rand des Follikels, um dort von antigenspezifischen, CD4-positiven T-Zellen co-aktiviert zu werden (Vinuesa et al. 2010). Nach dieser Co-Aktivierung wandern die B-Zellen in das Zentrum des Follikels und bilden dort das sogenannte Keimzentrum. Hier finden der Klassenwechsel des Immunglobulin-Rezeptors 
sowie eine somatische Hypermutation der variablen Region der Immunglobulin-RezeptorGene statt (Hamel et al. 2012). Diese Vorgänge finden ausschließlich in B-Zellen statt und dienen dazu, in aktivierten B-Zellen die Affinität des B-Zell-Rezeptors für das spezifische Antigen zu erhöhen und eine effektive und dauerhafte Immunantwort zu ermöglichen (Hamel et al. 2012). Allerdings kann dieser hoch proliferative und mutagene Vorgang in seltenen Fällen zur malignen Transformation von B-Zellen führen, weshalb die Mehrzahl der NHL auch auf entartete Keimzentrums-B-Zellen zurückzuführen sind (Basso und Dalla-Favera 2015). Während die Tumorzellen von NHL in der Regel entsprechend ihrem B-Zell-Ursprung einen B-Zell-ähnlichen Immunphänotyp aufweisen, präsentieren HRS-Zellen Oberflächenmerkmale unterschiedlichster Zelltypen (Küppers et al. 2012). Sie tragen keinen B-Zell-Rezeptor mehr (Kanzler et al. 1996), können aber sowohl T-Zell-Merkmale wie CD3 als auch B-Zell-Marker wie CD20 oder Pax5 exprimieren (Schwering et al. 2003; Küppers 2009). Küppers et al. (1994) konnten letztendlich den Ursprung der HRS-Zellen aus entarteten Keimzentrums-B-Zellen nachweisen, da sie fast immer somatisch mutierte und neu angeordnete Immunglobulin-Gene tragen.

Der Verlust des B-Zell-Rezeptors würde in einer physiologischen Situation zur Einleitung der Apoptose einer B-Zelle führen. HRS-Zellen häufen indes im Rahmen ihrer malignen Transformation eine Vielzahl von Mutationen an, die sie immun gegenüber den Apoptoseinduzierenden Signalen des Keimzentrums machen (Küppers et al. 2012). Die auf diese Weise transformierten HRS-Zellen formen in der Folge aktiv ihre direkte Umgebung um, indem sie verschiedene Zellen wie eosinophile und basophile Granulozyten, Mastzellen sowie Fibroblasten anziehen (Aldinucci et al. 2010). Am besten beschrieben ist die Interaktion der HRS-Zellen mit T-Helferzellen, von denen sie überlebensfördernde Signale bekommen können (Liu et al. 2014). Diese CD4-positiven T-Lymphozyten bewirken zum Beispiel über Aktivierung von CD40-Rezeptoren der Tumorzelle eine Verhinderung der Apoptose und sind im mikroskopischen Schnitt selbiger als Rosetten-Zellen direkt angelagert (Küppers 2009; Steidl et al. 2011).

Einer der wichtigsten negativen Prognosefaktoren des Hodgkin-Lymphoms ist die Dissemination der Tumorzellen (Venkataraman et al. 2014). Der überwiegende Teil der Verbreitung der malignen Zellen geschieht über die Lymphgefäße und angrenzende Lymphknoten, jedoch kommt es in einigen Fällen auch zu einer Verbreitung über Blutgefäße (Guermazi et al. 2001). Bislang liegen allerdings nur sehr wenige Daten zur Interaktion von HL-Zellen mit Blutendothelzellen vor. Estrada-Bernal et al. (2003) zeigten, dass HL-Zellen mittels sezernierter Faktoren Einfluss auf den Phänotyp von Endothelzellen nehmen können, um die Adhäsion von Lymphom-Zellen an Gefäße zu erleichtern. Die in dieser Arbeit 
verwendete HL-Zelllinie L-428 exprimiert in Normoxie und Hypoxie den pro-angiogenen Wachstumsfaktor vascular endothelial growth factor A (VEGF-A), was für eine Bedeutung von Angiogenese im Prozess der Ausbreitung der Krankheit spricht (Doussis-Anagnostopoulou et al. 2002).

\subsection{Grundlagen der Angiogenese}

Allgemein bezeichnet Angiogenese die Bildung von neuen aus bereits bestehenden Gefäßen, im Gegensatz zur Vaskulogenese, welche die komplette Neubildung von Gefäßen aus mesenchymalen Stammzellen beschreibt (Potente et al. 2011).

Der Vorgang der Angiogenese spielt vor allem in Entwicklung und Wachstum eines Organismus eine große Rolle, ist aber ebenso essenziell für die Wundheilung (Matsumoto und Ema 2014). Außerdem wurde die Angiogenese schon sehr früh von Folkman (1971) als wichtige Voraussetzung für das Wachstum und die Dissemination von Tumoren beschrieben, eine Beobachtung, die seitdem in mehreren Arbeiten bestätigt wurde (Roorda et al. 2010; Matsumoto und Ema 2014).

Im Zentrum des Prozesses der Angiogenese stehen die Endothelzellen, welche die Innenwand von Gefäßen auskleiden und über Jahre hinweg ruhen können (Eilken und Adams 2010). In ruhenden Gefäßen herrscht ein Gleichgewicht aus pro-angiogenen und anti-angiogenen Substanzen. Zur Einleitung der Angiogenese müssen von umliegenden Zellen, zum Beispiel von Fibroblasten oder inflammatorischen Zellen, pro-angiogene Faktoren wie VEGF-A, Angiopoietin, fibroblast growth factor (FGF) oder transforming growth factor $\beta$ (TGF $\beta$ ) ausgeschüttet werden (Ferrara und Henzel 1989; Carmeliet und Jain 2011). VEGF-A besitzt unter diesen die höchste Relevanz für die Angiogenese und ist der wichtigste Bestandteil einer fünf Proteine umfassenden Gruppe von Wachstumsfaktoren (Ferrara et al. 2003; Adams und Alitalo 2007; Carmeliet und Jain 2011). Durch die Bindung von VEGF-A an seinen Rezeptor wird eine Signalkaskade in Gang gesetzt, welche die Motilität und Invasivität von Endothelzellen erhöht (Adams und Alitalo 2007).

Dies führt während der Angiogenese dazu, dass zuvor ruhende Endothelzellen zu Migration und Proliferation angeregt werden, die Basalmembran zersetzen und aus dem Gefäß in Richtung des proangiogenen Signals aussprießen (Ferrara et al. 2003). Dabei wird sichergestellt, dass stets nur eine Zelle, die sogenannte Tip-Zelle, die Führung übernimmt und die anderen Zellen ihr beim Auswachsen folgen (Chappell et al. 2011). Treffen sich die Führungszellen zweier auswachsender Stränge, bilden diese eine feste Bindung aus, und innerhalb des Zellstrangs kommt es durch Vakuolenbildung zur Bildung eines Lumens 
(Potente et al. 2011). Die Scherkräfte des nun durch das Lumen fließenden Blutes sowie das erhöhte Sauerstoffangebot führen zur Stabilisierung des neuen Gefäßes und abschließend zur Anlagerung von Perizyten (Chappell et al. 2011).

Eine pathologisch gesteigerte Angiogenese ist eines der Kerncharakteristika von malignen Tumoren (Hanahan und Weinberg 2000). So konnte beispielsweise gezeigt werden, dass VEGFA-mRNA in so gut wie allen soliden Tumoren exprimiert wird (Ferrara und DavisSmyth 1997). Kann sich ein Tumor zu Beginn seiner Expansion noch allein durch Diffusion ernähren, wird er dafür schnell zu groß, sodass es in seinem Zentrum zu einer Hypoxie mit anschließender, unkontrollierter Sekretion pro-angiogener Signale wie VEGF-A kommt (Shweiki et al. 1992; Ferrara et al. 2003). Die daraufhin in den Tumor einwachsenden Gefäße sind durch das fehlende Zusammenspiel der pro- und anti-angiogenen Botenstoffe schlecht organisiert, die Gefäßwände sind durchlässiger als in physiologischen Gefäßen und eine Stabilisierung des Gefäßes durch Anlagerung von Perizyten findet nicht statt (Potente et al. 2011; Claesson-Welsh und Welsh 2013). Auf diese Weise konfigurierte Gefäße werden leaky vessels genannt, ihr Vorliegen ist typisch für maligne Neoplasien (Dudley 2012). De Bock et al. (2011) fassten in einer Übersichtsarbeit die Auswirkungen dieser abnormen Konfiguration von Tumorgefäßen zusammen und nannten dabei eine erhöhte Invasivität und Dissemination als mögliche Konsequenzen. Diese sind möglicherweise dadurch bedingt, dass die Tumorzellen durch die unphysiologischen Gefäße unzureichend versorgt werden und infolgedessen die Angiogenese weiter steigern. Letztendlich könnten die Tumorzellen über die vermehrt vorliegenden abnormen Gefäße mit erhöhter Wahrscheinlichkeit disseminieren (De Bock et al. 2011).

Über die beschriebene Relevanz in soliden Tumoren hinaus spielt Angiogenese außerdem eine wichtige Rolle in der Entstehung von hämatologischen Neoplasien. Neben dem HodgkinLymphom exprimieren auch die meisten Non-Hodgkin-Lymphome VEGF-A und andere pro-angiogene Wachstumsfaktoren und sorgen so für eine gesteigerte Gefäßdichte innerhalb des Tumors (Ribatti et al. 2013). Diese gesteigerte Gefäßdichte ist in aggressiven B-NHL, wie dem diffus-großzelligem B-Zell-Lymphom (DLBCL) oder dem Burkitt-Lymphom (BL), mit einem unreifen Phänotyp der Endothelzellen assoziiert (Passalidou et al. 2003). Weiterhin konnten Cardesa-Salzmann et al. (2011) zeigen, dass bei mit Immunochemotherapie behandelten DLBCL-Patienten die mittlere Gefäßdichte des Tumors ein unabhängiger Prognosefaktor ist, der mit einem schlechteren progressionsfreien und Gesamtüberleben korreliert ist.

Für das cHL hingegen existieren wenig Daten über die morphologischen Charakteristika der Blutgefäße innerhalb des Tumors (Marinaccio et al. 2014). Weiterhin liegen nach Marinaccio et 
al. (2014) noch keinerlei Daten aus einem in vivo-Modell zur Beurteilung der Angiogenese im Hodgkin-Lymphom vor.

Das Modell der Chorion-Allantois-Membran (CAM) von Hühnereiern ist ein anerkannter Standardversuch zur Untersuchung der Angiogenese (Ribatti 2014). Klingenberg et al. (2014) zeigten Daten zum Einsatz des CAM-Modells für die Untersuchung des Burkitt-Lymphoms, zum Einsatz für das cHL lagen zu Beginn dieser Arbeit noch keine Daten vor.

Die vorliegenden Befunde zur Relevanz der Angiogenese in verschiedensten Krebserkrankungen führten zur Entwicklung mehrerer anti-angiogener Therapien, wobei die meisten an VEGF-A oder seinen Rezeptoren ansetzen (Welti et al. 2013). Bisher konnte allerdings keine der mittlerweile zugelassenen anti-angiogen wirksamen Therapeutika die hohen Erwartungen erfüllen (Kieran et al. 2012; Welti et al. 2013). Meist kommt es bei Therapie mit anti-angiogenen Wirkstoffen nur zu einer kurzen Unterbrechung des Tumorwachstums, mutmaßlich auf der Basis von Resistenzentwicklungen (Ebos et al. 2009). Dies offenbart ein nach wie vor mangelndes Verständnis der zu Grunde liegenden Vorgänge innerhalb des Tumors und seiner Umgebung und verdeutlicht die Notwendigkeit weiterer Forschung in diesem Bereich (Potente et al. 2011).

\subsection{Deregulierte Signalwege in Tumoren am Beispiel des Wnt-Signal- wegs}

Hanahan und Weinberg (2000) postulierten sechs Kernmerkmale von Krebszellen. Dazu zählten sie unter anderem die Unabhängigkeit von Wachstumssignalen, die fehlende Empfindlichkeit auf Anti-Wachstumssignale sowie die bereits erläuterte Deregulierung der Angiogenese (Hanahan und Weinberg 2000). Grundlage dieser Merkmale sind sehr oft Fehlregulationen und Mutationen innerhalb des komplizierten Netzwerkes von Signalwegen innerhalb einer Zelle (Hanahan und Weinberg 2000; Hanahan und Weinberg 2011).

Dieses Phänomen ist auch im Hodgkin-Lymphom zu beobachten. Das gesamte Transkriptionsnetzwerk der HRS-Zellen ist dereguliert, da Transkriptionsfaktoren wie beispielsweise Nuclear Factor- KB (NF- KB) und Signal Transducer and Activator of Transcription 5a (STAT5A), STAT5B sowie STAT3 aberrant überexprimiert sind (Bargou et al. 1996; Kube et al. 2001; Scheeren et al. 2008). Typische B-Zell-Faktoren wie POU class 2 associating factor 1 (auch bekannt als BOB1), POU class 2 bomeobox 2 (auch bekannt als OCT2) und PU.1 fehlen hingegen, wodurch es zu einer Reprogrammierung der entarteten Zellen kommt (Küppers 2009). Diese fehlerhafte Ausprägung von Signalwegen erklärt den bereits beschriebenen 
besonderen Phänotyp von HRS-Zellen, der neben B-Zell-Markern auch Marker zahlreicher anderer Zelltypen aufweist (Küppers 2009).

Wie bereits besprochen, zeichnet sich das Hodgkin-Lymphom durch eine besonders enge Interaktion von Tumorzellen und Zellen des Infiltrates aus (Steidl et al. 2011; Liu et al. 2014). Die oben genannten, deregulierten Signalwege ermöglichen es den Tumorzellen, sich eine Mikroumgebung, die das Tumorzellüberleben begünstigt, zusammenzustellen (Liu et al. 2014). Doch auch in anderen hämatologischen Krebserkrankungen spielt die Beeinflussung der Tumorzellen durch die Zellen der direkten Umgebung eine Rolle. Derksen et al. (2004) beschrieben einen aktiven Wnt-Signalweg in Tumorzellen des Multiplen Myeloms, die hierdurch von umgebenden Zellen zur Proliferation angeregt werden. Weiterhin ist auch in der chronisch lymphozytischen Leukämie (CLL) der Wnt-Signalweg und der zugehörige Transkriptionsfaktor LEF-1 als dereguliert beschrieben (Lu et al. 2004; Gutierrez et al. 2010).

Der Wnt-Signalweg ist ein sehr häufig in Krebsentitäten als dereguliert beschriebener Signalweg (Polakis 2012). Besonders für das Kolon-Karzinom ist die tragende Rolle dieses Signalweges in der Entstehung und Progression der Tumorzellen weitreichend belegt (Bienz und Clevers 2000; Polakis 2012). „Wnt“ ist eine Wortneuschöpfung aus den Begriffen Wingless und Integration-1, zwei homologen Genen der Taufliegengattung Drosophila und Säugetieren, die als erste dem neuentdeckten Signalweg zugeordnet werden konnten (Nusse et al. 1991).

Wnts umfassen eine Familie hoch konservierter Proteine, die als Signalmoleküle physiologisch eine tragende Rolle in der Embryonalentwicklung und Wundheilung spielen (Clevers 2006). Es sind drei unabhängige Signaltransduktionswege beschrieben; dies sind der kanonische WntSignalweg, der $\mathrm{Ca}^{2+}$-Signalweg sowie der planar cell polarity-Signalweg (PCP-Signalweg) (Clevers 2006). Die beiden letztgenannten werden auch als nicht-kanonische Wnt-Signalwege bezeichnet. Sie erreichen ihre Wirkung unabhängig von $\beta$-Catenin und haben Einfluss auf die Polarität und Migrationsfähigkeit einer Zelle (Veeman et al. 2003). Hingegen bewirkt eine Aktivierung des kanonischen Wnt-Signalwegs, mit dem sich diese Arbeit befasst, eine Stabilisierung zytosolischen $\beta$-Catenins, das daraufhin in den Zellkern translozieren kann und dort als Signalmolekül wirkt (Clevers 2006).

In Abwesenheit eines Wnt-Signals wird $\beta$-Catenin im Zytosol fortlaufend durch einen Proteindestruktionskomplex zur Degradation im Proteasom markiert und kann somit nicht in den Zellkern translozieren (Munemitsu et al. 1995; Aberle et al. 1997). Dieser Destruktionskomplex besteht aus mehreren Proteinen, die zusammen als Tumorsuppressoren wirken können, indem sie die Signalübertragung über $\beta$-Catenin unterbinden (Munemitsu et al. 1995; Clevers 2006). 
Bindet ein Wnt-Ligand an seinen Rezeptor der Frizzled-Familie, wird die Wnt-Signalkaskade in Gang gesetzt (Bhanot et al. 1996). Über eine Interaktion mit dem Protein Dishevelled wird dabei der Degradationskomplex aufgelöst, wodurch die zytosolische $\beta$-Catenin-Konzentration ansteigt und dieses in den Kern translozieren kann (Behrens et al. 1996; Bilic et al. 2007). Dort bindet $\beta$-Catenin an Transkriptionsfaktoren der transcription factor/ lymphoid enbancer binding factor (TCF/LEF)-Familie und bewirkt die Transkription spezifischer Gene, in deren Promotoroder Enhancerregionen entsprechende Nukleotidsequenzen zugänglich sind (Arce et al. 2006; Archbold et al. 2012).

LEF-1 ist ein Mitglied der TCF/LEF-Familie und wurde zuerst in prä-B- und T-Zellen als Aktivator des T-Zell-Rezeptor-Enhancers beschrieben (Waterman und Jones 1990; Travis et al. 1991; Reya et al. 2000). Darüber spielt es hinaus eine wichtige Rolle in der Entwicklung und Organogenese (Clevers 2006). So zeigen homozygot LEF-1-defiziente Mäuse einen komplexen Phänotyp mit fehlender Körperbehaarung, fehlenden Brustdüsen und fehlerhafter Zahnanlage (van Genderen et al. 1994). LEF-1 ist an der Regulation einer Vielzahl von Genen beteiligt, darunter für den Zellzyklus essenzielle Faktoren wie Cyclin D1 (CCND1), C-MYC (MYC) und C-JUN (JUN) (Shitashige et al. 2008)

Neben diesen physiologischen Funktionen wurde der kanonische Wnt-Signalweg schon bald nach seiner Entdeckung mit malignen Erkrankungen assoziiert. Das Protein Adenomatous polyposis coli (APC), ein Bestandteil des Degradationskomplexes, war bereits vor der Entdeckung seiner Funktion im Wnt-Signalweg als Tumorsuppressor beschrieben worden (Groden et al. 1991) und ist in etwa 85 Prozent aller kolorektalen Karzinome mutiert (Kinzler und Vogelstein 1996). Mittlerweile sind so gut wie alle beteiligten Proteine des Wnt-Signalwegs mit der Karzinogenese verschiedenster Entitäten, vor allem der des kolorektalen Karzinoms, assoziiert (Polakis 2007; Klaus und Birchmeier 2008). Mutationen in den Proteinen des $\beta$ Catenin-Destruktionskomplexes können dessen Funktion einschränken, sodass die Signalübertragung über $\beta$-Catenin ungehindert stattfinden kann (Polakis 2012). Dies kann zum Beispiel im Fall von Brustkrebs über die dauerhafte Aktivierung von Zellzyklus-regulierenden Genen wie CCND1 zu einer ungehemmten Zellteilung führen (Lin et al. 2000), was einen essenziellen Schritt für die Kanzerogenese darstellt (Hanahan und Weinberg 2000).

Auch LEF-1 wurde schon früh mit maligner Transformation in Verbindung gebracht, zuerst im kolorektalen Karzinom (Korinek et al. 1997), später auch in hämatologischen Erkrankungen. Wie oben beschrieben, ist LEF-1 zum Beispiel in der CLL dereguliert (Lu et al. 2004). LEF-1 kann nach neuen Daten in schwierigen Fällen sogar zur Diagnosestellung der CLL herangezogen werden, da es eine hohe Spezifität für diese Krankheit aufweist (Menter et al. 2015). Auch in anderen Lymphomen wie dem Mantelzell-Lymphom ist der kanonische 
Wnt-Signalweg konstitutiv aktiv und steuert dort Zellwachstum und verhindert Apoptose (Gelebart et al. 2008). Für das Hodgkin-Lymphom fehlten hingegen zu Beginn dieser Doktorarbeit jegliche Daten zur Relevanz des Wnt-Signalweges.

\subsection{Klinische Aspekte und Therapieansätze des Hodgkin-Lymphoms}

Klinisch äußert sich das Hodgkin-Lymphom meist in einer supradiaphragmalen Lymphadenopathie, vor allem im cervicalen oder supraclaviculären Bereich. B-Symptome wie Gewichtsverlust, Nachtschweiß sowie unerklärbares Fieber, das undulierend verlaufen kann, sind in etwa einem Drittel der Fälle zu beobachten. Weitere mögliche Symptome können eine Splenomegalie sowie eine unspezifische Erhöhung von Entzündungsparametern sein (Herold 2014).

Zur Sicherung der Verdachtsdiagnose Hodgkin-Lymphom wird eine Exstirpation des vergrößerten Lymphknotens durchgeführt, eine Feinnadelbiopsie ist aufgrund der eingeschränkten Beurteilbarkeit der Lymphknotenarchitektur wenn möglich zu vermeiden (Ansell 2014). Im mikroskopischen Präparat kann die Diagnose Hodgkin-Lymphom durch den Nachweis CD30-positiver HRS-Zellen in Verbindung mit der typischen histologischen Struktur gestellt werden (Ansell 2014).

Zur Komplettierung des klinischen Stagings erfolgt neben der histologischen Sicherung eine Computertomographie mit Kontrastmittel von Hals bis Becken sowie eine Sonographie des Abdomens, um weitere suspekte Herde zu identifizieren. Weiterhin sollte eine Knochenmarkspunktion durchgeführt werden, um einen möglichen Befall auszuschließen (Ansell 2014). Auf Grundlage der klinisch-pathologischen Befunde wird das Krankheitsstadium von HL-Patienten nach der Ann-Arbor-Klassifikation bestimmt (Carbone et al. 1971).

Die Therapie des cHL sollte in allen Stadien primär mit einem kurativen Ansatz erfolgen, da auch fortgeschrittene Stadien in der Regel gut auf eine Chemotherapie ansprechen. Grundsätzlich werden frühe und intermediäre Stadien mit einer kombinierten Radiochemotherapie behandelt, während fortgeschrittene Stadien nur mit hochdosierter Chemotherapie behandelt werden (Ansell 2014). Die 10-Jahres-Überlebensrate von Patienten mit fortgeschrittenen Tumorstadien liegt abhängig vom Chemotherapie-Regimen bei 75 bis 85 Prozent (Engert et al. 2009).

Da das Hodgkin-Lymphom zu einem großen Teil sehr junge Patienten betrifft, stellen die langfristigen Nebenwirkungen einer solchen aggressiven Therapie ein großes Problem dar. Vor allem die intensive Chemotherapie nach dem BEACOPP-Schema (Akronym für die 
verwendeten Chemotherapeutika Bleomycin, Etoposid, Adriamycin, Cyclophosphamid, Vincristin, Procarbazin und Prednisolon) geht mit einer hohen Belastung einher und kann das Risiko für Zweit-Malignome, wie akute Leukämien, erhöhen (Engert et al. 2009; LeMieux et al. 2015). Daher sollte das Ziel der Therapie eine hohe Effektivität bei möglichst niedriger Toxizität sein (Diefenbach und Steidl 2013). Außerdem stellen primär disseminierte sowie rezidivierte Hodgkin-Lymphome eine Herausforderung dar (Montanari und Diefenbach 2014). Die Rezidivtherapie des Hodgkin-Lymphoms ist weniger gut durch Studien untermauert und besteht in den meisten Fällen aus einer Hochdosis-Chemotherapie mit anschließender autologer Stammzelltransplantation, womit bei etwa 50 Prozent der Patienten ein dauerhaftes Ansprechen erreicht werden kann (Schmitz et al. 2002; Montanari und Diefenbach 2014).

Ein neuer Ansatz könnte in diesen Situationen der Einsatz einer sogenannten targeted therapy, einer selektiv nur gegen die Tumorzellen gerichteten Therapie, sein. Für die Therapie des Hodgkin-Lymphoms wurde ein Antikörper-Wirkstoff-Konjugat vorgestellt, bei dem ein gegen CD30 gerichteter Antikörper mit einem Spindelgift kombiniert wurde und welches auf diese Weise selektiv HL-Zellen abtötet (Younes et al. 2010). Trotz dieser und weiterer vielversprechender Therapiemöglichkeiten des Hodgkin-Lymphoms können heute noch immer 50 Prozent der Patienten mit einem Rezidiv nicht geheilt werden (Montanari und Diefenbach 2014).

\subsection{Vorergebnisse der Arbeitsgruppe}

In vorherigen Arbeiten dieser Arbeitsgruppe konnte gezeigt werden, dass der Transkriptionsfaktor LEF-1 im Burkitt-Lymphom aberrant exprimiert wird (Walther et al. 2013). Eine Deregulation des kanonischen Wnt-Signalwegs ist darüber hinaus auch für andere hämatologische Malignome wie das Multiple Myelom, das Mantelzelllymphom und die CLL bekannt (Derksen et al. 2004; Gelebart et al. 2008; Gutierrez et al. 2010). Darauf aufbauend stellte sich die Frage, ob eine Relevanz des Wnt-Signalwegs im Hodgkin-Lymphom nachzuweisen sei.

Eine Inhibition der Wnt-Signaltransduktion durch transiente Knockdowns von Frizzled, Dishevelled, $\beta$-Catenin und LEF-1 führte in Vorarbeiten dieser Forschungsgruppe zu einer verminderten Migrationsfähigkeit der HL-Zellen. Auf Basis dieser Erkenntnisse wurden mittels lentiviraler Transduktion stabile LEF-1-Knockdown-Klone der HL-Zelllinie L-428 erstellt, um den Einfluss von LEF-1 auf die HL-Zellen in in vivo-Modellen untersuchen zu können. 
Als Modell für die Untersuchung von HL-Zellen in vivo diente hierbei das Chorion-AllantoisMembran-Modell. Dieses wurde von einer kooperierenden Arbeitsgruppe für den Einsatz als Modell für das Burkitt-Lymphom etabliert und seitdem in dieser Forschungsgruppe verwendet (Klingenberg et al. 2014; Ueberdiek 2016). Zum Einsatz des Modells für die Untersuchung des Hodgkin-Lymphoms lagen zu Beginn dieser Arbeit noch keine publizierten Daten vor, allerdings war der Einsatz innerhalb der Gruppe bereits etabliert. 


\subsection{Fragestellung}

Das Hodgkin-Lymphom kennzeichnet sich besonders durch eine geringe Anzahl von entarteten Tumorzellen und einem sehr viel größeren Infiltrat des Immunsystems um diese Zellen herum. Dies macht eine enge Interaktion der Tumorzellen mit den sie umgebenden Zellen nötig. Deregulierte intrazelluläre Signalwege können ein Mittel der Tumorzellen sein, ihre Umgebung zu beeinflussen. Der Wnt-Signalweg ist in vielen malignen Entitäten dereguliert, allerdings liegen hierzu für das Hodgkin-Lymphom keinerlei Daten vor. Vorarbeiten dieser Arbeitsgruppe wiesen darauf hin, dass der Wnt-Signalweg eine entscheidende Rolle im Disseminationsprozess des Hodgkin-Lymphoms spielen könnte (siehe oben).

In dieser Dissertation sollen folgende Fragen beantwortet werden:

1. Wie verhalten sich HL-Zellen, in denen die LEF-1-Expression dauerhaft gehemmt war?

2. Wie verhalten sich HL-Zellen im CAM-Assay?

3. Wie wirkt sich eine reduzierte LEF-1-Expression in HL-Zellen auf die Tumorentwicklung im CAM-Assay aus?

4. Ist eine aberrante LEF-1-Expression für die Interaktion von HL-Zellen mit Endothelzellen verantwortlich?

Zur Beantwortung der ersten Frage werden charakterisierende in vitro-Versuche mit den erstellten Zelllinien durchgeführt. Die zweite und dritte Fragestellung wird mittels des in der Arbeitsgruppe etablierten Modells der Chorion-Allantois-Membran von Hühnereiern untersucht. Hierbei soll das Verhalten von Hodgkin-Lymphomzellen in ovo geprüft werden, dazu werden neben der Beobachtung und Beschreibung der entstehenden Tumoren licht- und fluoreszenzmikroskopische Verfahren genutzt. Daran anschließend wird im dritten Teil dieser Arbeit untersucht, inwiefern der Transkriptionsfaktor LEF-1 einen Einfluss auf das Verhalten der Tumorzellen im CAM-Modell hat. Dazu werden LEF-1-defiziente Tumorzellen im CAMModell eingesetzt und ihr Verhalten mit den Wildtyp-Tumorzellen verglichen. Abschließend beschäftigt sich diese Arbeit mit der Funktion von LEF-1 im Hodgkin-Lymphom, insbesondere in Bezug auf die Interaktion der Tumorzellen mit Endothelien. Hierfür wird das Verhalten von humanen Endothelzellen in verschiedenen in vitro-Versuchen beobachtet, wenn sie mit dem Überstand von HL-Zellen inkubiert werden.

Diese Arbeiten sollen ein neues Verständnis der Dissemination von HL-Zellen erlauben und langfristig neue therapeutische Optionen eröffnen. 


\section{Material und Methoden}

Im folgenden Materialteil (Kapitel 2.1) sind alle regelmäßig verwendeten Geräte, Substanzen, Versuchstiere und Softwares mit deren Herstellern aufgeführt.

Der Methodenteil (Kapitel 2.2) gliedert sich in zellbiologische Methoden (Kapitel 2.2.1), proteinbiochemische Methoden (Kapitel 2.2.2), CAM-Assay (Kapitel 2.2.3) und statistische Analysen (Kapitel 2.2.4)

\subsection{Material}

\subsubsection{Geräte}

Tabelle 1: Verwendete Geräte.

\begin{tabular}{|c|c|}
\hline Gerät & Hersteller \\
\hline 48-Well Chemotaxis Chamber (Boyden-Kammer) & Neuro Probe Inc., Gaitherburg, MD, USA \\
\hline Accu Jet & Brand GmbH \& Co. KG, Wertheim, Deutschland \\
\hline Bioruptor Standard Sonication Device & Diagenode Inc., Denville, NJ, USA \\
\hline BSS 300 GTFS Brutgerät & Grumbach Brutgeräte GmbH, Asslar, Deutschland \\
\hline Elektrophoresekammer und Wet-Blot-System & Bio-Rad GmbH, München, Deutschland \\
\hline FACScan Durchflusszytometer & $\begin{array}{l}\text { Becton, Dickinson and Company, Franklin Lakes, } \\
\text { NJ, USA }\end{array}$ \\
\hline Zeiss Imager.Z1 & Carl Zeiss Microscopy Gmbh, Jena, Deutschland \\
\hline Glimmer-Sägeblatt $0,4 \mathrm{~mm}$ & Seipp GmbH, Langgöns, Deutschland \\
\hline Heraeus Multifuge $3 \mathrm{~L}-\mathrm{R}$ & Thermo Fisher Scientific Inc., Waltham, MA, USA \\
\hline HERAfreeze, $-80^{\circ} \mathrm{C}$ Freezer & Thermo Fisher Scientific Inc., Waltham, MA, USA \\
\hline Ikamag RCT Magnetrührer/Heizplatte & IKA-Werke GmbH \& Co. KG, Staufen, Deutschland \\
\hline Infinite F50 & Tecan Group Ltd., Männedorf, Schweiz \\
\hline Inkubator Cytoperm & Thermo Fisher Scientific Inc., Waltham, MA, USA \\
\hline Inverses Durchlichtmikroskop Telaval 31 & Carl Zeiss Microscopy Gmbh, Jena, Deutschland \\
\hline Leica CM3050 S Kryotom & Leica Microsystems GmbH, Wetzlar, Deutschland \\
\hline Leica DFC290 & Leica Microsystems GmbH, Wetzlar, Deutschland \\
\hline Leica DM 5000B & Leica Microsystems GmbH, Wetzlar, Deutschland \\
\hline Leica M 125 & Leica Microsystems GmbH, Wetzlar, Deutschland \\
\hline Leica M205 FA & Leica Microsystems GmbH, Wetzlar, Deutschland \\
\hline Luminescent Image Analyzer LAS-4000 & Fujifilm, Minato, Japan \\
\hline
\end{tabular}




\begin{tabular}{|l|l|}
\hline Gerät & Hersteller \\
\hline Microflow Laminar Downflow Workstation & Bioquell Ltd., Andover, Großbrittanien \\
\hline Microm HM 355 S & Microm International GmbH, Walldorf, Deutschland \\
\hline Zeiss Axiovert 200M & Carl Zeiss Microscopy Gmbh, Jena, Deutschland \\
\hline Zeiss Axiocam MRm & Carl Zeiss Microscopy GmbH, Jena, Deutschland \\
\hline NanoDrop ND-1000 Spectrophotometer & Thermo Fisher Scientific Inc., Waltham, MA, USA \\
\hline Neubauer-Zählkammer & LO Laboroptik GmbH, Friedrichsdorf, Deutschland \\
\hline Pipetboy acu & Integra Biosciences AG, Fernwald, Deutschland \\
\hline Sanyo Ultra Low -152 ${ }^{\circ}$ C Freezer & Panasonic Healthcare Co. Ltd., Tokio, Japan \\
\hline Shandon Citadel 2000 Tissue Processor & Thermo Fisher Scientific Inc., Waltham, MA, USA \\
\hline Shandon Histocentre & Thermo Fisher Scientific Inc., Waltham, MA, USA \\
\hline T3000 Thermocycler & Biometra GmbH, Göttingen, Deutschland \\
\hline Tischzentrifuge 1-15k & $\begin{array}{l}\text { Sigma Laborzentrifugen GmbH, Osterode, } \\
\text { Deutschland }\end{array}$ \\
\hline Varistain 24-4 Automatic Slide Stainer & Thermo Fisher Scientific Inc., Waltham, MA, USA \\
\hline Vortex Genie 2 & Schütt Labortechnik, Göttingen, Deutschand \\
\hline Waage L2200S & Sartorius AG, Göttingen, Deutschland \\
\hline
\end{tabular}

\subsubsection{Verbrauchsmaterialien}

Tabelle 2: Verwendete Verbrauchsmaterialien.

\begin{tabular}{|l|l|}
\hline Verbrauchsmaterial & Hersteller \\
\hline 96-Well-Platte (Rund-/Flachboden) & Sarstedt AG \& Co., Nümbrecht, Deutschland \\
\hline Cellstar Tissue Culture Dishes & $\begin{array}{l}\text { Greiner Bio-One International GmbH, } \\
\text { Kremsmünster, Österreich }\end{array}$ \\
\hline Cryo.s Einfriergefäße & $\begin{array}{l}\text { Greiner Bio-One International GmbH, } \\
\text { Kremsmünster, Österreich }\end{array}$ \\
\hline Deckgläser & Menzel, Braunschweig, Deutschland \\
\hline Einbettformen aus Metall & Carl Roth GmbH, Karlsruhe, Deutschland \\
\hline Falcon Röhrchen (15 ml, 50 ml) & Sarstedt AG \& Co., Nümbrecht, Deutschland \\
\hline Filter Tips (10 $\mu$ l, $100 \mu l, 1000 \mu l)$ & Sarstedt AG \& Co., Nümbrecht, Deutschland \\
\hline Inkubationsflaschen mit abnehmbaren Deckel & Sarstedt AG \& Co., Nümbrecht, Deutschland \\
\hline Immobilon PVDF Membrane Advantages & Merck Millipore, Darmstadt, Deutschland \\
\hline Nunc Petrischale & Thermo Fisher Scientific Inc., Waltham, MA, USA \\
\hline Objektträger Super Frost & Thermo Fisher Scientific Inc., Waltham, MA, USA \\
\hline Pasteur-Plast Pipetten, steril & Brand GmbH \& Co. KG, Wertheim, Deutschland \\
\hline Polycarbonat-Membran $8 \mu \mathrm{m}$ & Neuro Probe, Gaitherburg, MD, USA \\
\hline
\end{tabular}




\begin{tabular}{|l|l|}
\hline Verbrauchsmaterial & Hersteller \\
\hline Polystyrene Round-Bottom Tube $5 \mathrm{ml}$ & Becton Dickinson, Franklin Lakes, NJ, USA \\
\hline Reaktionsgefäße $(0,5 \mathrm{ml}, 1,5 \mathrm{ml}, 2 \mathrm{ml})$ & Eppendorf, Hamburg, Deutschland \\
\hline Rotilabo-Einbettkassetten & Carl Roth GmbH, Karlsruhe, Deutschland \\
\hline $\begin{array}{l}\text { Specific Pathogen Free Eggs, Hühnereier frei von } \\
\text { spezifischen Pathogenen }\end{array}$ & $\begin{array}{l}\text { Valo BioMedia GmbH, Osterholz-Scharmbeck, } \\
\text { Deutschland }\end{array}$ \\
\hline Serologische Pipetten (5 ml, $10 \mathrm{ml}, 25 \mathrm{ml})$ & Sarstedt AG \& Co., Nümbrecht, Deutschland \\
\hline $\begin{array}{l}\text { Whatman-Filterpapier (Diethylaminoethyl-Zellulose) } \\
\text { Zellkulturflaschen mit Belüftungskappe }\left(25 \mathrm{~cm}^{2},\right. \\
\left.75 \mathrm{~cm}^{2}, 175 \mathrm{~cm}^{2}\right) \text { für Suspensions-/adhärente Zellen }\end{array}$ & GE Healthcare Bio-Sciences, Pittsburgh, PA, USA \\
\hline
\end{tabular}

\subsubsection{Chemikalien}

Tabelle 3: Verwendete Chemikalien.

\begin{tabular}{|c|c|}
\hline Chemikalien & Hersteller \\
\hline$(\mathrm{D}+)$-Trehalose-Dihydrat & Carl Roth GmbH, Karlsruhe, Deutschland \\
\hline 4-lodphenylborsäure (4-IPBA) & Sigma-Aldrich Corporation, St. Louis, MO, USA \\
\hline Acrylamid/Bisacrylamid $40 \%$ & $\begin{array}{l}\text { Serva Electrophoresis } \mathrm{GmbH} \text {, Heidelberg, Deutsch- } \\
\text { land }\end{array}$ \\
\hline Ammoniumpersulfat (APS) $(10 \%$ in $\mathrm{H} 2 \mathrm{O})$ & Bio-Rad GmbH, München, Deutschland \\
\hline BD Matrigel Matrix, Growth Factor Reduced & $\begin{array}{l}\text { Becton, Dickinson and Company, Franklin Lakes, } \\
\text { NJ, USA }\end{array}$ \\
\hline bovines Serum-Albumin (BSA) & Carl Roth $\mathrm{GmbH}$, Karlsruhe, Deutschland \\
\hline Bromphenolblau & Merck KgaA, Darmstadt, Deutschland \\
\hline Calciumchlorid $\left(\mathrm{CaCl}_{2}\right)$ & Merck KgaA, Darmstadt, Deutschland \\
\hline Complete Proteinaseninhibitor Cocktail Tablets & F. Hoffmann-La Roche Ltd, Basel, Schweiz \\
\hline Corning Matrigel Basement Membrane Matrix & Corning Inc., Tewksbury, MA, USA \\
\hline Desoxyadenosintriphosphat (dATP), $100 \mathrm{mM}$ & PrimeTech ALC, Minsk, Weißrussland \\
\hline Desoxycytidintriphosphat (dCTP), $100 \mathrm{mM}$ & PrimeTech ALC, Minsk, Weißrussland \\
\hline Desoxyguanosintriphosphat (dGTP), $100 \mathrm{mM}$ & PrimeTech ALC, Minsk, Weißrussland \\
\hline Desoxythymidintriphosphat (dTTP), $100 \mathrm{mM}$ & PrimeTech ALC, Minsk, Weißrussland \\
\hline Diethylpyrocarbonat (DEPC) & Carl Roth $\mathrm{GmbH}$, Karlsruhe, Deutschland \\
\hline Dimethylsulfoxid (DMSO) & Sigma-Aldrich Corporation, St. Louis, MO, USA \\
\hline EBM-2 & Lonza Group Ltd., Basel, Schweiz \\
\hline Eosin B & Carl Roth $\mathrm{GmbH}$, Karlsruhe, Deutschland \\
\hline Essigsäure $100 \%$ & Merck KgaA, Darmstadt, Deutschland \\
\hline Ethanol $99 \%$ & J.T. Baker, Center Valley, PA, USA \\
\hline
\end{tabular}




\begin{tabular}{|c|c|}
\hline Chemikalien & Hersteller \\
\hline Ethylendiamintetraacetat (EDTA) & Merck KgaA, Darmstadt, Deutschland \\
\hline Fetales Kälberserum (FCS) & Biochrom, Merck Millipore, Darmstadt, Deutschland \\
\hline Formaldehyd & Sigma-Aldrich Corporation, St. Louis, MO, USA \\
\hline Formaldehyd Lösung $37 \%$ & Merck KgaA, Darmstadt, Deutschland \\
\hline $\begin{array}{l}\text { Full Range Rainbow Molecular Weight Markers RPN } \\
800 \mathrm{E}\end{array}$ & GE Healthcare Bio-Sciences, Pittsburgh, PA, USA \\
\hline Giemsa Stammlösung & Carl Roth GmbH, Karlsruhe, Deutschland \\
\hline Glycin & Carl Roth $\mathrm{GmbH}$, Karlsruhe, Deutschland \\
\hline Hämatoxylin & Carl Roth GmbH, Karlsruhe, Deutschland \\
\hline Hämatoxylin & Sigma-Aldrich Corporation, St. Louis, MO, USA \\
\hline Hot FIREPol DNA-Polymerase, Hotstart & Solis BioDyne OÜ, Tartu, Estland \\
\hline Isopropanol & J.T. Baker, Center Valley, PA, USA \\
\hline Kaliumchlorid (KCl) & Carl Roth $\mathrm{GmbH}$, Karlsruhe, Deutschland \\
\hline Kaliumdihydrogenphosphat $\left(\mathrm{KH}_{2} \mathrm{PO}_{4}\right)$ & Carl Roth $\mathrm{GmbH}$, Karlsruhe, Deutschland \\
\hline Kollagen Typ I, 5 mg/ ml & Trevigen Inc., Gaithersburg, MD, USA \\
\hline Kupfersulfat $\left(\mathrm{CuSO}_{4}\right)$ & Sigma-Aldrich Corporation, St. Louis, MO, USA \\
\hline Luminol & Sigma-Aldrich Corporation, St. Louis, MO, USA \\
\hline Magnesiumchlorid $\left(\mathrm{MgCl}_{2}\right)$ & Solis BioDyne OÜ, Tartu, Estland \\
\hline Mayers Hämalaun Lösung & Merck KgaA, Darmstadt, Deutschland \\
\hline Methanol $99 \%$ & $\begin{array}{l}\text { Th. Geyer GmbH \& Co.KG, Renningen, Deutsch- } \\
\text { land }\end{array}$ \\
\hline Milchpulver & Carl Roth GmbH, Karlsruhe, Deutschland \\
\hline Natriumchlorid ( $\mathrm{NaCl})$ & Merck KgaA, Darmstadt, Deutschland \\
\hline Natrium-Desoxycholat & Merck KgaA, Darmstadt, Deutschland \\
\hline Natriumdihydrogenphosphat $\left(\mathrm{NaH}_{2} \mathrm{PO}_{4}\right)$ & Carl Roth $\mathrm{GmbH}$, Karlsruhe, Deutschland \\
\hline Natriumdodecylsulfat (SDS) & $\begin{array}{l}\text { Serva Electrophoresis } \mathrm{GmbH} \text {, Heidelberg, Deutsch- } \\
\text { land }\end{array}$ \\
\hline NP-40 Igepal (Nonidet P-40) & Sigma-Aldrich Corporation, St. Louis, MO, USA \\
\hline Paraformaldehyd & Carl Roth GmbH, Karlsruhe, Deutschland \\
\hline Paraplast Plus & Sigma-Aldrich Corporation, St. Louis, MO, USA \\
\hline Penicillin/Streptomycin (P/S) & Lonza Group Ltd., Basel, Schweiz \\
\hline Phenylmethylsulfonylfluorid (PMSF) & Sigma-Aldrich Corporation, St. Louis, MO, USA \\
\hline Phosphat gepufferte Salzlösung (PBS) & Pan-Biotech GmbH, Aidenbach, Deutschland \\
\hline Phos-Stop & F. Hoffmann-La Roche Ltd, Basel, Schweiz \\
\hline Pikrinsäure & Merck KgaA, Darmstadt, Deutschland \\
\hline Polyfreeze Tissue Freezing Medium & Polysciences, Inc., Warrington, PA, USA \\
\hline
\end{tabular}




\begin{tabular}{|c|c|}
\hline Chemikalien & Hersteller \\
\hline $\begin{array}{l}\text { Ponceau S-Lösung }(0,1 \% \text { Ponceau S in } 5 \% \text { Essig- } \\
\text { säure) }\end{array}$ & Sigma-Aldrich Corporation, St. Louis, MO, USA \\
\hline Puromycin & InvivoGen, San Diego, CA, USA \\
\hline Random Hexamer Primer & IBA Lifesciences GmbH, Göttingen, Deutschland \\
\hline ReBlot Plus Mild & Merck Millipore, Darmstadt, Deutschland \\
\hline Roti-Histokit II & Carl Roth $\mathrm{GmbH}$, Karlsruhe, Deutschland \\
\hline Roti-Histokitt II & Carl Roth $\mathrm{GmbH}$, Karlsruhe, Deutschland \\
\hline Roti-Load (4x Probenpuffer) & Carl Roth $\mathrm{GmbH}$, Karlsruhe, Deutschland \\
\hline Roti-Quant & Carl Roth GmbH, Karlsruhe, Deutschland \\
\hline RPMI-1640 mit L-Glutamin & Lonza Group Ltd., Basel, Schweiz \\
\hline Saccharose & Carl Roth $\mathrm{GmbH}$, Karlsruhe, Deutschland \\
\hline SYBR Green I Nukleinsäure Gelfärbung, 1:100 & F. Hoffmann-La Roche Ltd, Basel, Schweiz \\
\hline Tetramethylethylendiamine (TEMED) & Sigma-Aldrich Corporation, St. Louis, MO, USA \\
\hline Trisbase Salzlösung (TBS) & Carl Roth $\mathrm{GmbH}$, Karlsruhe, Deutschland \\
\hline Triton $\times 100$ & Carl Roth GmbH, Karlsruhe, Deutschland \\
\hline Trypanblau $0.4 \%$ in PBS & Sigma-Aldrich Corporation, St. Louis, MO, USA \\
\hline Trypsin / EDTA Solution (10x) & Biochrom, Merck Millipore, Darmstadt, Deutschland \\
\hline Tween-20 (T) & $\begin{array}{l}\text { Serva Electrophoresis GmbH, Heidelberg, Deutsch- } \\
\text { land }\end{array}$ \\
\hline Wasser, HPLC-Grad & J.T. Baker, Center Valley, PA, USA \\
\hline Xylol & Carl Roth $\mathrm{GmbH}$, Karlsruhe, Deutschland \\
\hline
\end{tabular}

\subsubsection{Puffer, Lösungen und Medien}

Tabelle 4: Verwendete Puffer, Lösungen und Medien.

\begin{tabular}{|l|l|}
\hline Puffer / Lösung / Ansatz & Zutaten \\
\hline $10 \%$ Trenngel & $\begin{array}{l}10 \% \text { Acrylamid/Bis Solution } \\
250 \mathrm{mM} \text { Trisbase } \mathrm{pH} 8,8 \\
0,0004 \% \mathrm{APS} \\
0,00125 \% \text { TEMED }\end{array}$ \\
\hline 4 SDS-Probenpuffer & $\begin{array}{l}500 \mu \text { l Roti-Load } 1 \text { (4x) } \\
1 \% \text { gesättigte Bromphenolblau-Lösung }\end{array}$ \\
\hline $5 \%$ Sammelgel & $\begin{array}{l}5 \% \text { Acrylamid/Bis Solution } \\
250 \mathrm{mM} \text { Tris-Base pH 6,8 } \\
0,0004 \% \text { APS } \\
0,00125 \% \text { TEMED }\end{array}$ \\
\hline
\end{tabular}




\begin{tabular}{|c|c|}
\hline Puffer / Lösung / Ansatz & Zutaten \\
\hline Blockierlösung I & $5 \%$ BSA in TBS-T 0,1\% \\
\hline Blockierlösung II & $5 \%$ Milchpulver in TBS-T 0,1 \% \\
\hline Bouin-Fixanz (wässriges Bouin) & $\begin{array}{l}\text { Pikrinsäure } \\
10 \% \text { Formaldehyd } \\
5 \% \text { Essigsäure }\end{array}$ \\
\hline cDNA-Master Mix (pro Probe) & $\begin{array}{l}4 \mu \mathrm{l} 5 \mathrm{x} \text { first strand buffer } \\
2 \mu \mathrm{l} 0,1 \mathrm{M} \text { Dithiothreitol (DTT) } \\
1 \mu \mathrm{l} \text { SuperScript II reverse Transkriptase } \\
1 \mu \mathrm{l} 10 \mathrm{mM} \text { dNTPs }\end{array}$ \\
\hline Einfriermedium & $\begin{array}{l}90 \% \text { FCS } \\
10 \% \text { DMSO }\end{array}$ \\
\hline Karnovsky-Fixierlösung & $\begin{array}{l}\text { 0,3 M Sörensen-Puffer } \\
3 \% \text { Paraformaldehyd } \\
3 \% \text { Glutaraldehyd }\end{array}$ \\
\hline Laufpuffer (10x) für Western Blot & $\begin{array}{l}250 \text { mM Tris } \\
1,92 \text { M Glycin } \\
1 \% \text { SDS }\end{array}$ \\
\hline Lockelösung & $\begin{array}{l}161,32 \mathrm{mM} \mathrm{NaCl} \\
5.64 \mathrm{mM} \mathrm{KCl} \\
2.14 \mathrm{mM} \mathrm{CaCl}_{2}\end{array}$ \\
\hline NP-40 Lysepuffer & $\begin{array}{l}50 \mathrm{mM} \text { Tris-Base } \mathrm{pH} 7,4 \\
150 \mathrm{mM} \mathrm{NaCl} \\
1 \mathrm{mM} \text { EDTA } \\
0,5 \% \text { NP-40 }\end{array}$ \\
\hline Mayer's Hämalaun-Lösung & $\begin{array}{l}1 \mathrm{~g} \text { Hämalaun } \\
1000 \mathrm{ml} \text { Aqua bidest. } \\
0,2 \mathrm{~g} \mathrm{NaJO} 3 \\
50 \mathrm{~g} \text { Kalialaun } \\
50 \mathrm{~g} \text { Chloraldydrat } \\
1 \mathrm{~g} \text { Zitronensäure }\end{array}$ \\
\hline Luminol-Lösung (ECL-Lösung Teil I) & $\begin{array}{l}100 \mathrm{mM} \text { Tris/HCl pH 8,8 } \\
2,5 \mathrm{mM} \text { Luminol } \\
4 \mathrm{mM} \text { 4-IPBA }\end{array}$ \\
\hline Peroxid-Lösung (ECL-Lösung Teil II) & $\begin{array}{l}100 \mathrm{mM} \text { Tris/HCl pH 8,8 } \\
10,6 \mathrm{mM} \mathrm{H}_{2} \mathrm{O}_{2}\end{array}$ \\
\hline Sörensen-Puffer & $\begin{array}{l}54,6 \mathrm{mM} \mathrm{KH}_{2} \mathrm{PO}_{4} \\
245,4 \mathrm{mM} \mathrm{Na}_{2} \mathrm{HPO}_{4}\end{array}$ \\
\hline
\end{tabular}




\begin{tabular}{|c|c|}
\hline Puffer / Lösung / Ansatz & Zutaten \\
\hline \multirow[t]{2}{*}{ SYBR-Green-Mix (für qRT-PCR) } & $3 \mathrm{mM} \mathrm{MgCl} 2$ \\
\hline & 1:80.000 SYBR-Green I \\
\hline \multirow[t]{8}{*}{ (Ansatz für 2.500 Proben) } & 75 mM Tris- $\mathrm{HCl}$ pH 8,8 \\
\hline & $20 \mathrm{mM}\left(\mathrm{NH}_{4}\right)_{2} \mathrm{SO}_{4}$ \\
\hline & 0,2 mM dNTP-Mix \\
\hline & 0,01\% Tween-20 \\
\hline & $20 \mathrm{U} / \mathrm{ml}$ Hot FIREPol DNA-Polymerase \\
\hline & $0,25 \%$ Triton X-100 \\
\hline & ad $6,5 \mathrm{ml} \mathrm{H} \mathrm{H}_{2} \mathrm{O}$ mit $0,1 \%$ DEPC \\
\hline & 7,5 ml 1M Trehalose \\
\hline \multirow[t]{2}{*}{ TBS $(1 \mathrm{x})$} & 20 mM Tris-Base $\mathrm{pH}$ 7,6 \\
\hline & 137 mM NaCl pH 7,6 \\
\hline \multirow[t]{2}{*}{ TBS-T } & 1xTBS pH 7,6 \\
\hline & $0,1 \%$ Tween-20 \\
\hline \multirow[t]{3}{*}{ Transferpuffer (1x) } & 2,5 mM Tris-Base $\mathrm{pH} 8,3$ \\
\hline & 192 mM Glycin \\
\hline & $15 \%$ Methanol \\
\hline Trypanblau-Lösung & 0,4 \% Trypanblau in PBS \\
\hline \multirow[t]{3}{*}{ Zellkulturmedium I (für HL-Zelllinien) } & RPMI-1640 mit 4 mM L-Glutamin \\
\hline & $10 \%$ FCS HL \\
\hline & $1 \%$ Penicillin/Streptomycin \\
\hline \multirow[t]{3}{*}{$\begin{array}{l}\text { Zellkulturmedium II (für transduzierte, Puromycin- } \\
\text { resistente Zellen) }\end{array}$} & $\begin{array}{l}\text { RPMI-1640 mit 4mM L-Glutamin } \\
10 \% \text { FCS HL }\end{array}$ \\
\hline & $1 \%$ Penicillin/Streptomycin \\
\hline & $2 \mu \mathrm{g} / \mathrm{ml}$ Puromycin \\
\hline \multirow[t]{10}{*}{ Zellkulturmedium III (für HUVECs) } & Clonetics EGM-2MV BulletKit \\
\hline & $500 \mathrm{ml}$ EBM-2 Medium \\
\hline & 0,5 ml human Epidermal Growth Factor \\
\hline & 0,5 ml Vascular Endothelial Growth Factor \\
\hline & 0,5 ml R3-Insulin-like Growth Factor-1 \\
\hline & $2 \mathrm{ml}$ human Fibroblast Growth Factor \\
\hline & 0,5 ml Ascorbinsäure \\
\hline & $0,2 \mathrm{ml}$ Hydrocortison \\
\hline & 0,5 ml Gentamicin/Amphotericin-B \\
\hline & $25 \mathrm{ml} \mathrm{FCS}$ \\
\hline
\end{tabular}




\subsubsection{Antikörper}

Tabelle 5: Verwendete Antikörper mit Angabe der verwendeten Verdünnung.

\begin{tabular}{|l|l|l|}
\hline Antikörper & Verdünnung & Hersteller \\
\hline anti-GAPDH, mouse & $1: 20.000$ in 5\% BSA & $\begin{array}{l}\text { Abcam, Cambridge, } \\
\text { Großbritannien }\end{array}$ \\
\hline anti-LEF-1, rabbit & $1: 1.000$ in 5\% BSA & $\begin{array}{l}\text { CellSignaling, Leiden, } \\
\text { Niederlande }\end{array}$ \\
\hline anti-Mep21, mouse, anti-chicken & $1: 500$ in 5\% BSA & AbLab, Vancouver, Kanada \\
\hline anti-mouse, goat & $1: 2.000$ in 5\% BSA & $\begin{array}{l}\text { Santa Cruz, Heidelberg, } \\
\text { Deutschland }\end{array}$ \\
\hline anti-Prox1, rabbit & $1: 500$ in 5\% BSA & $\begin{array}{l}\text { Reliatech GmbH, Wolfenbüttel, } \\
\text { Deutschland }\end{array}$ \\
\hline anti-rabbit, goat & $1: 2.000$ in 5 $\%$ BSA & $\begin{array}{l}\text { Santa Cruz, Heidelberg, } \\
\text { Deutschland }\end{array}$ \\
\hline anti-VEGFA, mouse & $1: 140$ in PBS & $\begin{array}{l}\text { Reliatech GmbH, Wolfenbüttel, } \\
\text { Deutschland }\end{array}$ \\
\hline
\end{tabular}

\subsubsection{Zelllinien}

Tabelle 6: Verwendete Zelllinien.

\begin{tabular}{|l|l|}
\hline Zelllinie & Referenz \\
\hline HUVEC & $\begin{array}{l}\text { Primärzellen, Lonza Group Ltd., Basel, Schweiz } \\
\text { (freundlicherweise überlassen von Prof. Dr. Wilting, } \\
\text { Zentrum Anatomie, Göttingen) }\end{array}$ \\
\hline L-428 & (Schaadt et al. 1979) \\
\hline
\end{tabular}

\subsubsection{Oligonukleotide}

Tabelle 7: Verwendete Oligonukleotidsequenzen. Es sind die Primersequenzen für die Amplifikation der genannten Zielgene in der quantitativen Reverse-Transkriptase-PCR augeführt. Alle Primer wurden von IBA Lifesciences $\mathrm{GmbH}$, Göttingen hergestellt.

\begin{tabular}{|l|l|}
\hline Zielgen & Primersequenz \\
\hline ABL & $\begin{array}{l}\text { fwd: 5' AGC CTG GCC TAC AAC AAG TTC TC 3' } \\
\text { rev: 5' GAC ATG CCA TAG GTA GCA ATT TCC 3' }\end{array}$ \\
\hline LEF-1 & $\begin{array}{l}\text { fwd: 5' TAA TGC ACG TGA AGC CTC AGC 3' } \\
\text { rev: 5' TTA ATG TGA GGT CTT TTT GGC TCC 3' }\end{array}$ \\
\hline VEGFA & $\begin{array}{l}\text { fwd: 5'ATT ATG CGG ATC AAA CCT CAC C 3‘ } \\
\text { rev: 5'GGT CTG CAT TCA CAT TTG TTG TG 3' }\end{array}$ \\
\hline
\end{tabular}




\subsubsection{Software}

Tabelle 8: Verwendete Software.

\begin{tabular}{|l|l|}
\hline Software & Hersteller \\
\hline Adobe Photoshop CS2.1 & Adobe Systems Inc., San José, CA, USA \\
\hline Graph Pad Prism 6.05 for Windows & Graph Pad Software Inc., San Diego, USA \\
\hline Image J 1.48v & $\begin{array}{l}\text { Wayne Rasband, National Institutes of Health, } \\
\text { Bethesda, MD, USA }\end{array}$ \\
\hline Leica Application Suite 3.8.0 & Leica Microsystems, Wetzlar, Deutschland \\
\hline $\begin{array}{l}\text { Leica Application Suite Advanced } \\
\text { Fluorescence 3.2.0.9632 }\end{array}$ & \begin{tabular}{l} 
Leica Microsystems, Wetzlar, Deutschland \\
\hline Magellan for F50 7.0
\end{tabular} \\
\hline Microsoft Office 2010 (Word, Powerpoint, Excel) & Tecan Group Ltd., Männedorf, Schweiz \\
\hline NIS Elements F 2.20 & Microsoft, Redmont, WA, USA \\
\hline RQ Manager 1.2.1 & $\begin{array}{l}\text { Applied Biosystems, Thermo Fisher Scientific Inc., } \\
\text { Waltham, MA, USA }\end{array}$ \\
\hline Sequence Detection System SDS 2.4 & $\begin{array}{l}\text { Applied Biosystems, Thermo Fisher Scientific Inc., } \\
\text { Waltham, MA, USA }\end{array}$ \\
\hline Zeiss Axiovision 3.1 & \begin{tabular}{l} 
Carl Zeiss Microscopy GmbH, Jena, Deutschland \\
\hline Ceiss Axiovision 4.6.3
\end{tabular} \\
\hline
\end{tabular}

\subsection{Methoden}

\subsubsection{Zellbiologische Methoden}

\subsubsection{Hodgkin-Lymphom-Zelllinie}

Als Modell für das Hodgkin-Lymphom diente in dieser Arbeit die Zelllinie L-428, diese wurde 1978 aus einer pleuralen Effusion einer 38-jährigen Patientin mit Hodgkin-Lymphom, Stadium IVb, isoliert (Schaadt et al. 1979). Von zwei unabhängigen Chargen der HodgkinLymphom-Zelllinie L-428 wurden an unterschiedlichen Zeitpunkten lentivirale Transduktionen durchgeführt, die dabei etablierten Subklone wurden mit A und B bezeichnet (Näheres dazu siehe Kapitel 2.2.1.2). Alle Suspensionszelllinien wurden mit einer Konzentration von $5 \cdot 10^{5}$ Zellen $/ \mathrm{ml}$ in Medium kultiviert. Nach 48 Stunden wurde regelmäßig die Zellzahl mit Hilfe einer Neubauer-Zählkammer bestimmt und die Zielkonzentration durch Zugabe einer entsprechenden Menge Medium wiederhergestellt. Jeweils vor und nach dem Wochenende wurden die Zellen bei $120 \mathrm{~g}$ und Raumtemperatur für sieben Minuten zentrifugiert. Der Überstand wurde mit Hilfe einer Absaugpumpe durch eine Pasteurpipette 
abgesaugt und das Pellet in einer entsprechenden Menge Medium resuspendiert. Alle Zelllinien wurden 24 Stunden vor geplanten Versuchen auf ihre Zielkonzentration eingestellt und mussten am Versuchstag eine Viabilität von mindestens 95 Prozent aufweisen, um verwendet zu werden.

\subsubsection{Stabiler LEF-1-Knockdown}

Von zwei unabhängigen Chargen der Zelllinie L-428 wurden genetisch veränderte Varianten mit LEF-1-Knockdown erstellt. LEF-1-defiziente L-428-Zellen, die aus zwei unabhängigen lentiviralen Transduktionen etabliert werden konnten, wurden in dieser Arbeit genutzt und entsprechend mit A oder B gekennzeichnet. Neben den Knockdown-Zellen wurden von beiden Transduktionen die parentalen Zellen sowie die ns-Kontroll-Zellen (siehe unten) als Kontrollen mitgeführt.

Durch lentivirale Transduktion der parentalen Zelllinie wurde der pGIPZ-Vektor stabil in das Genom der Zielzellen eingebaut. So wurde permanent eine unter dem starken Cytomegalievirus-Promotor (CMV-Promotor) gelegene, gegen LEF-1 gerichtete small hairpin RNA (shRNA) abgelesen. Diese shRNA bewirkt die Degradation der LEF-1-mRNA, resultierend in einer Defizienz des Proteins LEF-1. Zusätzlich zu den LEF-1-defizienten Zellklonen wurden non-silencing-Kontrollen eingesetzt, bei denen die shRNA-Sequenz gegen keine bekannte humane mRNA der Zelle gerichtet war. Weiterhin enthält der pGIPZ-Vektor als Selektionsmarker eine Resistenz gegen das Antibiotikum Puromycin. Puromycin verhindert die Bindung von Aminoacyl-tRNA an das Ribosom und wirkt somit durch Termination der Translation toxisch auf eukaryonte Zellen. Die transduzierte Resistenz ermöglichte die Selektion der genetisch modifizierten Zellen in einem Puromycin-haltigen Medium, das heißt nur erfolgreich transduzierte Zellen konnten in diesem toxischen Medium überleben.

Des Weiteren exprimierten die transduzierten Zellen GFP (Green Fluorescent Protein), welches über ein internal ribosome entry site-Element (IRES-Element) mit der shRNA-Sequenz verbunden ist und unter dem gleichen Promotor wie diese liegt. Daher konnte davon ausgegangen werden, dass bei einer Expression von GFP auch eine Expression der shRNA stattfand. Anhand der GFP-Expression wurden die transduzierten Zellen im Durchflusszytometer sortiert und nur die hoch exprimierenden Zellen für Versuche genutzt. Die GFP-Expression wurde in der Durchflusszytometrie sowie unter dem Fluoreszenzmikroskop in regelmäßigen Abständen nachgewiesen und kontrolliert 


\subsubsection{Endothelzellen}

Die Zelllinie HUVEC (buman umbilical vein endothelial cell), welche aus der Nabelschnurvene eines menschlichen Föten stammt, diente als Modellzelllinie für das Verhalten von BlutEndothelzellen.

Die adhärent wachsenden HUVECs wurden in hochadhärenten Zellkulturflaschen kultiviert, alle 48 Stunden wurde das Medium (Medium III) gewechselt, dieses wurde in einer Menge von $1 \mathrm{ml} / 6 \mathrm{~cm}^{2}$ eingesetzt. Ab einer Konfluenz von 90 Prozent wurden die Zellen in einem Verhältnis von 1:2 oder 1:3 geteilt und neu ausgesät. Hierzu wurde das Medium abgesaugt, die Zellen mit $10 \mathrm{ml}$ PBS-Puffer einmal gespült und anschließend mit $1 \mathrm{ml}$ Trypsin/Ethylendiamintetraacetat (EDTA) pro $25 \mathrm{~cm}^{2}$ Bodenfläche abgelöst. Nach zwei- bis dreiminütiger Inkubation bei $37^{\circ} \mathrm{C}$ war erfolgreiche Ablösung mikroskopisch zu erkennen, die Zellen wurden dann in der doppelten Menge Medium III resuspendiert und für 5 min bei $200 \mathrm{~g}$ sedimentiert und anschließend in einer neuen Zellkulturflasche mit einer Dichte von 6.000 Zellen $/ \mathrm{ml} / 6 \mathrm{~cm}^{2}$ ausgesät. Versuche mit den HUVEC-Endothelzellen wurden maximal bis Passage 6 durchgeführt.

\subsubsection{Zellzahl- und Viabilitätsbestimmung}

Die Suspensionszellen wurden alle 48 Stunden aus dem Inkubator entnommen und sowohl makroskopisch als auch mikroskopisch beurteilt. Unter der Sicherheitswerkbank wurde die Zellsuspension dann gemischt und ein kleines Aliquot entnommen. Dieses wurde mit einer Trypanblau-Lösung im Verhältnis 1:1 vermischt und anschließend in eine NeubauerZählkammer aufgetragen. Der Farbstoff Trypanblau kann ausschließlich in abgestorbene Zellen gelangen, gesunde Zellen durchdringt er nicht. Durch diese Methode konnte zusätzlich zur Zellzahl auch die Viabilität der Zelllinie (Anteil lebender Zellen relativ zur Gesamtzellzahl) bestimmt werden.

Für die adhärenten Endothelzellen wurde prinzipiell gleich verfahren, allerdings mussten die Zellen zuvor, wie bereits beschrieben, mit Trypsin/EDTA vom Flaschenboden abgelöst werden. 


\subsubsection{Gefrierkonservierung und Auftauen der Zelllinien}

Für die Gefrierkonservierung der Zelllinien wurden $5 \cdot 10^{6}$ Zellen in $1 \mathrm{ml}$ Einfriermedium (90\% FCS + 10\% Dimethylsulfoxid) resuspendiert, in spezielle Kryotubes verbracht und anschließend mit Hilfe von mit Isopropanol gefüllten Einfrierboxen langsam $\left(1^{\circ} \mathrm{C} / \mathrm{min}\right)$ auf $-80{ }^{\circ} \mathrm{C}$ heruntergekühlt. Zur Langzeitlagerung wurden die Zellen bei $-150{ }^{\circ} \mathrm{C}$ gefrierkonserviert.

Um gefrierkonservierte Lymphomzellen wieder in Kultur zu nehmen wurden die Kryotubes schnell in einem $37^{\circ} \mathrm{C}$ warmen Wasserbad aufgetaut und anschließend in $9 \mathrm{ml}$ warmes Medium überführt. Diese Suspension wurde bei $120 \mathrm{~g}$ für $7 \mathrm{~min}$ zentrifugiert, der Überstand wurde abgesaugt und die Zellen wurden in $5 \mathrm{ml}$ Medium resuspendiert, in eine Zellkulturflasche überführt und über Nacht im Brutschrank inkubiert. Am nächsten Morgen wurde die Zellzahl bestimmt, die Zellen wurden erneut zentrifugiert und auf die Zielkonzentration eingestellt.

Für Endothelzellen wurde ein sehr ähnliches Verfahren verwandt, allerdings wurden die Zellen nach der Zentrifugation in einer entsprechenden Menge Medium $\left(6.000\right.$ Zellen $\left./ \mathrm{ml} / 6 \mathrm{~cm}^{2}\right)$ resuspendiert und in einer Zellkulturflasche mit adhärentem Boden ausgesät. Nach 24 Stunden wurden die Zellen einmal mit $10 \mathrm{ml}$ warmen PBS gewaschen und das Medium III erneuert.

\subsubsection{Bestimmung der Zellteilungsrate}

Zur Bestimmung der Zellteilungsrate wurden $4 \cdot 10^{6}$ Zellen jeder Zelllinie in $8 \mathrm{ml}$ Medium I resuspendiert und bei $37^{\circ} \mathrm{C}$ inkubiert. Nach 24, 48 und 72 Stunden wurde jeweils ein kleines Aliquot entnommen und die Zellzahl mit Hilfe der Neubauer-Zählkammer bestimmt.

\subsubsection{Durchflusszytometrie}

Die Durchflusszytometrie wurde als Methode zur Analyse verschiedener molekularer und physikalischer Eigenschaften der Zellen eingesetzt. Im Durchflusszytometer werden die Zellen vereinzelt und mit hoher Geschwindigkeit an verschiedenen Lasern vorbeigeführt, was zur Emission von Licht seitens der Zelle führt. Die Streuung des reflektierten Lichts nach vorne hängt vom Volumen der Zelle ab und erlaubt damit einen Rückschluss auf die Größe der Zelle (FSC, forward scatter), die Streuung im rechten Winkel hängt von der Granularität der Zelle ab und kann somit zur Unterscheidung von Zelltypen dienen (SSC, sideward scatter). Die gemessenen Werte können in einem Dot Plot gegeneinander aufgetragen werden und somit verschiedene Zellpopulationen unterschieden werden. 
Weiterhin erlaubt die Durchflusszytometrie die Untersuchung von Fluoreszenz, die von den Zellen ausgeht. Es wurde der Fluoreszenzfarbstoff Propidiumiodid eingesetzt, der die Zellmembran von lebenden Zellen nicht durchdringen kann, allerdings die von toten Zellen. Dort interkaliert er in die DNA und emittiert rotes Fluoreszenzlicht, welches vom Durchflusszytometer erkannt wird und auf diese Weise eine Viabilitätsbestimmung erlaubt. Da die transduzierten Zelllinien nach erfolgreichem Einbau des Vektors außerdem ein GFP exprimierten, konnte auch diese grüne Fluoreszenz erfasst werden und somit einen weiteren Nachweis für die gelungene Transduktion liefern.

Für die Messungen im Durchflusszytometer wurden 2,5·10 Zellen in 0,5 ml PBS eingesetzt, hinzu wurden $5 \mu$ l Propidiumiodid gegeben.

\subsubsection{Herstellung von konditionierten Medien (CM)}

Um konditionierte Medien der Lymphomzellen zu erhalten, wurden 1,5·10 Zellen aus der Suspension entnommen, zentrifugiert und anschließend auf eine Konzentration von $5 \cdot 10^{5}$ Zellen $/ \mathrm{ml}$ eingestellt und in eine 6-Well-Platte überführt. Lentiviral transduzierte Zelllinien wurden zuvor zwei Passagen, das heißt zweimal für je 48 Stunden, in Medium I kultiviert.

Nach 48 Stunden wurde die Zellsuspension aus der Well-Platte entnommen und zentrifugiert. Der zellfreie Überstand (konditioniertes Medium) wurde für Versuche verwendet oder bei $-20{ }^{\circ} \mathrm{C}$ gelagert.

\subsubsection{Herstellung von Trockenpellets}

Um Trockenpellets zu erhalten, wurden $2 \cdot 10^{6}$ Zellen aus der Suspension entnommen, bei $4{ }^{\circ} \mathrm{C}$ zentrifugiert und mit $1 \mathrm{ml}$ kaltem PBS gewaschen. Der Überstand wurde abgenommen und das Pellet bei $-20^{\circ} \mathrm{C}$, sofern danach die Bestimmung von Proteinen erfolgen sollte, bzw. bei $-80{ }^{\circ} \mathrm{C}$, wenn RNA isoliert werden sollte, gefrierkonserviert. Lentiviral transduzierte Zelllinien wurden zuvor zwei Passagen in Medium I kultiviert.

\subsubsection{Migrationsanalysen unter Verwendung der Boyden-Kammer}

In der Boyden-Kammer wurde die Migrationsfähigkeit von HUVEC-Endothelzellen auf unterschiedliche chemotaktische Reize untersucht. Die Boyden-Kammer besteht aus zwei Hälften mit je 48 Vertiefungen, die durch eine perforierte Polycarbonat-Membran voneinander getrennt sind.

Konditionierte Medien der HL-Zelllinien (siehe Kapitel 2.2.1.8) wurden in die Vertiefungen der unteren Kammer pipettiert. Der nicht für den Versuch verwendete Teil des 
konditionierten Mediums wurde bei $13.000 \mathrm{~g}$ für $10 \mathrm{~min}$ erneut zentrifugiert und der Überstand in ein weiteres Reaktionsgefäß überführt und bei $-20^{\circ} \mathrm{C}$ gefrierkonserviert.

Die für den Versuch verwendeten Polycarbonat-Membranen hatten Porengrößen von $8 \mu \mathrm{m}$ und wurden kurz vor dem Versuch mit Kollagen Typ I beschichtet. Dazu wurde das Kollagen mit einer Konzentration von $0,5 \mathrm{mg} / \mathrm{ml}$ in $0,1 \mathrm{M}$ Essigsäure gelöst und die Membran mehrmals durch diese Lösung gezogen und anschließend getrocknet. Sie wurde dann nach der Befüllung der unteren Kammer luftblasenfrei auf diese gelegt, wobei der Meniskus der befüllten Wells die Membran punktuell befeuchtete. Die obere Kammer wurde schließlich fest mit der unteren verschraubt.

Zur Migrationsanalyse wurden 5·10 $4^{4}$ Endothelzellen, suspendiert in RPMI 1640, pro Vertiefung in die obere Kammer eingesetzt. Die Zellen mussten innerhalb von vier Stunden durch die $8 \mu \mathrm{m}$ großen Poren der zuvor mit Kollagen Typ I beschichteten Membran migrieren, um schließlich auf der Unterseite der Membran zu adhärieren.

Nach der vierstündigen Inkubationszeit wurde die Flüssigkeit aus den oberen Vertiefungen abgesaugt und die Kammer auseinandergeschraubt. Die Oberseite der Membran wurde dann mit Hilfe einer Klammer und einer Pinzette an einer scharfen Kante unter Zug abgeschabt, damit lediglich die migrierten Zellen der Unterseite angefärbt würden. Zur Fixierung wurde die Membran für 30 min in $4 \%$ Paraformaldehyd inkubiert und anschließend getrocknet. Nach einer dreißigminütigen Färbung in Giemsa-Lösung und zweimaligem Waschen wurde die Membran erneut getrocknet, mittig zerteilt und mit je $100 \mu$ l Roti-Histokitt auf zwei Objektträgern fixiert und mit einem Deckgläschen überdeckt.

Über Nacht wurde die Membran getrocknet, um anschließend ausgewertet werden zu können. Hierzu wurden am Mikroskop unter 200-facher Vergrößerung von jeder Bedingung 18 Fotos (3 pro Vertiefung) gemacht und anschließend am PC mit dem Programm ImageJ ausgezählt. Die Werte pro Vertiefung wurden gemittelt, somit ergaben sich sechs Werte pro Bedingung. Die Werte der ns-Kontrolle wurden als Referenz gleich eins gesetzt und die anderen Bedingungen darauf bezogen.

\subsubsection{Scratch-Assay}

Im Scratch-Assay wurde die durch unterschiedliche Reize initiierte Wundheilungsfähigkeit von Endothelzellen untersucht. Die HUVECs wurden in einer 6-Well-Platte ausgesät und bis zu einer Konfluenz von größer als 95 Prozent kultiviert. Dann wurde mit einer kleinen Pipettenspitze ein komplett durch das Well laufender Scratch, also ein Kratzer, gesetzt. Zur 
Entfernung von Zelltrümmern wurde mit PBS gewaschen, anschließend wurden die Wells mit $2 \mathrm{ml}$ folgender Medien überdeckt:

- Medium III (Positivkontrolle)

- RPMI 1640 (Negativkontrolle)

- konditioniertes Medium der parentalen Zelllinie (L-428 A/L-428 B)

- konditioniertes Medium der ns-Kontrolle

- konditioniertes Medium der LEF-1-defizienten Zelllinien

Der Vorgang der Wundschließung wurde zu Beginn und zum Ende des Versuches fotografisch dokumentiert. Sofort nach Setzen der Wunde wurde ein Bild der Anfangsbreite des Kratzers gemacht und der Ort des Fotos im Well markiert. Nach einer in Vorversuchen bestimmten Zeit von 16 Stunden wurde die Inkubation abgebrochen. Alle Bedingungen wurden zu diesem Zeitpunkt fotografiert, die verbleibende Breite der Wunde mit ImageJ ausgemessen und auf die Anfangsbreite bezogen.

\subsubsection{Proteinbiochemische Methoden}

\subsubsection{Zelllysate}

Zur Herstellung von Proteinlysaten wurde ein Trockenpellet (siehe Kapitel 2.2.1.8) aufgetaut und in $250 \mu \mathrm{l} \mathrm{NP40-Lysepuffer} \mathrm{resuspendiert.} \mathrm{Nach} \mathrm{einer} \mathrm{fünfzehnminütigen} \mathrm{Inkubation} \mathrm{auf}$ Eis folgte die Sonifizierung der Proben für dreimal fünf Sekunden. (Bioruptor: high power, Dauer 10 Sekunden) Anschließend wurde das Lysat 30 Minuten bei $13.000 \mathrm{~g}$ und $4{ }^{\circ} \mathrm{C}$ zentrifugiert und der Überstand in ein neues Reaktionsgefäß überführt.

\subsubsection{Bradford-Messung}

Die Bestimmung der Proteinkonzentration des Zelllysats erfolgte mit Hilfe der photometrischen Methode nach Bradford (Bradford 1976). Hierbei wird die Bindung des Farbstoffs Coomassie-Brilliant-Blau an bestimmte Aminosäure-Seitenketten und die damit verbundene Verschiebung des Absorptionsmaximums genutzt. In ungebundener Form hat der Farbstoff ein Absorptionsmaximum bei 470 nm, nach Komplexbindung an Aminosäuren verschiebt sich dieses auf $595 \mathrm{~nm}$. Da die Extinktion im Photometer linear abhängig von der Proteinkonzentration der Probe ist, kann die Messung mit der farbstoffhaltigen Lösung (RotiQuant) durch eine Standardverdünnungsreihe $[0 \mu \mathrm{g} / \mathrm{ml}-100 \mu \mathrm{g} / \mathrm{ml}]$ von bovinem Serumalbumin kalibriert werden.

Die zu testenden Zelllysate wurden im Verhältnis 1:40 mit Wasser vorverdünnt und anschließend im Verhältnis 1:5 mit der farbstoffhaltigen Lösung versetzt. Nach einer 
fünfminütigen Inkubation wurde die Extinktion bei $595 \mathrm{~nm}$ photometrisch bestimmt. Anhand der Standardverdünnungsreihe konnte die Proteinkonzentration der Zelllysate genau bestimmt werden.

\subsubsection{Western Blot}

Die Immunoblot-Analyse, auch Western Blot genannt, wurde als Methode zum Proteinnachweis verwendet. Sie besteht aus einer Sodiumdodecylsulfat-PolyacrylamidGelelektrophorese (SDS-PAGE) mit anschließender Überführung der aufgetrennten Proteinbanden auf eine Polyvinylidenfluorid-Membran (PVDF-Membran), auf welcher dann Proteine durch die spezifische Bindung von Antikörpern nachgewiesen werden können (Laemmli 1970).

\section{Probenvorbereitung}

Die Zelllysate, deren Proteinkonzentration zuvor in der Bradford-Messung bestimmt wurde, wurden mit 4x SDS-Ladepuffer auf eine Konzentration von $1 \mu \mathrm{g}$ Protein/ $\mu$ l eingestellt und für 10 Minuten bei $95^{\circ} \mathrm{C}$ aufgekocht.

\section{$\underline{\text { Gelektrophorese }}$}

Die Gelektrophorese wurde in der Form einer diskontinuierlichen SDS-PAGE durchgeführt. Pro Tasche des Sammelgels wurden $15 \mu \mathrm{g}$ Protein aufgetragen, zusätzlich wurden in einer Tasche $3 \mu \mathrm{l}$ des Full-Range Rainbow-Markers zur Bestimmung der Proteingröße eingesetzt.

\section{$\underline{\text { Transfer }}$}

Die entlang ihrer Größe aufgetrennten Proteine wurden dann in einem elektrophoretischen Verfahren bei 100 Volt und $4{ }^{\circ} \mathrm{C}$ auf eine PVDF-Membran übertragen. Die Membran wurde zur Erhöhung der Sensitivität getrocknet und mit TBS-T rehydriert. Hierauf erfolgte die Blockade der unspezifischen Proteinbindungsstellen mit fünfprozentigem BSA in TBS-T. Es konnte ein gegen das Zielprotein gerichteter Antikörper eingesetzt werden, mit diesem wurde die Membran bei $4{ }^{\circ} \mathrm{C}$ über Nacht unter ständigem Rollen inkubiert. Nach dreimaligem Waschen mit TBS-T konnte am nächsten Tag der gegen den Primärantikörper gerichtete, horse raddish peroxidase (HRP)-gekoppelte Sekundärantikörper eingesetzt werden. Nach einstündiger Inkubationszeit und weiteren Waschschritten konnte die Bindung des Antikörperkonjugats an ein spezifisches Protein über Chemilumineszenz-Messung bestimmt werden.

Zur Darstellung weiterer Proteine wurden die gebundenen Antikörperkonjugate mit Reblot Plus Mild-Lösung entfernt und die Membran erneut mit BSA blockiert. Als Ladekontrolle wurde als konstitutiv exprimiertes Protein GAPDH nachgewiesen. 
Die Western-Blot-Messungen wurden als laufende Kontrolle des LEF-1-Knockdowns in regelmäßigen Abständen durchgeführt.

\subsubsection{Enzyme-linked Immunosorbent Assay (ELISA)}

Die ELISA-Messungen zur Bestimmung der VEGF-A-Konzentration im Überstand der HLZellen wurden von Dr. Herbert A. Weich am Helmholtz-Institut für Infektionsforschung in Braunschweig mit den nach Kapitel 2.2.1.8 erstellten konditionierten Medien durchgeführt.

Bei diesem Prinzip des Sandwich-ELISA band ein gegen VEGF-A gerichteter Antikörper, der sogenannte coating antibody, an die Vertiefungen einer 96-Well-Platte. Nach Blockierung der unspezifischen Proteinbindungsstellen wurden neben einer Standardverdünnungsreihe die verdünnten Proben in die Vertiefungen pipettiert. Dabei band das Antigen, in diesem Falle VEGF-A an die am Boden der Vertiefungen sitzenden Antikörper. Anschließend wurde ein zweiter gegen VEGF-A gerichteter Antikörper hinzugegeben. Eine zugegebene HRP konnte an diesen Detektionsantikörper binden und sorgte für die Blaufärbung des danach zugefügten 3,3',5,5'-Tetramethylbenzidin (TMB). Nach der Zugabe von 0,5 M Schwefelsäure kam es proportional zur enthaltenen Antigenmenge zu einem Farbumschlag des TMB ins Gelbe (Wechsel des Absorptionsmaximums von 650 auf $450 \mathrm{~nm}$ ). Dieser Farbumschlag konnte mittels Photometer quantifiziert werden und mit Hilfe der Standardverdünnungsreihe die VEGF-A-Konzentration der Probe bestimmt werden.

\subsubsection{RNA-Isolierung}

Zur Isolierung der Total-RNA aus einem Trockenpellet (siehe Kapitel 2.2.1.8) wurde das RNA-Isolationskit „Nucleospin RNA II“ (Macherey-Nagel) entsprechend den Herstellerangaben verwendet. Dabei wurde das Zellpellet lysiert und homogenisiert, an eine Silikatmembran gebunden, mehrfach zentrifugiert und mit Desoxyribonukleinase (DNAse) inkubiert. Nach mehreren Waschschritten erfolgte die Elution der isolierten RNA in sterilem Wasser.

Die Konzentrations- und Reinheitsbestimmungen der RNA-Lösung wurden mit einem NanoDrop-Spektralphotometer durchgeführt. Nach dem Lambert-Beer-Gesetz konnte durch die Extinktion transmittierten Lichts in der Lösung die Konzentration bestimmt werden. Im Wellenlängenbereich zwischen 220 und $350 \mathrm{~nm}$ besitzen Nukleinsäuren zudem ein charakteristisches Absorptionsspektrum, welches die Detektion möglicher Verunreinigungen, zum Beispiel durch organische Lösungsmittel oder Proteine, erlaubt. Dazu wurden die Absorptionsquotienten $A_{260} / A_{280}$ sowie $A_{260} / A_{230}$ bestimmt, welche bei nicht verunreinigter RNA zwischen 1,9 und 2,1 liegen. 


\subsubsection{6 cDNA-Umschrift}

Die isolierte RNA wurde anschließend in komplementäre DNA (cDNA, complementary DNA) umgeschrieben. Hierzu wurden $3 \mu \mathrm{g}$ RNA, verdünnt auf $10 \mu \mathrm{l}$, zusammen mit $2 \mu \mathrm{l}$ Random Hexamer-Primern (Konzentration $5 \mu \mathrm{M}$ ) für 10 Minuten bei $70^{\circ} \mathrm{C}$ inkubiert und anschließend auf Eis abgekühlt, was die Bindung der Primer an die RNA ermöglichte. Es wurden dann $8 \mu \mathrm{l}$ cDNA-MasterMix zugegeben und die Lösung mit folgendem Programm inkubiert: $25^{\circ} \mathrm{C}$ für 10 Minuten, $42^{\circ} \mathrm{C}$ für $60 \mathrm{~min}, 65^{\circ} \mathrm{C}$ für $10 \mathrm{~min}$ sowie ein abschließendes Abkühlen bei $4{ }^{\circ} \mathrm{C}$. Die gewonnene cDNA wurde bei $-20{ }^{\circ} \mathrm{C}$ gefrierkonserviert.

\subsubsection{7 quantitative Reverse-Transkriptase-Polymerasekettenreaktion}

Diese Methode diente zur Quantifizierung der Aktivität bestimmter transkribierter Gene in einer Zelle. Aus der isolierten RNA der Zellen wurde analog zu Kapitel 2.2.2.6 cDNA erstellt, welche dann über eine Polymerase-Kettenreaktion (PCR) vervielfältigt wurde.

Es wurde eine zu 10 ng RNA äquivalente Menge cDNA in einem Reaktionsansatz mit 5,6 $\mu \mathrm{l}$ SYBR Green Mix (siehe Kapitel 2.1.4) sowie je 0,3 $\mu \mathrm{mol} / 1$ der beiden Primer eines Zielgens auf $10 \mu \mathrm{l}$ verdünnt und in Triplets in die Vertiefungen einer 384-Well-Platte pipettiert.

Der Fluoreszenzfarbstoff SYBR Green interkaliert während der PCR in die amplifizierte DNA und emittiert fluoreszierendes Licht. Diese Fluoreszenz ist proportional zur Amplifikation der DNA und erlaubt somit die Quantifizierung des DNA-Gehalts einer Lösung. Mit jedem Zyklus der PCR steigt die emittierte Fluoreszenz. Ab einem gewissen Zyklus, dem cycle threshold (CT), übersteigt die emittierte Fluoreszenz erstmals das Hintergrundrauschen der Probe. Je mehr DNA eine Probe enthält, desto eher wird der CT überschritten. Als Negativkontrolle wurde steriles Wasser verwendet. Die erhobenen Daten wurden auf das konstitutiv exprimierte Gen $A B L$ nach folgender Formel normalisiert:

$$
\Delta \mathrm{CT}=\mathrm{CT}_{\text {Zielgen }}-\mathrm{CT}_{A B L}
$$

Zur Auswertung der erhobenen Ergebnisse wurden die Programme SDS 2.4 und RQ-Manager von Applied Biosystems verwendet. Die Ergebnisse der einzelnen Zelllinien wurden relativ zu ihrer jeweiligen ns-Kontrolle angegeben.

\subsubsection{CAM-Assay}

Das CAM-(Chorion-Allantois-Membran)-Assay diente als invivo-Xenograft-Modell für die Tumorentwicklung und -progression. Hierzu wurde die CAM befruchteter, pathogen-freier Hühnereier freigelegt und mit einer definierten Menge Tumorzellen, die in einer 
extrazellulären Matrix gelöst waren, beimpft. Nach vier Tagen Inkubationszeit wurden die Tumoren extrahiert, vermessen und anschließend histologisch ausgewertet.

\subsubsection{1 in ovo-CAM-Assay}

Befruchtete Hühnereier wurden ab dem ersten Tag der Entwicklung unter ständigem Wenden bei $37^{\circ} \mathrm{C}$ und 60 Prozent Luftfeuchtigkeit für drei Tage inkubiert. Am vierten Entwicklungstag wurde mit einer Säge ein etwa $0,75 \mathrm{~cm}^{2}$ großes Loch in die desinfizierte Eischale oberhalb des Dotters gesägt, außerdem wurde die Luftblase des Eis angestochen. Dadurch sank der Dotter mit der CAM innerhalb des Eis ab und die Eihaut konnte ebenfalls entfernt werden. Das Ei mit der nun freiliegenden CAM wurde mit Leukosilk wieder verschlossen und für weitere sieben Tage im Brutschrank inkubiert.

Am elften Tag der Embryonalentwicklung des Huhns konnte die nun schon stark vaskularisierte CAM mit den Tumorzellen in definierten Regionen beimpft werden. Dazu wurden $3 \cdot 10^{6}$ Tumorzellen pro Ei in jeweils $20 \mu \mathrm{l}$ Matrigel, welches aus murinen EngelbrethHolm-Swarm-Sarkomen gewonnen wird, gelöst. Diese Mischung verschiedenster Bestandteile der extrazellulären Matrix erlaubt es den Hodgkin-Lymphomzellen in Form eines soliden Tumors anzuwachsen. Die Beimpfung der CAM mit den Tumorzellen erfolgte in einer Region, die weder zu nahe an einem großen Gefäß noch weitab jeglicher Gefäße war. Nach der Inokulation wurde das Ei erneut verschlossen und wiederum für vier weitere Tage im Brutschrank inkubiert.

Am fünfzehnten Entwicklungstag erfolgte die Extraktion der angewachsenen Tumoren. Dazu wurde das vorhandene Fenster in der Eischale vergrößert und der Tumor und die umgebende CAM großflächig ausgeschnitten. Die Tumoren wurden dann lichtmikroskopisch fotografiert, vermessen und für die weitere histologische Aufbereitung fixiert.

\subsubsection{2 ex ovo-CAM-Assay}

Im Unterschied zum in ovo-CAM-Assay wurden die Hühnerembryonen beim ex ovo-CAMAssay außerhalb der Eischale inkubiert. Dazu wurde am vierten Entwicklungstag die Eischale aufgeschlagen und der komplette Inhalt in eine sterile Schale $(89 \cdot 89 \cdot 25 \mathrm{~mm})$ überführt. Diese wurde in eine mit Kupfersulfat-Lösung befüllte Kulturflasche gestellt und für eine Woche bei $37^{\circ} \mathrm{C}$ inkubiert. Die Inokulation der Tumorzellen erfolgte analog zum in ovo-Versuch, allerdings konnte bei dieser Methode die Lokalisation der Beimpfung in Abhängigkeit von der Gefäßsituation gezielter gewählt werden. Nach der Beimpfung wurden die Tumoren täglich fluoreszenzmikroskopisch untersucht und fotografiert, dies ermöglichte eine genaue Dokumentation des Tumorwachstums und der fortschreitenden Vaskularisierung der Tumoren. 


\subsubsection{Fixierung und histologische Auswertung}

Die Fixierung der entnommenen Tumoren erfolgte durch drei verschiedene Methoden, je nach anschließender Verwendung.

Für eine Hämatoxylin-Eosin-Färbung erfolgte eine dreitägige Fixierung in wässrigem Buoin zur anschließenden Einbettung in Paraffinwachs. Aus den eingebetteten Präparaten wurden mit einem Mikrotom $3 \mu \mathrm{m}$ dicke Schnitte angefertigt und für die nachfolgende Färbung in Hämatoxylin/Eosin auf Objektträger überführt.

Weiterhin erfolgte bei einigen Tumoren der GFP-exprimierenden Zelllinien, also der nsKontrollen und der LEF-1-Knockdown-Zelllinien, eine fluoreszenzerhaltende Fixierung, hierzu wurden die Tumoren nach der Extraktion für 20 Minuten in vierprozentigem Paraformaldehyd (PFA) fixiert, anschließend zweimal in PBS gewaschen und in einer aufsteigenden Saccharose-Reihe inkubiert. Zur Einbettung wurde TissueTek verwendet und die Tumoren bei $-80{ }^{\circ} \mathrm{C}$ über Nacht, danach bei $-20{ }^{\circ} \mathrm{C}$ gelagert (Klingenberg et al. 2014). Die auf diese Weise fixierten Tumoren wurden mit einer Schnittdicke von $12 \mu \mathrm{m}$ im Kryotom geschnitten und sofort bei $-20^{\circ} \mathrm{C}$ im Dunkeln gelagert, um die GFP-vermittelte Fluoreszenz zu erhalten. Die Präparate wurden im Anschluss immunhistochemisch gefärbt. Primärantikörper wurden über Nacht bei $4{ }^{\circ} \mathrm{C}$ eingesetzt, Sekundärantikörper sowie 4',6-Diamidin-2-phenylindol (DAPI) als Kernfärbung für eine Stunde bei Raumtemperatur. Die so gefärbten Präparate konnten dann fluoreszenzmikroskopisch untersucht und ausgewertet werden. Als Antigen zum Nachweis von Blutgefäßen innerhalb des Tumors diente das Protein Myb-Ets-transformed multipotent hematopoietic precursor 21 (Mep21), welches auf Endothelzellen von Vogel-Blutgefäßen exprimiert wird. Zur Detektion von Lymphgefäßen im Tumor diente der selektiv in Lymphendothelzellen exprimierte Transkriptionsfaktor Prospero Homeobox 1 (Prox1). Primärantikörper gegen diese Antigene wurden mit einem rot fluoreszierenden Sekundärantikörper gekoppelt, sodass sich zusammen mit dem blauen Kernfarbstoff DAPI und der Grünfärbung der Tumorzellen durch GFP-Expression ein insgesamt dreifarbiges Bild ergab.

Als dritte Methode diente die Fixierung nach Karnovsky, bei der die Tumoren schon in vivo für 30 min mit Karnovsky-Lösung überdeckt wurden, nach der lichtmikroskopischen Vermessung wurden sie dauerhaft in Karnovsky-Lösung fixiert und in Epoxid-Harz einbettet, was die Anfertigung von Semidünnschnitten erlaubte.

\subsubsection{Einblutungs-Score}

Auf Grundlage der Lichtbilder der Tumoren wurde ein Score zur Bewertung der Vaskularisierung und Einblutungen der Tumoren erstellt. In drei Kategorien konnten jeweils 
bis zu drei Punkte vergeben werden. Beurteilt wurden das Erscheinungsbild der Einblutungen, deren Intensität sowie die relative Größe der eingebluteten Fläche. Die Anwendung des Scores erfolgte verblindet durch eine nicht an den Versuchen beteiligte Person anhand der Lichtbilder der CAM-Versuche. Dargestellt ist eine Übersicht mit beispielhaften Punktwerten für die einzelnen Kategorien (Abbildung 1).

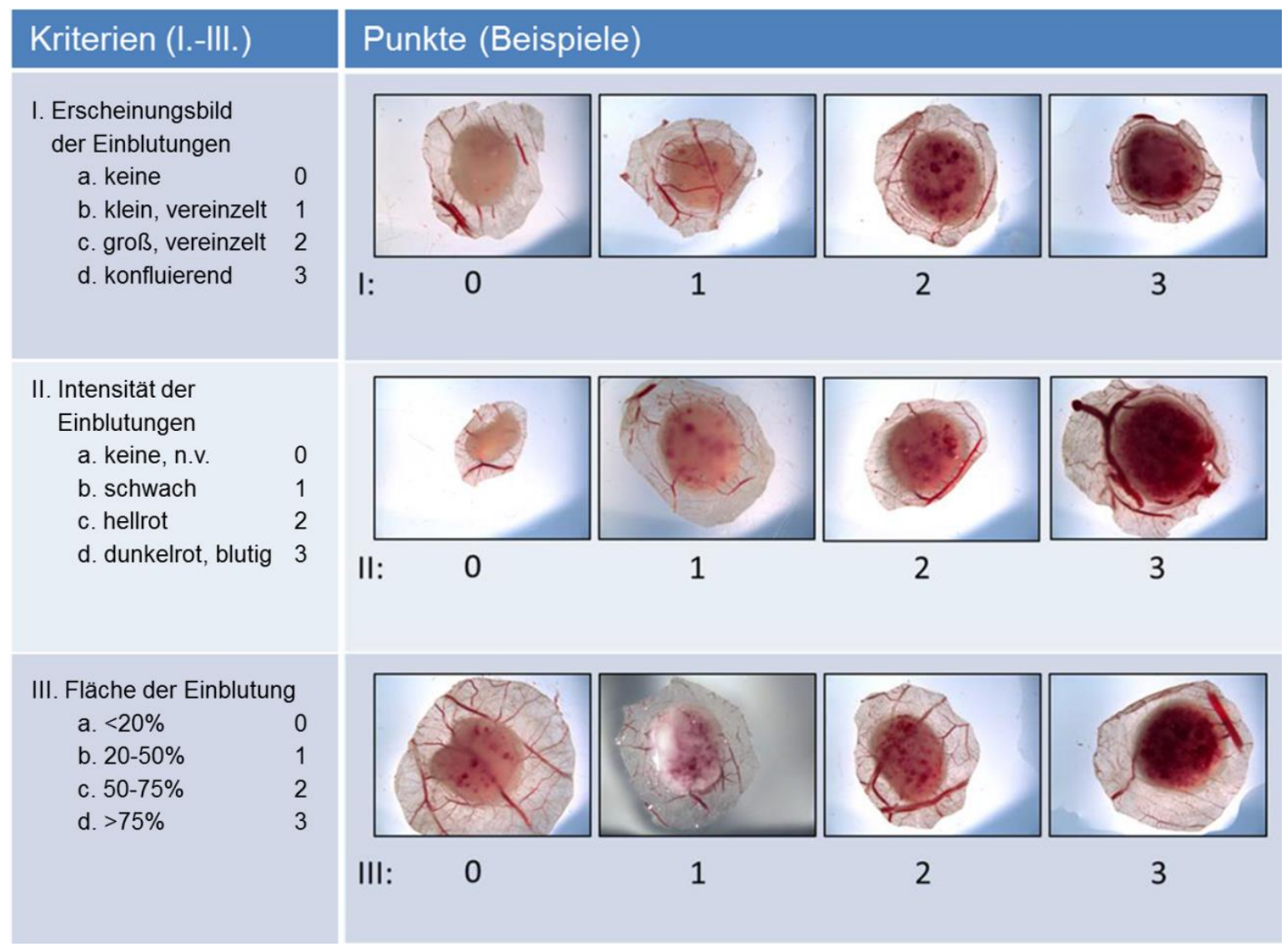

Abbildung 1: Übersichtsbild für die Berechnung des Einblutungs-Scores. Freundlicherweise überlassen von F. Linke.

\subsubsection{Statistische Analysen}

Die Ergebnisse der Versuche wurden dargestellt als Mittelwert \pm Standardabweichung (SD) der angegebenen Anzahl an biologischen Replikaten. Normalverteilung und Varianzgleichheit wurde durch den Kolmogorov-Smirnov-Test bzw. den F-Test geprüft. Normalverteilte Gruppen wurden mit einem one-way-analysis of variance (ANOVA) mit anschließender Bonferroni-Methode untersucht, nicht normalverteilte Gruppen mit einem nichtparametrischen Kruskal-Wallis-Test und Dunnett's Post-Test. Das Signifikanzniveau lag bei ${ }^{*} \mathrm{p}<0,05,{ }^{* *} \mathrm{p}<0.01,{ }^{* * *} \mathrm{p}<0,001$. Für alle statistischen Analysen wurde GraphPad Prism 6.04 verwendet. 


\section{Ergebnisse}

\subsection{Charakterisierung der LEF-1-defizienten HL-Zellen}

In dieser Dissertation wurden stabile LEF-1-Knockdown-Klone der HL-Chargen L-428 A und L-428 B verwendet. Zur Untersuchung der LEF-1-Expression nach der lentiviralen Transduktion wurden die Zelllinien durchflusszytometrisch untersucht. Da das GFP-Gen in dem genutzten pGIPZ-Vektor unter dem gleichen Promotor wie die shRNA liegt und somit in der Zielzelle theoretisch genauso oft transkribiert wird, korreliert die GFP-Expression direkt mit der shRNA-Expression und kann daher als Indikator für eine erfolgreiche Transduktion genutzt werden. Die durchflusszytometrischen Untersuchungen der verwendeten Zelllinien sind in Abbildung 2 dargestellt.

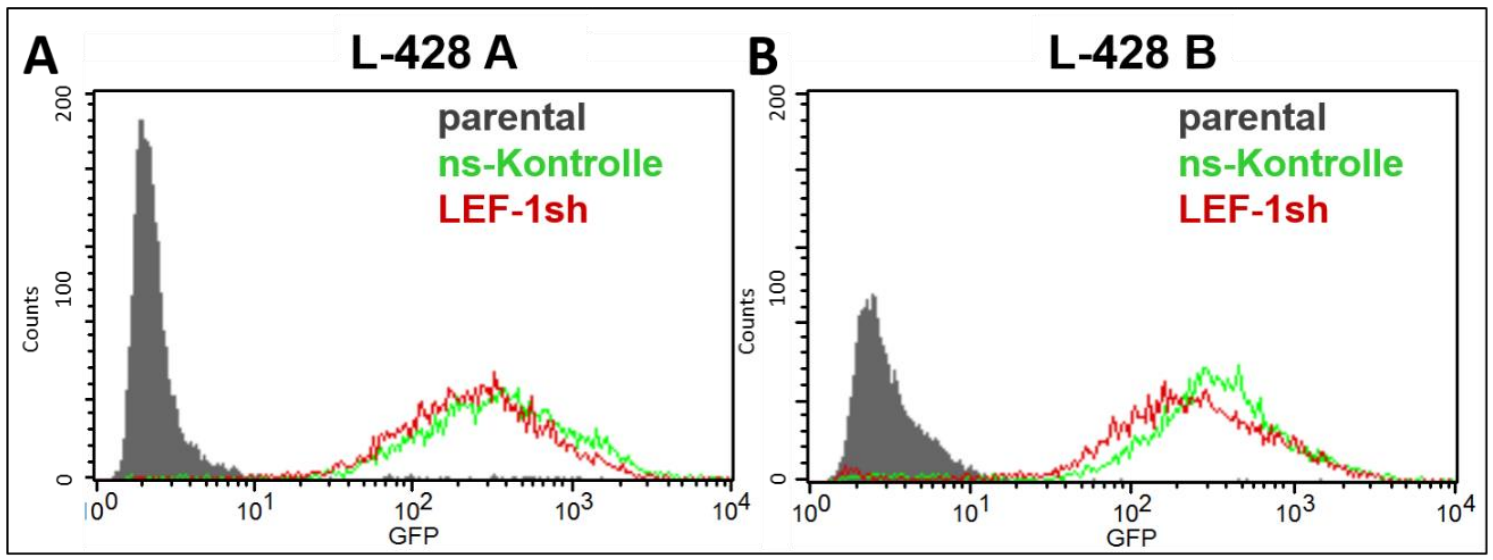

Abbildung 2: Durchflusszytometrische Analyse von HL-Zellen nach Transduktion mit LEF-1sh-RNAund GFP-exprimierenden Lentiviren. Die Zellen wurden im Durchflusszytometer auf ihre GFP-Expression untersucht. Insgesamt wurden 10.000 Zellen pro Zelllinie gezählt. Die Darstellung beinhaltet ein repräsentatives aus drei biologischen Replikaten für die Zellen der Charge L-428 A (A) und der Charge L-428 B (B).

In der Abbildung sind die Zählergebnisse des Durchflusszytometers gegen den GFP-Gehalt der Zellen aufgetragen. Es zeigte sich eine fehlende GFP-Expression der parentalen Zellen, die nicht transduziert wurden und demnach auch kein GFP-Gen tragen. Weiterhin war in den transduzierten Zellen eine weitgehend identische GFP-Expression von ns-Kontrolle und LEF-1-defizienter Linie zu beobachten. Es konnte daher von einem erfolgreichen Einbau des transduzierten Vektors in das Genom beider Zelllinienchargen ausgegangen werden. 


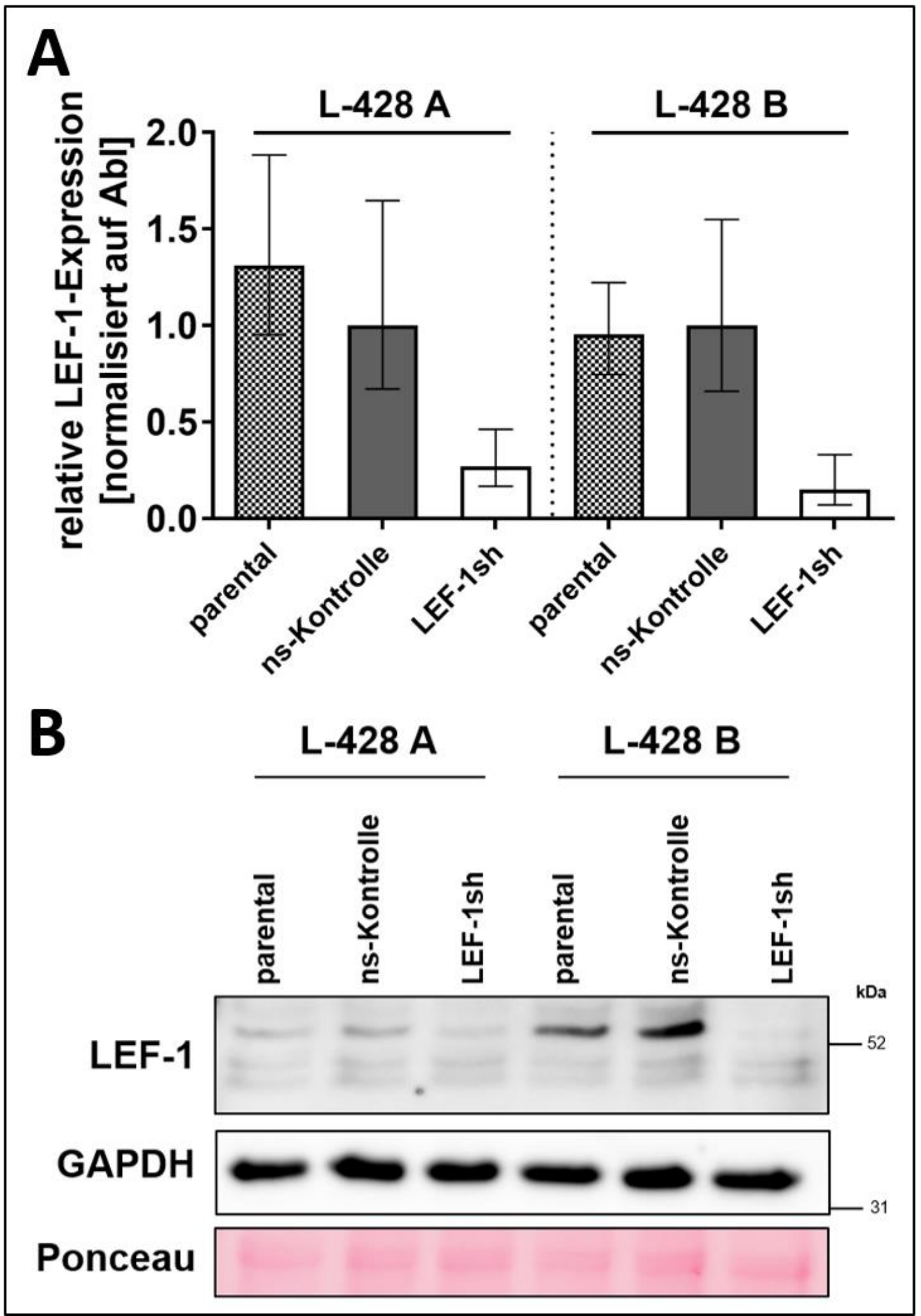

Abbildung 3: Untersuchung der LEF-1-Expression und der LEF-1-Proteinmenge in HL-Zellen nach Expression einer LEF-1shRNA. A. quantitative RT-PCR von Zelllysaten der HL-Zellchargen L-428 A und L-428 B, Angabe der relativen Genexpression von LEF-1, bezogen auf die ns-Kontrolle. Alle Proben wurden auf das konstitutiv exprimierte Gen Abl normalisiert. ( $n=3$, Mittelwert \pm oberer/unterer Grenzwert.)

B. Immunoblotanalyse zum Nachweis der LEF-1-Proteinmenge in L-428-Zellen. In beiden Zelllinienchargen weisen die parentale sowie die ns-Kontrolle eine vergleichbare Proteinmenge an LEF-1 auf, der Knockdown in den LEFsh-Zellen ist deutlich zu erkennen. Als Beladungskontrolle dienten die Proteinfärbung nach Ponceau und das konstitutiv exprimierte Protein GAPDH. Dargestellt ist ein repräsentativer Versuch. 
Zur weiteren Charakterisierung des stabilen LEF-1-Knockdowns wurden die lentiviral transduzierten Zellen sowohl auf transkriptioneller als auch auf translationaler Ebene auf ihre LEF-1-Expression getestet. Durch quantitative RT-PCR wurde die mRNA-Expression und durch Immunoblotanalyse der LEF-1-Proteingehalt bestimmt.

In beiden Zelllinienchargen führte der Knockdown zu einer deutlichen Reduktion der LEF-1mRNA-Expression (Abbildung 3A). Dabei war der Knockdown in der Charge L-428 B mit einer 85-prozentigen Reduktion der Genexpression etwas stärker ausgeprägt als in der Charge L-428 A, wo der Rückgang etwa 74 Prozent betrug. In der Zellliniencharge L-428 B exprimierten sowohl die parentale Kontrolle als auch die ns-Kontrolle eine vergleichbare Menge an LEF-1-mRNA. In der Zellliniencharge L-428 A war eine um etwa 30 Prozent geringere LEF-1-Expression der ns-Kontrolle im Vergleich zur parentalen Zelllinie zu beobachten.

Zum Nachweis der LEF-1-Proteinexpression in den HL-Zelllinien und zur Kontrolle des stabilen Knockdowns wurde eine Immunoblotanalyse der HL-Zelllinien durchgeführt. In der Charge L-428 A exprimieren die parentale sowie die ns-Kontrolle eine vergleichbare Menge LEF-1-Protein, während die entsprechende Bande in der LEF-1-defizienten Zelllinie fast nicht zu erkennen ist (Abbildung 3B). In der Charge L-428 B ist ebenso kein Unterschied in der Bandenintensität der parentalen und der ns-Kontrolle zu erkennen, während die LEF-1Bande der Knockdown-Zelllinie gar nicht vorhanden ist. Weiterhin auffällig ist ein Unterschied der LEF-1-Proteinmenge zwischen den beiden Zelllinienchargen L-428 A und L-428 B, da letztere insgesamt deutlich mehr Menge an LEF-1 aufweist, zu erkennen an der deutlich höheren Intensität des LEF-1-Signals. Aus diesem Grunde wurden die Analysen der beiden LEF-1-defizienten Zelllinienchargen und ihrer Kontrollen im Folgenden auch weiterhin getrennt durchgeführt, ausgewertet und dargestellt.

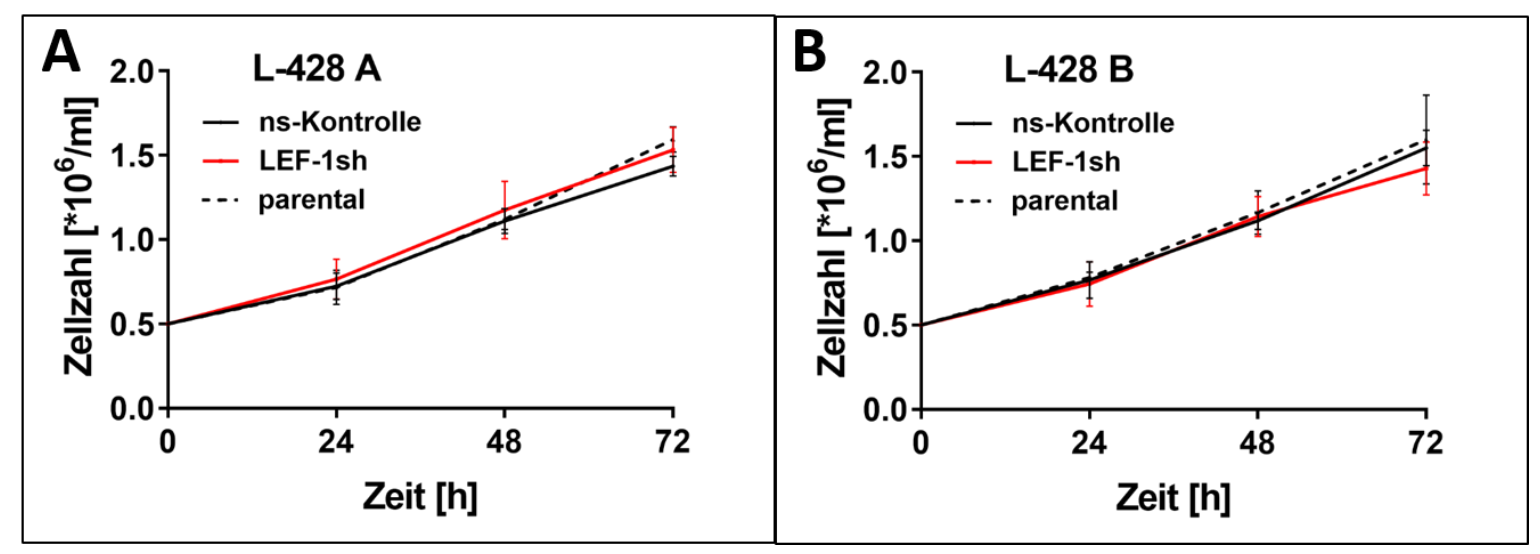

Abbildung 4: Die Zellverdopplung der HL-Zelllinie L-428 ist nicht abhängig von der LEF-1-Expression. $5 \cdot 10^{5}$ Zellen jeder Zellliniencharge wurden in Medium I ausgesät und alle 24 Stunden gezählt. Zu keinem Zeitpunkt lag ein signifikanter Unterschied in den Zellzahlen vor. (Mittelwert \pm Standardabweichung (SD), $n$ $=3$, ANOVA mit Bonferroni-Test) 
Nach dem Nachweis eines erfolgreichen LEF-1-Knockdowns erfolgte eine Untersuchung der Wirkung einer geringeren LEF-1-Expression auf die Zellverdopplung der HL-Zelllinien. Die jeweiligen Zellen wurden in einer Zelldichte von $5 \cdot 10^{5}$ Zellen $/ \mathrm{ml}$ ausgesät und über drei Tage alle 24 Stunden gezählt. Zu keinem Zeitpunkt lag in L-428-Zellen (Abbildung 4) ein Unterschied in der Zellzahl zwischen den jeweiligen Kontrollgruppen und den LEF-1Knockdown-Zellen vor. Daraus ist zu schließen, dass in der HL-Zelllinie L-428 die Proliferation der Tumorzellen unabhängig von LEF-1 stattfindet.

\subsection{Verhalten von HL-Zellen im Xenograft-Modell}

In diesem Abschnitt der Dissertation sind die Ergebnisse der Untersuchungen des Verhaltens von HL-Zelllinien im Xenograft-Modell der Chorion-Allantois-Membran des Hühnereis dargestellt. Zu diesem Zweck wurden L-428-Zellen in Matrigel resuspendiert, auf die CAM appliziert und für 96 Stunden inkubiert.

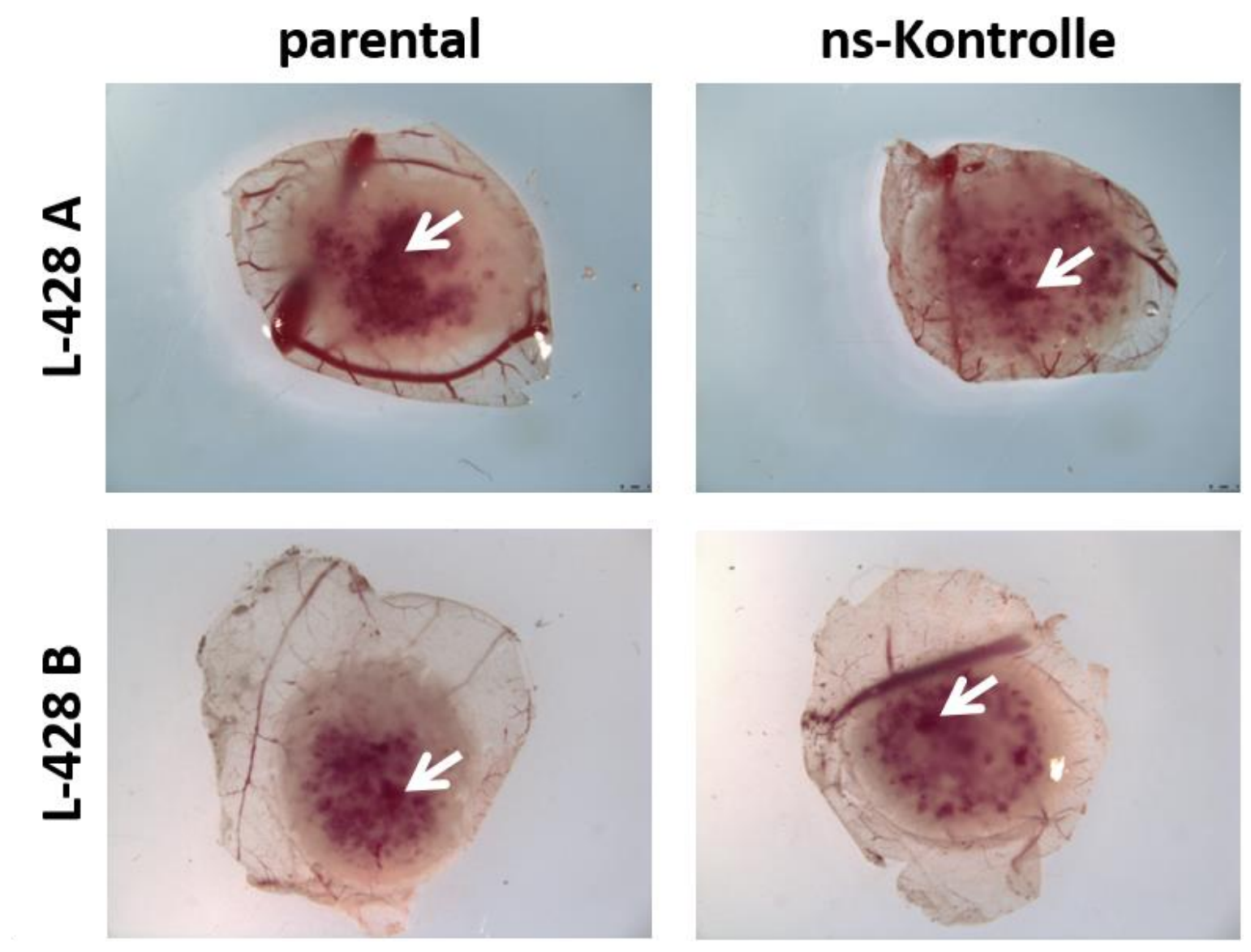

Abbildung 5: Großflächige Einblutungen in Lymphomen der HL-Zelllinien auf der CAM. Lichtmikroskopische Aufnahmen (Vergrößerung 7,82x) von Tumoren der Zelllinie L-428, jeweils mit der parentalen sowie der ns-Kontrolle. Es zeigen sich in allen Tumoren auffällige, teils sehr großflächige Einblutungen in das Tumorgewebe hinein. Besonders auffällige hämorrhagische Zonen sind mit Pfeilen markiert. 
Um weitergehende, fluoreszenzmikroskopische Untersuchungen zu ermöglichen, wurden neben den parentalen Zellen auch die GFP-exprimierenden ns-Kontroll-Zellen verwendet. Die entstandenen Tumoren wurden licht- und fluoreszenzmikroskopisch untersucht, in der Folge fixiert und für eine histologische Weiterbearbeitung aufbereitet. Diese bestand zum einen aus der Anfertigung von Hämatoxylin-Eosin-gefärbten Paraffinschnitten, zum anderen aus der Untersuchung mittels Immunfluoreszenz.

Die entstehenden Tumoren hatten eine flache Form und wiesen makroskopisch meist ausgedehnte hämorrhagische Zonen auf. In Abbildung 5 sind beispielhafte Tumoren beider Zelllinienchargen dargestellt, besonders große Einblutungen sind mit einem Pfeil markiert. Die Form der Einblutungen reichte dabei von kleinen, punktförmigen Einblutungen bis hin zu großen, flächigen Hämorrhagien, die fast den ganzen Tumor betrafen.

Zur weiteren Untersuchung der Tumoren und speziell der hämorrhagischen Zonen wurden die Tumoren für eine histologische Bearbeitung aufbereitet. Es wurden in Paraffin eingebettete, Formalin-fixierte und mit Hämatoxylin-Eosin gefärbte Schnitte angefertigt und licht-mikroskopisch untersucht. Dabei fand sich eindrucksvoll das histologische Korrelat der sichtbaren Einblutungen. Abbildung 6 zeigt beispielhaft den Gang der mikroskopischen Aufarbeitung, mit jeweils einem exemplarischen Tumor der Zellliniencharge L-428 A auf der linken und einem der L-428 B auf der rechten Seite. Beginnend mit der auflichtmikroskopischen Aufnahme in 7,82-facher Vergrößerung, dargestellt in A und B, fielen in beiden ausgewählten Tumoren erneut große Einblutungen auf. Abbildung $\mathbf{6 C}-\mathbf{J}$ stellt weiter ansteigende Vergrößerungen dar, wobei jeweils der mit einem Kasten umrandete Abschnitt in der Abbildung darunter vergrößert gezeigt wird. Rund um viele Gefäße fanden sich Zonen innerhalb des Tumors, die vollständig mit Hühner-Erythrozyten - kleinen, kernhaltigen, roten Zellen - infiltriert waren. Hierbei konnte davon ausgegangen werden, dass die Erythrozyten aus zerstörten oder infiltrierten Kapillaren und Gefäßen in das Gewebe übergetreten waren. Weiterhin waren im Inneren des Tumors keine größeren Gefäße, wie sie in der umgebenden physiologischen CAM vorliegen, mehr zu finden. 

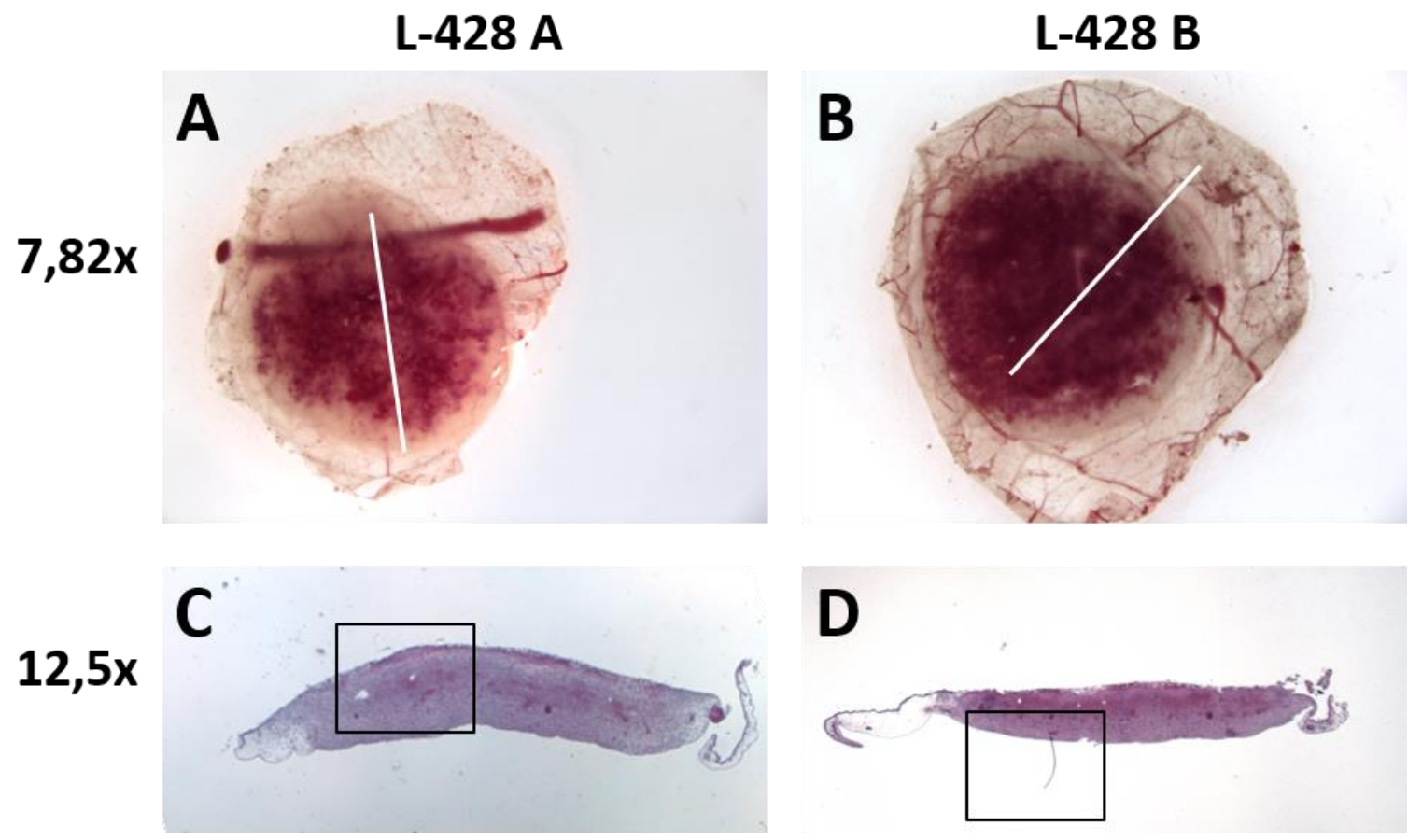

\section{D}
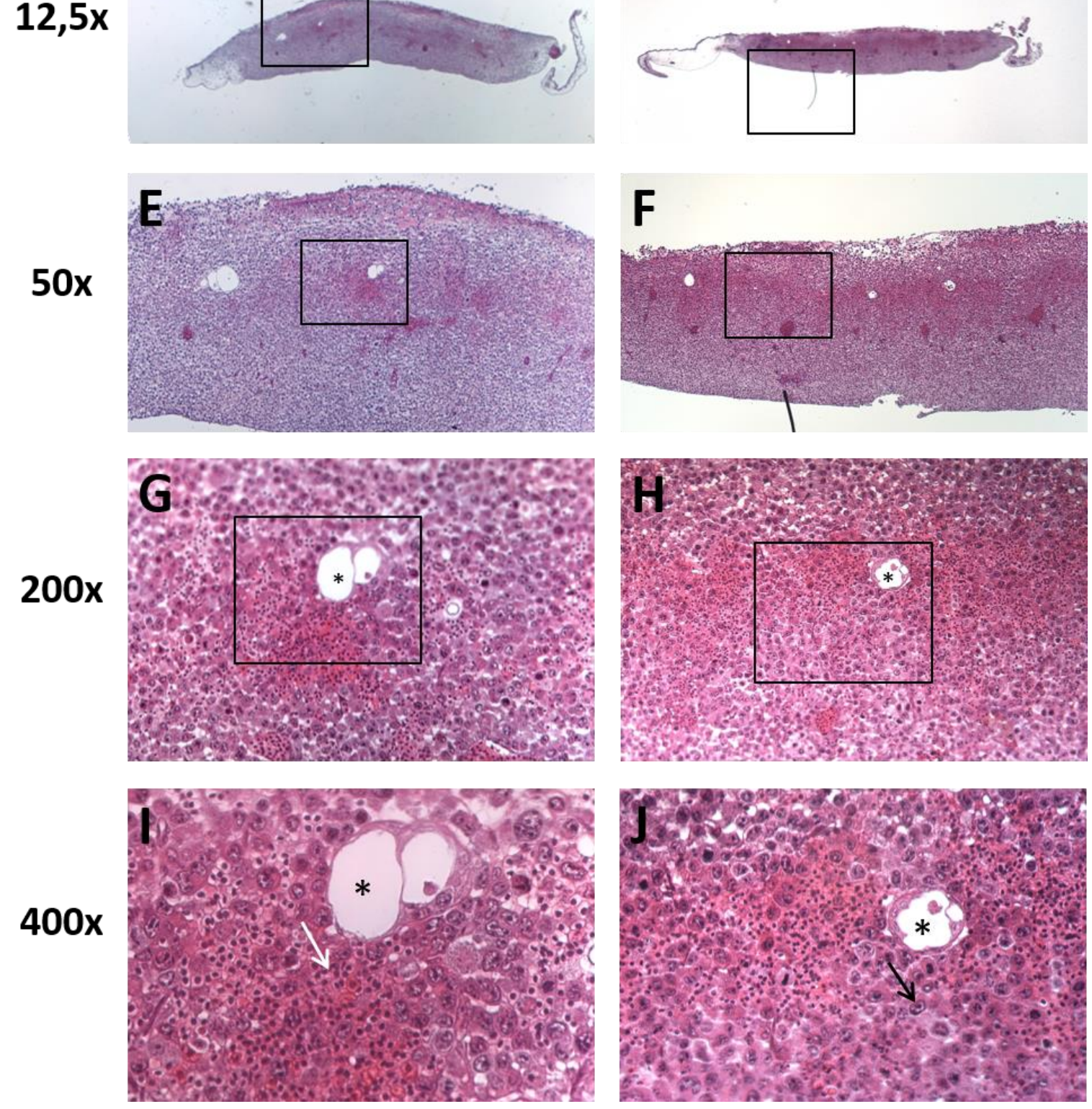

Abbildung 6: Feingewebliche Analysen der Lymphome zeigen großflächige Einblutungen. Gezeigt sind histologische Bilder zweier Tumoren der jeweiligen parentalen L-428-Zellen in aufsteigender Vergrößerung. Die Ebene des histologischen Schnittes ist in A und B mit einer weißen Linie markiert. In G, H, I und J sind Gefäße mit einem Stern (*) bezeichnet. Der weiße Pfeil in I zeigt auf ausgetretene Erythrozyten, der schwarze Pfeil in $\mathrm{J}$ auf eine Tumorzelle. 
In Abbildung 7 ist eine höher aufgelöste Darstellung histologischer Auffälligkeiten innerhalb der HL-Tumoren zu sehen. In beiden unter $\mathbf{A}$ und $\mathbf{B}$ gezeigten Aufnahmen sind größere Gefäße zu erkennen, an die angrenzend sich große Einblutungen, mit Pfeilen markiert, gebildet haben. Unter $\mathbf{C}$ und $\mathbf{D}$ sind ebenfalls Gefäße dargestellt, umgeben von Tumorzellen. Die mit Pfeilen markierten HL-Zellen wölben sich in das Lumen vor, dies könnte der Beginn einer Gefäßinvasion sein. Die markierten Zellen sind in dieser Weise auf mehreren angrenzenden Schnitten zu erkennen, sodass hier ein Anschnitteffekt ausgeschlossen werden kann.

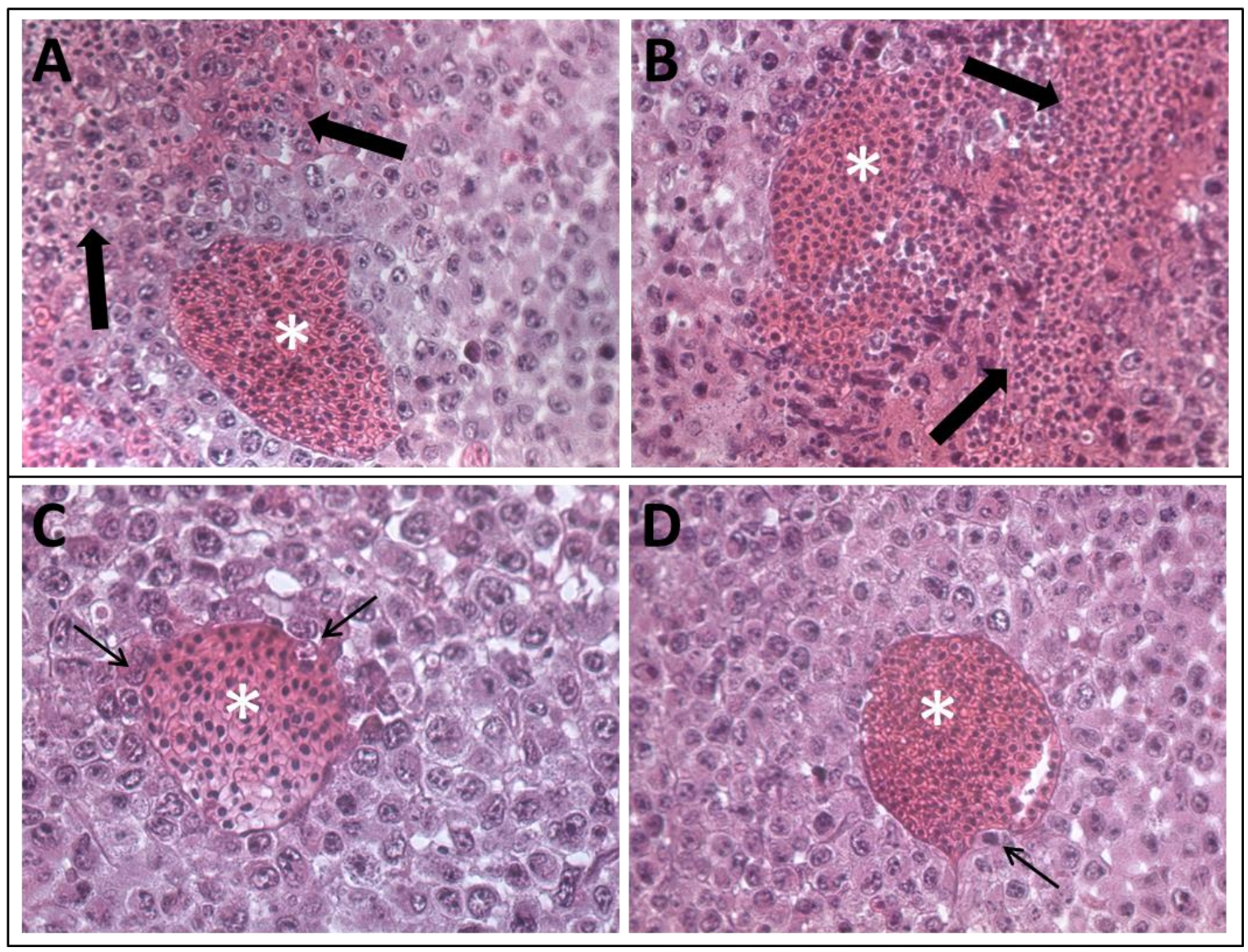

Abbildung 7: In Lymphomen auf der CAM sind Hinweise für eine beginnende Gefäßinvasion erkennbar. A und B. Es sind Aufnahmen zweier Gefäße zu sehen (markiert mit *) mit angrenzendem großflächigem Austritt von Erythrozyten. Die eingebluteten Areale sind mit Pfeilen markiert. C und D. Gezeigt sind exemplarische Aufnahmen von Tumorzellen (Pfeile), die sich an Gefäße $\left(^{*}\right)$ anlagern und die Gefäßwand vorwölben. Dies könnte den Beginn einer Gefäßinvasion darstellen. Alle Aufnahmen wurden mit 400 -facher Vergrößerung erstellt. Es sind beispielhafte Tumoren der Zelllinien L-428 A parental (A,B) und ns-Kontrolle $(\mathrm{C}, \mathrm{D})$ dargestellt.

In Abbildung 8 sind Aufnahmen von Semidünnschnitten dargestellt. Hierzu wurden mit Karnovsky-Lösung fixierte und in Epoxid-Harz eingebettete Tumoren verwendet. Erneut sind in diesen hochauflösenden Bildern die zahlreichen Erythrozyten zu erkennen, die sich außerhalb der Blutgefäße zwischen den Tumorzellen befinden. 


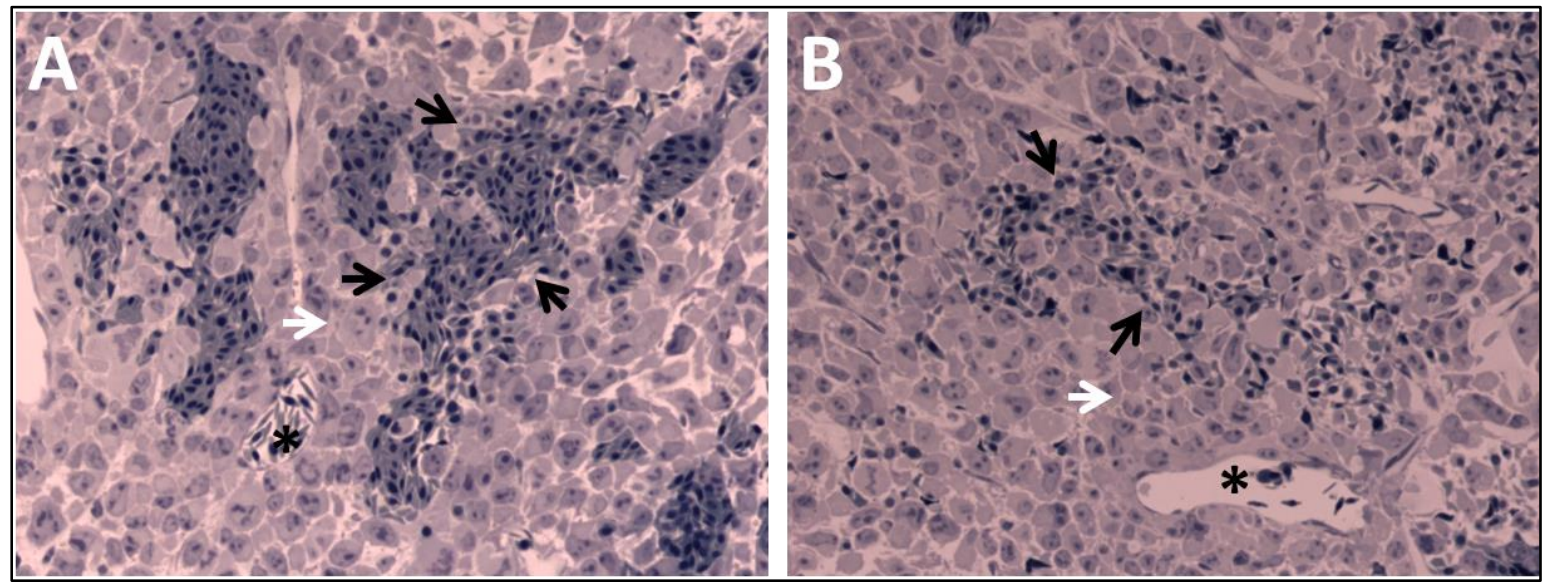

Abbildung 8: Semidünnschnitte von HL-Tumoren zeigen Einblutungen. Die Aufnahmen zeigen ausgetretene Erythrozyten inmitten des Tumorgewebes. Gefäße sind mit $\left(^{*}\right)$ beschriftet, die weiße Pfeile zeigen auf $\mathrm{HL}$-Zellen, die schwarzen auf kernhaltige Hühner-Erythrozyten. Die Aufnahmen wurden mit 400facher Vergrößerung an Karnovsky-fixierten Semidünnschnitten gemacht. Es sind repräsentative Tumoren der Zelllinienchargen L-428 A und L-428 B dargestellt.

Mittels Immunfluoreszenz konnten die Tumoren der GFP-exprimierenden ns-Kontroll-Zellen noch detaillierter histologisch aufgearbeitet werden. Als Antigen zum Nachweis von Blutgefäßen innerhalb des Tumors diente das Protein Mep21, welches auf Endothelzellen von Vogel-Blutgefäßen zu finden ist. Zur Detektion von Lymphgefäßen im Tumor diente der selektiv in Lymphendothelzellen exprimierte Transkriptionsfaktor Prox1. Mit dem rot fluoreszierenden Sekundärantikörper, der blauen DAPI-Färbung sowie der grünen Fluoreszenz der GFP exprimierenden Zellen ergab sich ein insgesamt dreifarbiges Bild.
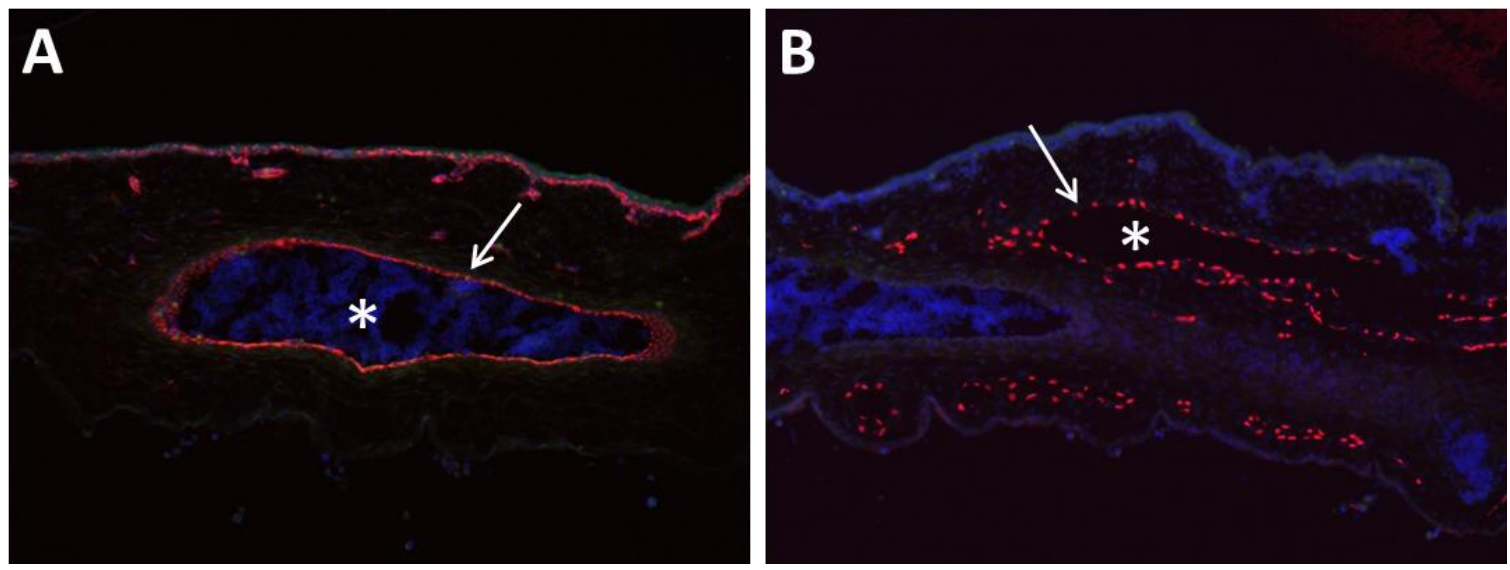

Abbildung 9: Immunfluoreszenz-Aufnahmen zeigen Blut- und Lymphgefäße in physiologischer CAM. A. Mit $\left(^{*}\right)$ ist ein großes Blutgefäß der CAM bezeichnet, gefüllt mit DAPI-positiven Erythrozyten. Der Pfeil zeigt auf die rot gefärbten, Mep21-positiven Blutgefäßendothelzellen. Auf der oberen Seite der CAM kommt ein durchgängiges Netz von Blutkapillaren zur Darstellung. B. In dieser Aufnahme sind die Prox1-positiven Lymphendothelzellen rot dargestellt (Pfeil). Mit $\left({ }^{*}\right)$ ist ein großes Lymphgefäß dargestellt, das sich in direkter Nachbarschaft zu einem großen Blutgefäß, zu erkennen an den vielen Erythrozyten, befindet. Hierbei handelt es sich um das gleiche Blutgefäß wie in A. Beide Aufnahmen wurden von Schnitten einer physiologischen CAM mit einer 50-fachen Vergrößerung aufgenommen. 
In der physiologischen, nicht mit Tumor infiltrierten CAM (Abbildung 9) war die normale Gefäßarchitektur erkennbar. Es fanden sich große Gefäße mit einem durchgehenden Saum von rot gefärbten, Mep21-positiven Blutendothelzellen (Abbildung 9A). Innerhalb der Gefäße waren zahlreiche DAPI-positive Hühnererythrozyten erkennbar. Auf einer Seite der CAM war ein durchgängiges Kapillarbett zu beobachten, dieses war innerhalb des Tumors nicht mehr darstellbar. Die physiologische Architektur der Lymphgefäße ist in Abbildung 9B dargestellt. Prox1-positive Lymphendothelzellen bildeten Lymphgefäße in unmittelbarer Umgebung der größeren Blutgefäße. Die in Abbildung 9 dargestellten Aufnahmen zeigen eine vergleichbare Schnittebene und stellen das gleiche große Blutgefäß dar.
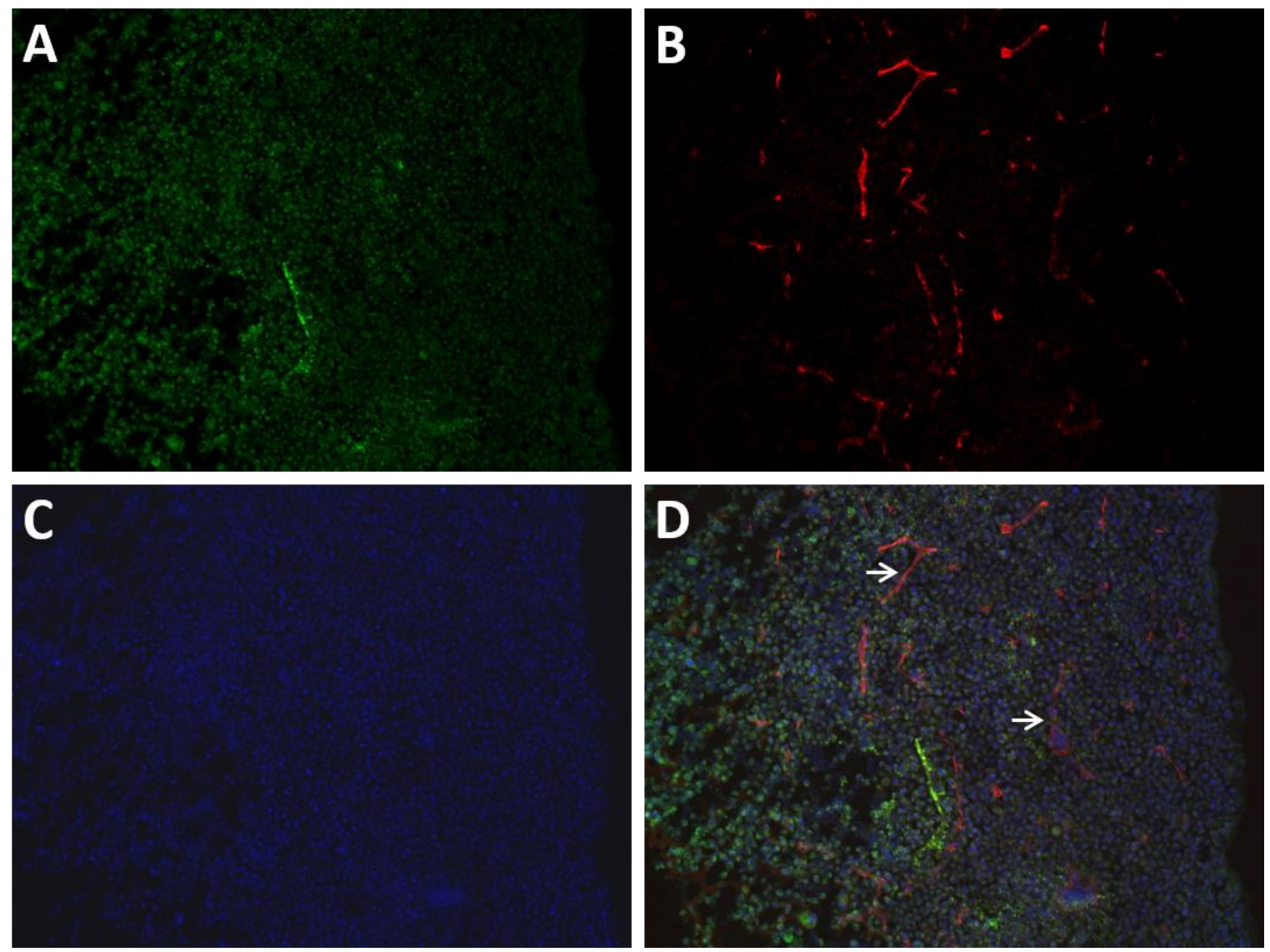

Abbildung 10: HL-Tumoren auf der CAM enthalten irregulär strukturierte Blutgefäße. A. In Grün zeigen sich die dicht gepackten, GFP-positiven Tumorzellen auf der CAM. B. Mit einem roten Fluoreszenz-Antikörper wurden die Mep21-positiven Blutgefäße innerhalb des Tumors dargestellt (Pfeile). Im Tumor sind viele kleine Gefäße zu erkennen, jedoch keine mit einer regulären Struktur. C. Mit dem blau fluoreszierenden Farbstoff DAPI wurden alle kernhaltigen Zellen des Schnittes angefärbt. D. Diese Aufnahme stellt das überlagerte Bild aller drei einzeln dargestellten Kanäle dar, mit Pfeilen sind Blutgefäße innerhalb des Tumors dargestellt. Die Aufnahmen wurden mit 50-facher Vergrößerung von einem Tumor der GFP-positiven Zelllinie L-428 B erstellt.

Abbildung 10 stellt mit Mep21 gefärbte Blutgefäße innerhalb eines charakteristischen HL-Tumors auf der CAM dar. In Abbildung 10B sind die Mep21-positiven Blutgefäße rot gefärbt, einige beispielhafte Gefäße sind mit Pfeilen markiert. Es sind, verglichen mit der physiologischen CAM, deutlich mehr, aber dafür deutlich kleinere und unregelmäßigere 
Blutgefäße zu finden. Die Architektur dieser Tumorblutgefäße unterscheidet sich grundlegend von der der Gefäße in der physiologischen CAM. Es ist kein strukturierter Wandaufbau erkennbar, die Form der Gefäße ist unregelmäßig, sehr schmal und gezackt.

In Bezug auf die Architektur von Lymphgefäßen war der Unterschied zwischen physiologischer CAM und Tumor noch deutlicher ausgeprägt. So konnten innerhalb der HLTumoren so gut wie keine Prox1-positiven Lymphendothelzellen ausgemacht werden (Abbildung 11). Die wenigen erkennbaren Zellen innerhalb des Tumors bildeten keine Gefäße (vgl. Abbildung 9), sondern waren vereinzelt und ohne erkennbares Muster im Tumor verteilt.
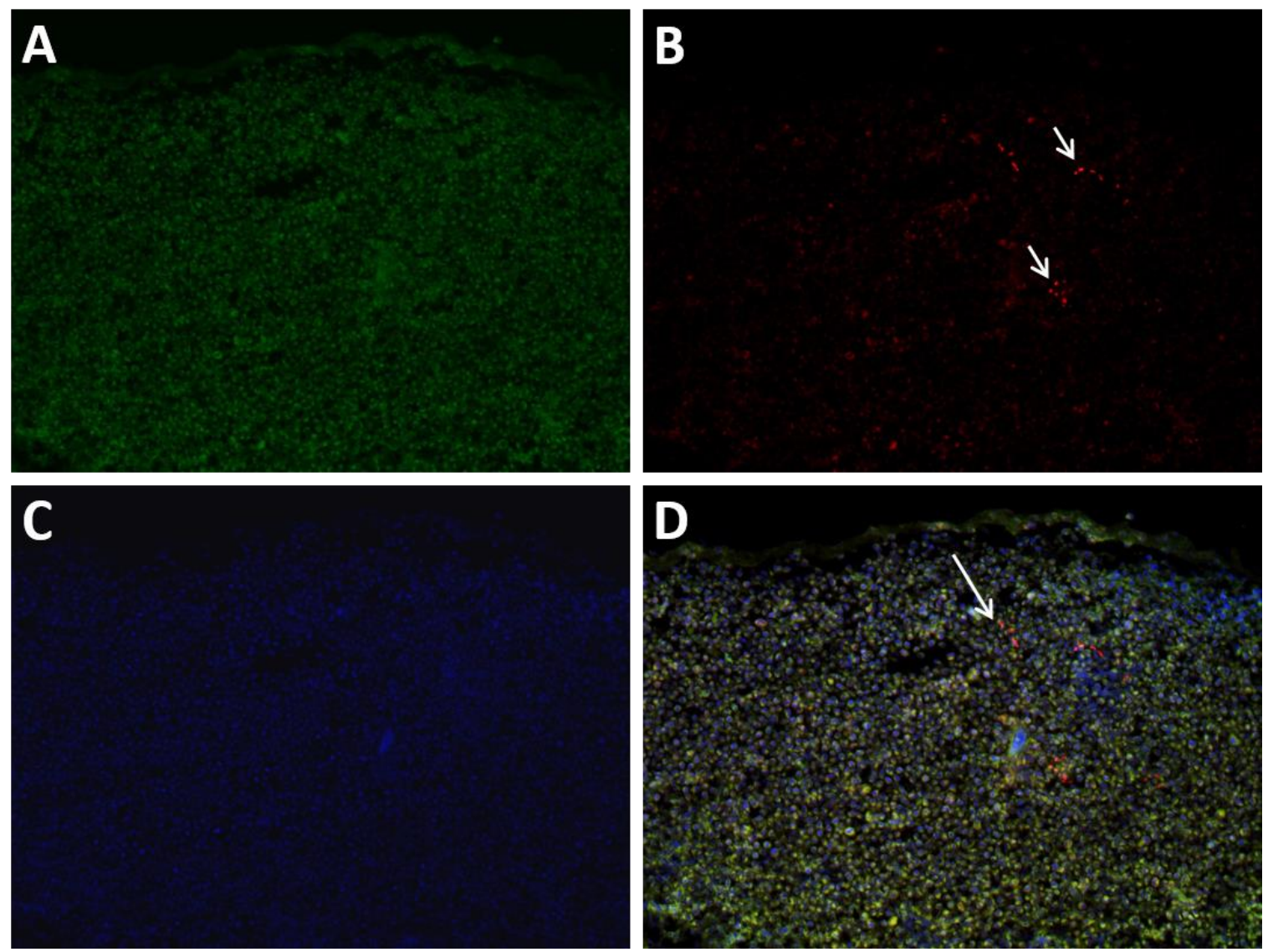

Abbildung 11: In HL-Tumoren auf der CAM sind fast keine Lymphgefäße zu finden. A. In Grün zeigen sich die dicht gepackten, GFP-positiven Tumorzellen auf der CAM. B. Mit einem rot fluoreszierenden Antikörper wurden die Prox1-positiven Lymphendothelzellen innerhalb des Tumors markiert. Im Tumor finden sich nur sehr vereinzelte Lymphendothelzellen (Pfeile), die normale Lymphgefäßarchitektur der CAM ist zerstört. C. Mit dem blau fluoreszierenden Farbstoff DAPI wurden alle kernhaltigen Zellen des Schnittes angefärbt. D. Diese Aufnahme stellt das überlagerte Bild aller drei einzeln dargestellten Kanäle dar, mit dem Pfeil ist eines der wenigen Lymphgefäße innerhalb des Tumors dargestellt. Die Aufnahmen wurden mit 50facher Vergrößerung von einem Tumor der L-428 B (ns-Kontrolle) erstellt.

Um besser nachvollziehen zu können, wie sich die Tumorzellen während der 96-stündigen Inkubationszeit verhalten und wie es zur Bildung von stark hämorrhagischen Tumoren kommt, wurden ex ovo-CAM-Versuche durchgeführt. Die Kultivierung der befruchteten Hühnereier außerhalb der Eierschale ermöglichte das kontinuierliche Beobachten der 
Tumorzellen bereits zu frühen Zeitpunkten, ohne dass der Versuch unterbrochen werden musste.

Zusätzlich zu einer deutlich größeren Schwierigkeit der technischen Umsetzung zeigte sich eine massiv erhöhte Anfälligkeit der Hühnerembryonen. Während bei den in ovo-CAM-Assays 118 von 136 befruchteten Eiern ausgewertet werden konnten (Auswertungsquote 86,8 \%), lag dieser Anteil bei den ex ovo-Versuchen bei 17 von 45 Eiern, entsprechend einer Quote von 37,8 \%. Gründe dafür dürften vor allem ein erhöhter Stress für den Embryo beim Überführen in die Kulturschale sowie eine deutlich erhöhte Anfälligkeit auf äußere Einflüsse wie Temperatur- oder Luftfeuchtigkeitsänderungen sein.
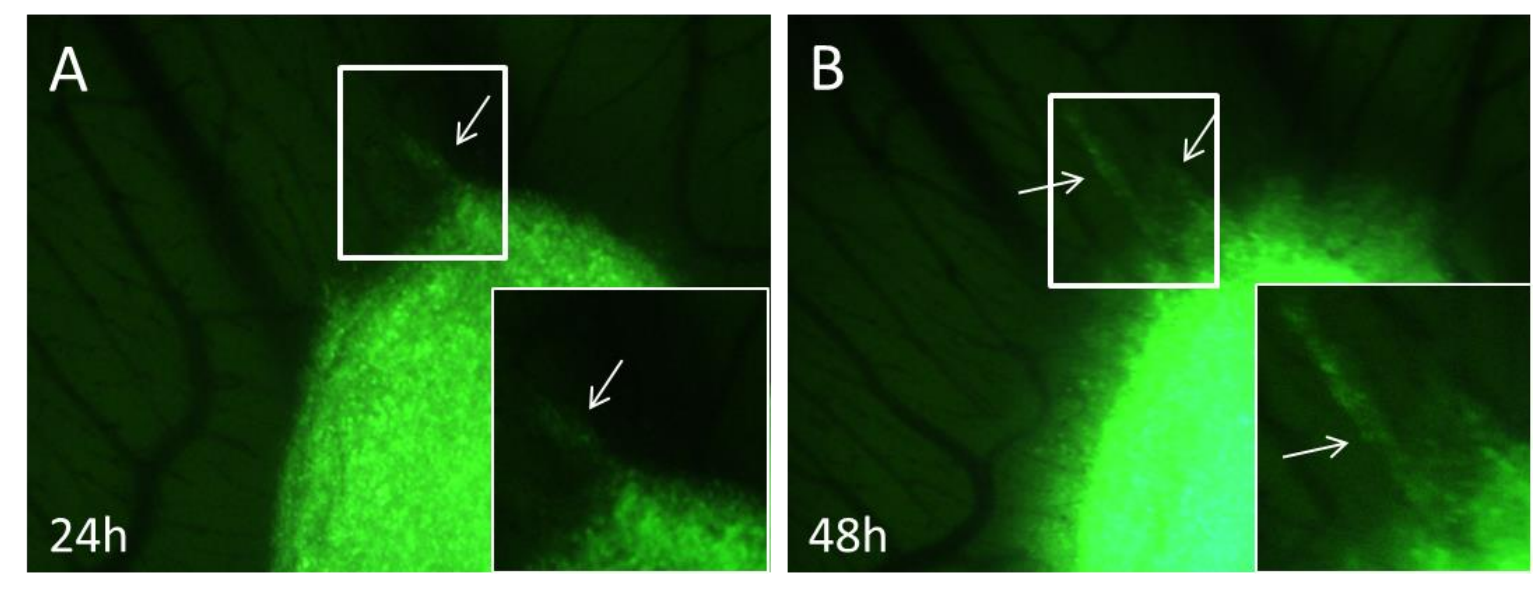

Abbildung 12: Ex ovo-CAM-Assays zeigen, dass HL-Zellen entlang von Gefäßen aus dem Tumor herauswachsen. A. 24 Stunden nach Inkubation im ex ovo-CAM-Modell beginnen GFP-haltige HL-Zellen radiär - entlang von Gefäßen - aus dem Tumor auszuwachsen. B. Nach 48 Stunden ist dieses Phänomen noch ausgeprägter und an mehreren Gefäßen zu beobachten (Pfeile). Die Aufnahmen wurden mit 50-facher Vergrößerung erstellt, im Kasten ist jeweils ein Bildausschnitt separat 100-fach vergrößert.

Unter einem Stereomikroskop konnte die Fluoreszenz der GFP-positiven Tumorzellen sichtbar gemacht werden. Ein besonderer Fokus lag dabei darauf, wie die Tumorzellen aus dem beimpften Tropfen auswachsen und Gefäße anlocken. Zu erkennen war ein radiäres Auswachsens der Tumorzellen entlang von Blutgefäßen, welches bereits nach 24 Stunden gut zu erkennen war und sich im Verlauf weiter steigerte (Abbildung 12). Nach 48 Stunden waren die Zellstränge entlang der Gefäße deutlich prominenter und der gesamte Rand des Tumors wirkte ausgefranst, was für ein Auswachsen der Tumorzellen auf breiter Front spricht.

\subsection{Einfluss von LEF-1 auf das Verhalten von HL-Zellen im Xenograft- Modell}

In diesem dritten Teil der Dissertation wurde der Einfluss des Transkriptionsfaktors LEF-1 auf HL-Zellen im in ovo-Modell untersucht. Dazu wurde wie im vorigen Kapitel die CAM von Hühnereiern verwendet und mit Tumorzellen der HL-Zellinie L-428 beimpft. Die 
entstandenen Tumoren wurden lichtmikroskopisch vermessen und die Größen zwischen den einzelnen Gruppen verglichen.

In Abbildung 13A ist dargestellt, dass sich die CAM-Tumoren der parentalen und nsKontrolle aus Transduktion A in ihrer Größe unterschieden $\left(0,39 \mathrm{~cm}^{2}\right.$ vs $\left.0,31 \mathrm{~cm}^{2}, \mathrm{p}=0,053\right)$, während die LEF-1-defizienten Zellen die kleinsten Tumoren bildeten $\left(0,27 \mathrm{~cm}^{2}, \mathrm{p}=0,37\right)$.

In L-428 B-Zellen (Abbildung 13B) bildeten sich in der parentalen sowie der ns-Kontrollgruppe vergleichbar große Tumoren mit einer durchschnittlichen Größe von $0,41 \mathrm{~cm}^{2}$ beziehungsweise $0,39 \mathrm{~cm}^{2}$. Verglichen dazu waren die entstehenden Tumoren der LEF-1-Knockdown-Gruppe mit $0,25 \mathrm{~cm}^{2}$ hochsignifikant kleiner $(\mathrm{p}=0,007)$.

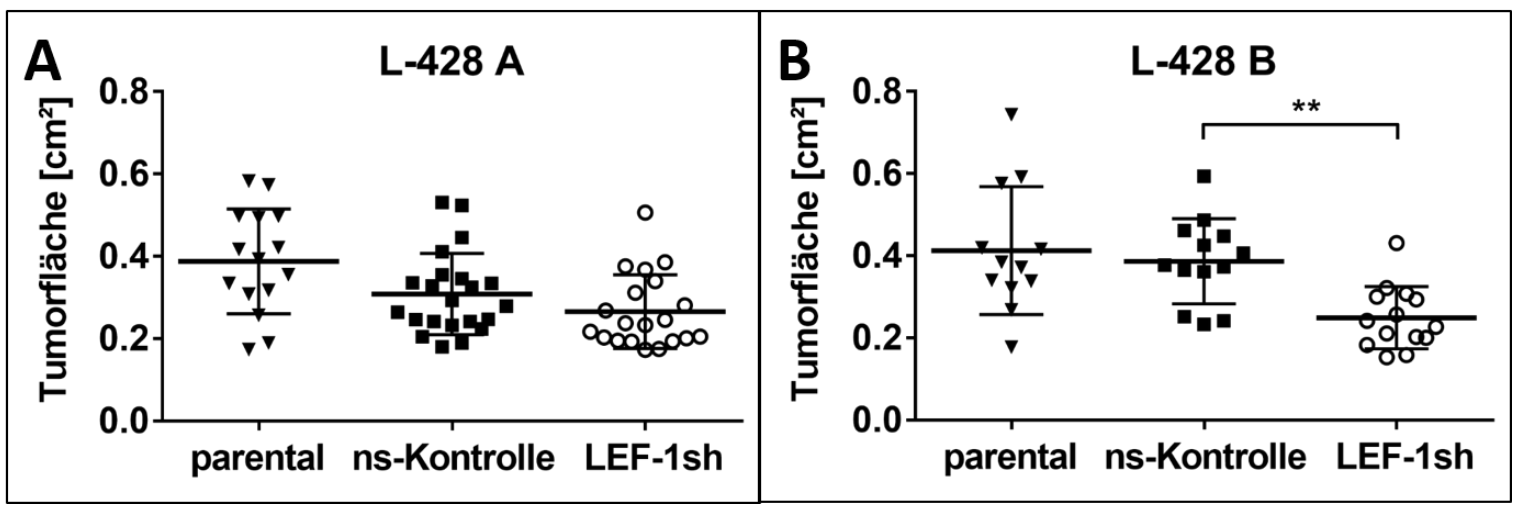

Abbildung 13: Der LEF-1-Knockdown führt zu einer signifikanten Erniedrigung der Tumorgröße im Xenograft-Modell von L-428 B-Zellen. A. In L-428 A-Zellen gibt es keinen signifikanten Unterschied der Tumorgröße zwischen der ns-Kontrolle, der parentalen Kontrolle $(p=0,053)$ sowie der LEF-1-defizienten Zelllinie $(p=0,32)$. B. In L-428 B-Zellen bilden parentale und ns-Gruppe vergleichbar große Tumoren, die Tumoren der LEF-1-Knockdown-Gruppe sind signifikant kleiner $(p=0,007)$. Mittels ImageJ wurde die Fläche der Tumoren im CAM-Assay nach 96 Stunden Inkubationszeit vermessen. (Mittelwert $\pm S D, n=3(A)$ bzw. $\mathrm{n}=2(\mathrm{~B})$, ANOVA mit Bonferroni-Test, $\left.{ }^{* *} \mathrm{p}<0,01\right)$

Mit den lichtmikroskopisch erstellten Fotos der CAM-Tumoren wurde im Anschluss eine Auswertung der Einblutungen mittels eines eigens entwickelten Einblutungs-Scores durchgeführt (Kapitel 2.2.3.4). Hierzu wurden die Fotos verblindet bewertet und mit einer Punktzahl bedacht.

Die Analyse der Score-Ergebnisse ergab keine statistisch signifikanten Unterschiede in der Einblutung zwischen LEF-1-Knockdown und Kontrollen in L-428-Zellen. 
Tabelle 9: Übersicht über die Mittelwerte im Einblutungs-Score. Es waren keine statistisch signifkanten Unterschiede der Punktwerte im Einblutungs-Score zu erheben. Die Mittelwerte der einzelnen Gruppen wurden mittels ANOVA mit Kruskal-Wallis-Test miteinander verglichen, der $p$-Wert ist in Bezug zur jeweiligen ns-Kontrolle angegeben.

\begin{tabular}{|c|l|l|l|}
\hline Zellliniencharge & & \multicolumn{1}{|c|}{ mittlerer Score } & \multicolumn{1}{c|}{ p-Wert } \\
\hline \multirow{3}{*}{ L-428 A } & ns-Kontrolle & 5,93 & \\
\cline { 2 - 4 } & parentale Kontrolle & 6,86 & 0,13 \\
\cline { 2 - 4 } & LEF-1sh & 6,6 & 0,99 \\
\hline \multirow{2}{*}{ L-428 B } & ns-Kontrolle & 5,54 & 0,65 \\
\cline { 2 - 4 } & parentale Kontrolle & 6,55 & 0,82 \\
\cline { 2 - 4 } & LEF-1sh & 4,62 & \\
\hline
\end{tabular}

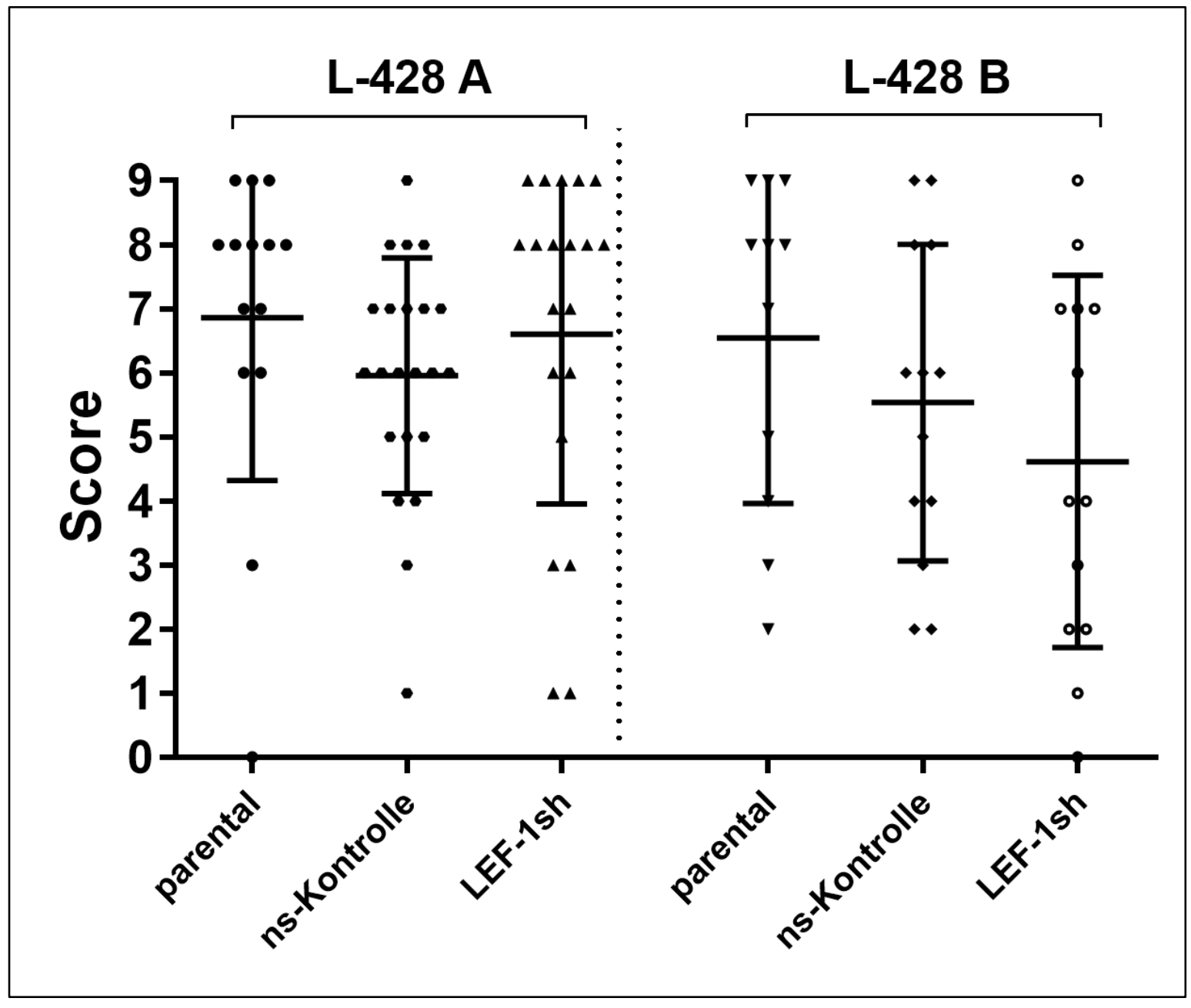

Abbildung 14: Ein LEF-1-Knockdown hat keinen Einfluss auf die Einblutungen von HL-Tumoren im CAM-Assay. Die Lichtbilder der geernteten Tumoren wurden verblindet mit dem Einblutungsscore beurteilt. Es gibt in L-428-Zellen keinen signifikanten Unterschied im Punktwert zwischen der ns-Kontrolle und den LEF-1-defizienten Zellen ( $A, p=0,99 ; B, p=0,82$ ). (Mittelwert $\pm S D, n=3(A)$ bzw. $n=2(B)$, ANOVA mit Kruskal-Wallis-Test) 
In L-428 A-Zellen betrug der durchschnittliche Punktwert in der parentalen Kontrolle 6,9, in der ns-Kontrolle 6,0 und in der LEF-1-Knockdown-Gruppe 6,6 von 9 Punkten, keiner dieser Unterschiede war signifikant. In der Auswertung von L-428 B-Zellen ergab sich ein ähnliches Bild, die durchschnittlichen Punktwerte lagen bei 6,5 (parentale Kontrolle), 5,5 (ns-Kontrolle) beziehungsweise 4,6 (LEF-1-Knockdown). Der Unterschied zwischen ns-Kontrolle und LEF-1-Kontrolle war nicht signifikant, der p-Wert betrug 0,82 .

\subsection{Funktion von LEF-1 für die Interaktion mit Endothelzellen}

In den histologischen Analysen der im CAM-Modell entstandenen HL-Tumoren waren deutliche morphologische Auffälligkeiten der Gefäße innerhalb der Tumoren erhoben worden. Daher wurde in diesem vierten Teil der Dissertation die Interaktion von HodgkinLymphom-Zellen mit Endothelien in vitro geprüft. Dazu wurden Migrationsanalysen von Endothelzellen durchgeführt, weiterhin wurde VEGF-A als möglicher Vermittler von LEF-1Effekten mittels qRT-PCR und ELISA untersucht.

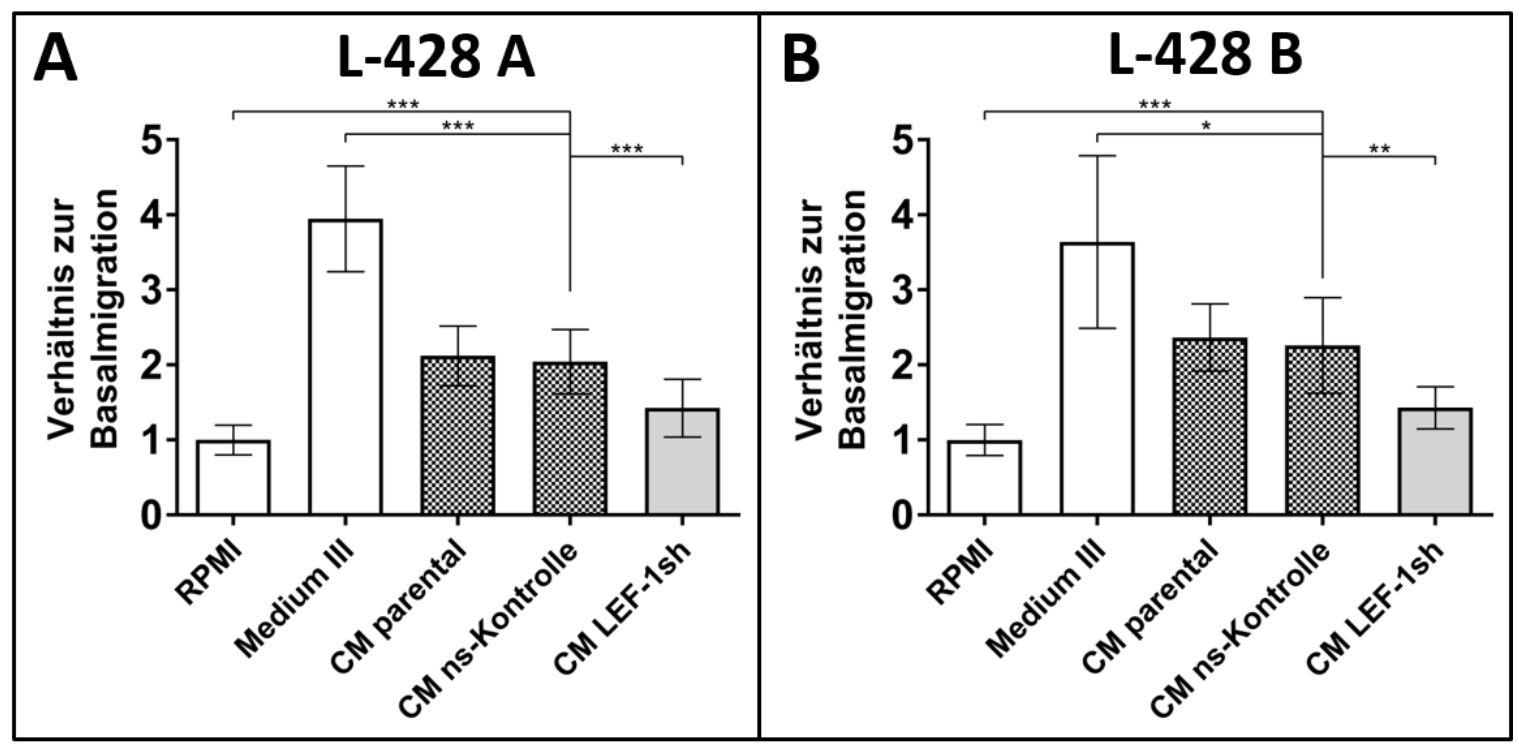

Abbildung 15: LEF-1 beeinflusst die Fähigkeit von HL-Zellen, HUVECs zu invasiver Migration anzuregen. Die Migrationsfähigkeit von HUVECs wurde in Versuchen mit der modifizierten Boyden-Kammer untersucht. HUVECs wurden durch die konditionierten Medien der HL-Zelllinienchargen L-428 A (A) und L-428 B (B) zur invasiven Migration durch eine mit Kolllagen Typ I beschichtete, poröse Membran angeregt. Als Positivkontrolle diente Medium III, als Negativkontrolle RPMI ohne Zusätze. Dargestellt ist das Verhältnis der migrierten Zellen zur Migration der Negativkontrolle. Die Steigerung der Migration durch jedes einzelne CM war im Vergleich zur Negativkontrolle signifikant, dies wurde aus Gründen der Übersichtlichkeit nicht gekennzeichnet. (Mittelwert $\pm \mathrm{SD}, \mathrm{n}=2$, ANOVA mit Bonferroni-Test $(\mathrm{A})$ bzw. Kruskal-Wallis-Test $(\mathrm{B})$ * $\left.\mathrm{p}<0,05 ;{ }^{* *} \mathrm{p}<0.01 ;{ }^{* * *} \mathrm{p}<0,001\right)$

Der Versuchsaufbau der modifizierten Boyden-Kammer diente als erster Ansatz zur Migrationsanalyse. Endothelzellen mussten dabei auf den Reiz eines Chemokins eine mit $8 \mu \mathrm{m}$ großen Poren durchsetzte und mit Kollagen Typ I beschichtete Membran invasiv 
durchwandern. Im Anschluss daran konnte die Zahl der durchwanderten Endothelzellen bestimmt werden und so die Fähigkeit eines Chemokins zur Migrationsstimulation quantifiziert werden. Als Chemokin dienten in diesem Versuchsaufbau die konditionierten Medien (CM) der Tumorzellen (Abbildung 15). Die Zahl der migrierten Zellen wurde in Bezug zur Zahl der migrierten Zellen in Richtung der Negativkontrolle, sprich der Basalmigration, gesetzt.

Die CM der HL-Zellen waren durchweg in der Lage, Endothelzellen zur Migration zu stimulieren. Die Steigerung der Migration war für jedes CM in Bezug zur Basalmigration signifikant. Es kam bei Stimulation mit den CM der LEF-1-exprimierenden Kontrollen zu einer 2-fachen (L-428 A) beziehungsweise 2,4-fachen (L-428 B) Steigerung der Migrationsrate im Bezug zur chemokinfreien Basalmigration. Dabei gab es keinen Unterschied in der Migrationssteigerung zwischen dem CM der parentalen oder der ns-Kontroll-Zelllinie (L-428 A p>0,99, L-428 B p>0,99). Die beiden Kontroll-CM führten jeweils zu einer ungefähr halb so starken Migration von Endothelzellen wie die Positivkontrolle, in dem alle für Endothelzellen relevanten Wachstumsfaktoren enthalten waren.

Die CM der LEF-1-defizienten Zellen hingegen waren deutlich schlechter in der Lage, Endothelzellen zur Migration zu stimulieren. Zwar stimulierten die CM der LEF-1-defizienten Zellen die Endothelzellen zu einer stärkeren Migration als die Negativkontrolle, jedoch lag die Anzahl der migrierten Zellen im Mittel nur bei $69 \%$ (L-428 A) respektive $63 \%$ (L-428 B), bezogen auf die jeweilige ns-Kontrolle. Dieser Unterschied in der Migrationsstimulation zwischen ns-Kontroll-Zellen und LEF-1-Knockdown-Zellen war in beiden Fällen signifikant (L-428 A p <0,001; L-428 B p <0,01).

Um den Einfluss der LEF-1-abhängigen Endothelzellstimulation weitergehend zu quantifizieren, wurden Untersuchungen mittels Scratch-Assay durchgeführt. Bei diesem Versuchsaufbau zur Migrationsanalyse ist das konditionierte Medium in direktem Kontakt mit den Endothelzellen und dient nicht - wie in den Versuchen mit der Boyden-Kammer - als Chemokin. Abbildung 16 A und $\mathbf{B}$ zeigen repräsentative Ergebnisse der Migration bei Stimulation mit der Positivkontrolle (Medium III) beziehungsweise der Negativkontrolle (RPMI). Stimuliert durch Medium III waren die Endothelzellen immer in der Lage, während der Versuchszeit die Wunde komplett zu verschließen, während Stimulation mit RPMI, einem Medium ohne jegliche Zusätze, nur zu einem minimalen Verschluss des Spaltes von durchschnittlich 7,3 Prozent führte. 

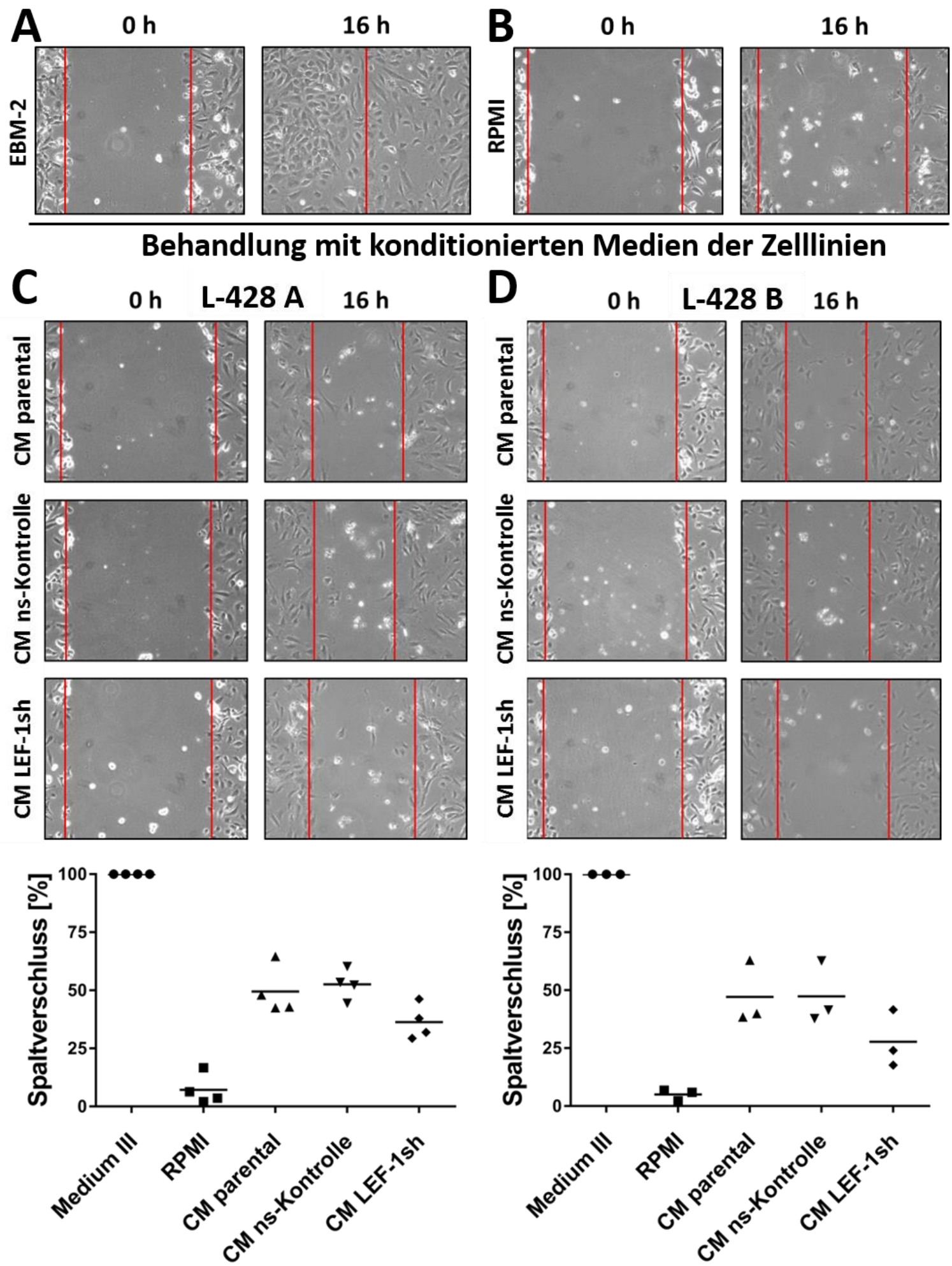

Abbildung 16: LEF-1 beeinflusst die Fähigkeit von HL-Zellen, HUVECs zur Wundheilung zu stimulieren. HUVECs wurden 16 Stunden mit den konditionierten Medien der Tumorzellen inkubiert und die danach gemessene Breite der Wunde auf die jeweilige Anfangsbreite bezogen. Als Positivkontrolle wurde Medium III (A) verwendet, als Negativkontrolle RPMI ohne Zusätze (B). C und D zeigen repräsentative Aufnahmen der gesetzten Wunden nach 0 und 16 Stunden. (Mittelwert, $n=4(C)$ bzw. $n=3(D)$.

Ein repräsentativer Versuch mit den konditionierten Medien von L-428 A-Zellen ist in Abbildung 16C abgebildet. Nach 16 Stunden war die Wunde zu circa 50 Prozent geschlossen, 
wenn die Endothelzellen mit den Medien der LEF-1-exprimierenden parentalen und nsKontroll-Zellen überdeckt waren. Der Unterschied im Spaltschluss zwischen den beiden Kontrollbehandlungen ist in allen vier biologischen Replikaten des Versuchs minimal. Die Behandlung mit dem Medium der LEF-1-defizienten Tumorzellen führte zu einem deutlich verminderten Wundverschluss durch die Endothelzellen, es waren nach 16 Stunden immer noch in etwa zwei Drittel nicht verschlossen.

Im Durchschnitt von vier biologischen Replikaten (Abbildung 16C unten) hat die Behandlung mit Medien der LEF-1-exprimierenden Kontrollgruppen (parentale und nsKontrolle) zum Verschluss von 50 Prozent der Wunde geführt, während das konditionierte Medium der LEF-1-Knockdown-Gruppe nur zu einem etwa 30-prozentigen Verschluss führte.

Abbildung 16D zeigt die entsprechenden repräsentativen Versuchsergebnisse der L-428 BZellen, die Befunde waren hier sehr gut vergleichbar mit denen der L-428 A-Zellen. Auch hier führten die Medien der Kontrollzellgruppen zu einem deutlichen Verschluss der gesetzten Wunde, während das konditionierte Medium der LEF-1-defizienten Zellen weniger Endothelzell-Migration stimulierte. Die Ausmessung der Wunden zeigte bei Stimulierung mit den Medien der Kontroll-Zellen der L-428 B einen etwa 50-prozentigen Wundverschluss. Das Medium der LEF-1-Knockdown-Zellen sorgte hingegen nur für einen 35-prozentigen Verschluss.

Die Ergebnisse der Migrationsanalysen bestätigen die Hypothese, dass HL-Zellen in der Lage sind, Endothelzellen zur Migration zu stimulieren. Diese Fähigkeit zur Endothelzellstimulation ist LEF-1-abhängig. Daher kann davon ausgegangen werden, dass HL-Zellen LEF-1-abhängig Faktoren in ihre Umgebung sezernieren, die für die Migration von Endothelzellen von großer Bedeutung sind.

Um zu untersuchen, welcher von den HL-Zellen sezernierte Faktor für die Stimulation der Endothelzellen verantwortlich ist, wurden qRT-PCR-Untersuchungen der Genexpression von $V E G F A$ durchgeführt, dem wichtigsten pro-angiogenen Wachstumsfaktor (Abbildung 17). Es zeigte sich, dass sich die VEGFA-Expression in L-428-Zellen nicht wesentlich zwischen parentaler Linie, ns-Kontrolle und LEF-1-Knockdown unterschied. Diese Ergebnisse waren konsistent mit zuvor erhobenen Ergebnissen dieser Arbeitsgruppe, die in Zellen mit transientem LEF-1-Knockdown ebenfalls keinen Einfluss von LEF-1 auf die Expression von $V E G F A$ fanden. 


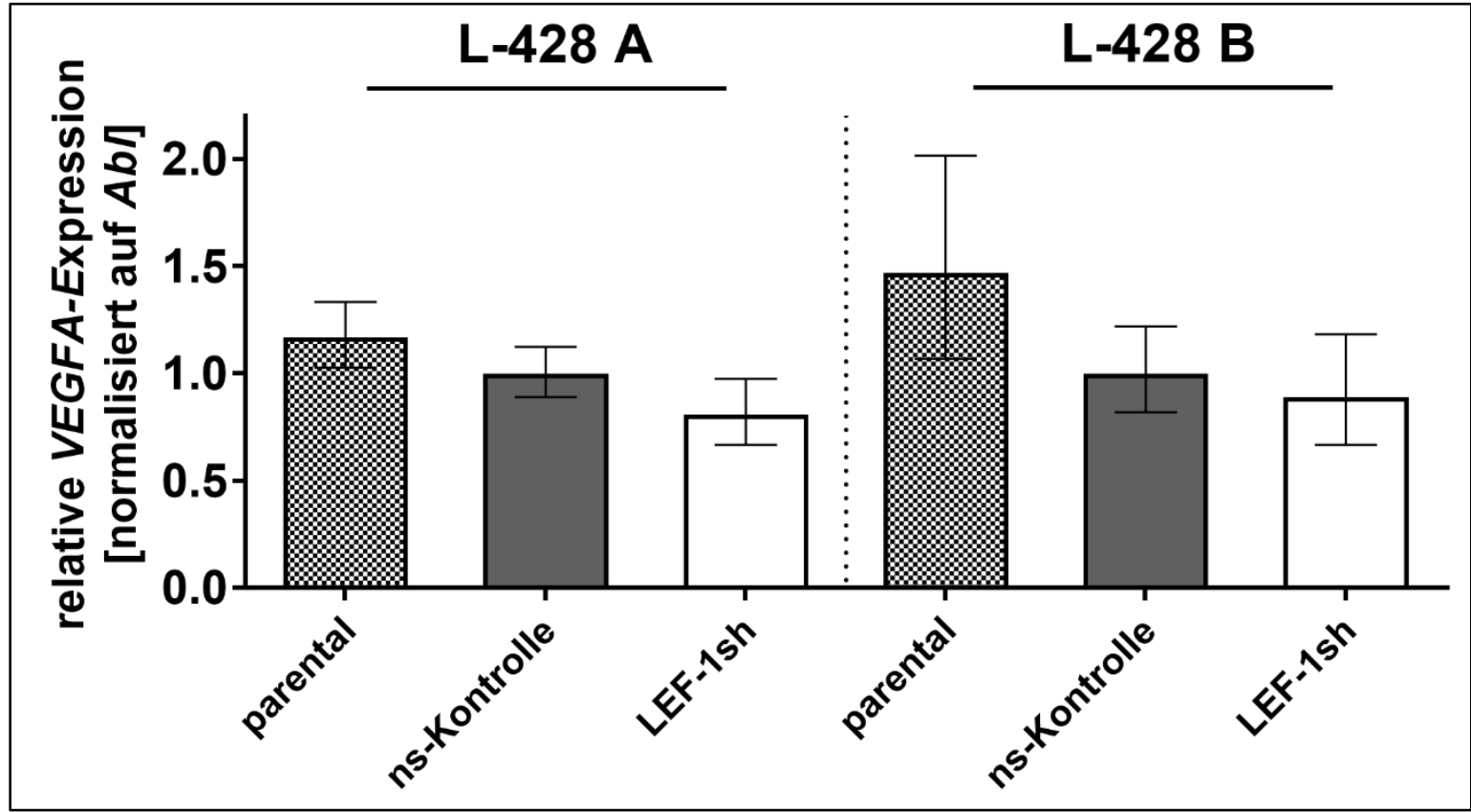

Abbildung 17: Die VEGFA-Expression ist in HL-Zellen mit verminderter LEF-1-Proteinmenge nicht signifikant verändert. Quantitative RT-PCR von Zellysaten der Zelllinienchargen L-428 A (links) und L-428 B (rechts). Angabe der relativen VEGFA-Expression bezogen auf die jeweilige ns-Kontrolle. Alle Werte wurden auf das konstitutiv exprimierte Gen $A B L$ normalisiert. ( $n=1$, Mittelwert \pm oberer/unterer Grenzwert.)

Daran anschließend wurde die Konzentration von VEGF-A im konditionierten Medium der HL-Zelllinien mittels ELISA-Untersuchungen bestimmt. Diese zeigten sowohl in der Zelllinie L-428 A (Abbildung 18A) als auch in der L-428 B (Abbildung 18B) keinen Unterschied in der VEGF-A-Konzentration zwischen der parentalen Zelllinie und der ns-Kontrolle.

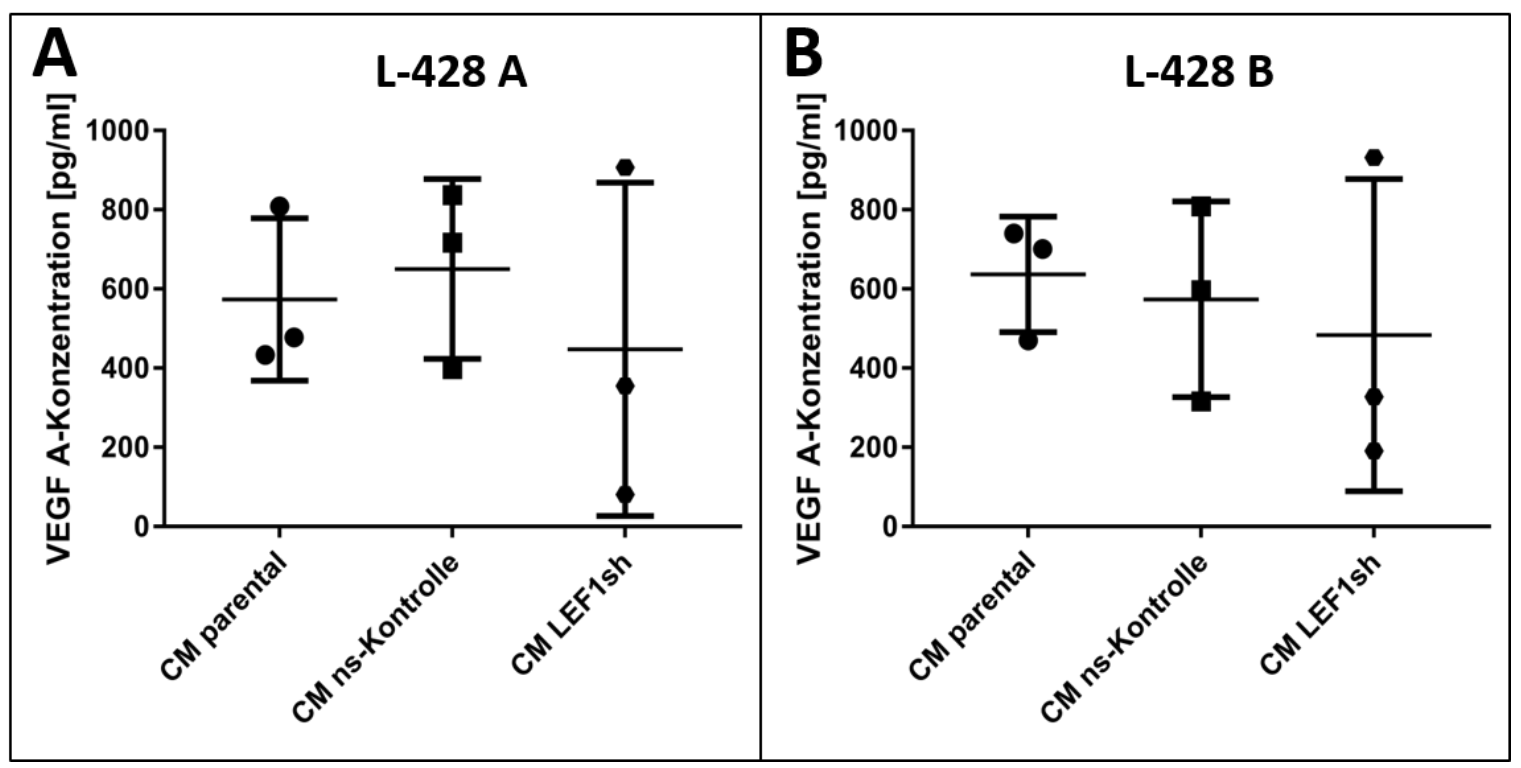

Abbildung 18: Bestimmungen der VEGF-A-Konzentration im konditionierten Medium von HL-Zellen. Die VEGF-A-Konzentration in den konditionierten Medien der HL-Zelllinien wurde mittels ELISA bestimmt. Die VEGF-A-Konzentration im konditionierten Medium nach LEF-1-Knockdown scheint geringer zu sein, weist aber auch eine deutlich höhere Streuung auf. Dieser Versuch wurde freundlicherweise von Dr. Weich am Helmholtz-Institut in Braunschweig mit von mir erstellten Proben durchgeführt. (Mittelwert $\pm S D, n=3$ ) 
So sezernierten die parentale Zelllinie und die ns-Kontrolle der L-428 A im Schnitt etwa 600 pg/ml, der VEGF-A-Gehalt in den Kontrollen der L-428 B lag geringfügig höher. Der VEGF-A-Gehalt im konditionierten Medium der LEF-1-defizienten HL-Zellen war hingegen in beiden Zelllinien etwas geringer und wies eine deutlich höhere Schwankung auf. Es ergab sich ein Mittelwert von $450 \mathrm{pg} / \mathrm{ml}$ für die LEF-1-Knockdown-Zelllinie der L-428 A und von $490 \mathrm{pg} / \mathrm{ml}$ für die der L-428 B. In beiden LEF-1-Knockdown-Zelllinien war bei jeweils zwei Untersuchungen die VEGF-A-Konzentration deutlich geringer als in den Kontrollen, in der jeweils dritten Messung hingegen sogar etwas höher als der Mittelwert der Kontrollen. Dies führte zu einer enorm großen Standardabweichung, sodass sich in diesen Versuchen keine statistische Signifikanz ergab. Insgesamt könnten die Daten auf einen geringeren VEGF-AGehalt im Medium der LEF-1-defizienten HL-Zellen hindeuten, sind aber nicht ausreichend aussagekräftig. 


\section{Diskussion}

Die Zielsetzung dieser Arbeit lag darin, Zelllinien des Hodgkin-Lymphoms im in vivo-Modell der CAM zu charakterisieren und einen eventuellen Einfluss des Transkriptionsfaktor LEF-1 auf deren Verhalten zu untersuchen. Es konnte gezeigt werden, dass die Blutgefäße innerhalb der HL-Tumoren eine irreguläre Architektur aufweisen und dass Lymphgefäße völlig fehlen. Zudem zeigte sich in einer Zellliniencharge ein durch LEF-1-Knockdown verringertes Tumorwachstum.

Eine weitere Fragestellung betraf die Interaktion von HL-Zellen mit Endothelzellen. Hier wurde gezeigt, dass HL-Zellen in der Lage sind, Endothelzellen zur Migration zu stimulieren und dass LEF-1 einen Einfluss auf diese Fähigkeit hat. LEF-1 könnte dabei über eine Regulation der Ausschüttung des proangiogenen Wachstumsfaktors VEGF-A die Migrationsstimulation beeinflussen, eine endgültige Aussage kann aber mit den hier erhobenen Daten nicht getroffen werden.

\subsection{Charakterisierung des in ovo-CAM-Modells von HL-Tumoren}

In dieser Dissertation wurde das Verhalten zweier unabhängiger Chargen der HL-Zelllinie L-428 im CAM-Modell untersucht. Hierbei handelt es sich um eine einfache und reproduzierbare Methode zur Untersuchung der Tumorentstehung und der Angiogenese in ovo (Irvin et al. 2014; Ribatti 2014). Nach der Applikation der Zellen auf die CAM erfolgte binnen 96 Stunden die Formation eines Tumors, der im Durchschnitt für die parentalen Zellen eine Größe von $0,31 \mathrm{~cm}^{2}$ (L-428 A) und $0,39 \mathrm{~cm}^{2}$ (L-428 B) besaß. Diese Durchschnittsfläche ist größer als die der von der Burkitt-Lymphom-Zelllinie BL-2 gebildeten Tumoren, welche eine Größe von im Mittel 0,27 $\mathrm{cm}^{2}$ aufwiesen (Wilming 2017). Dies steht im Gegensatz zu der deutlich höheren Proliferationskapazität der Zelllinien des Burkitt-Lymphoms, die sich auch in der kürzeren Generationszeit von 24 Stunden - im Gegensatz zu den 48 Stunden der HLZelllinien - niederschlägt. Diese Ergebnisse sprechen dafür, dass die Zellen des HodgkinLymphoms auf andere Weise einen Wachstumsvorteil im in ovo-Modell erlangen. Ein Erklärungsansatz wäre die enorm hohe Migrationskapazität der HL-Zellen, die um ein Vielfaches höher liegt als die der BL-Zelllinien, was in Vorarbeiten der Arbeitsgruppe gezeigt werden konnte. Darüber hinaus sind HL-Zellen besonders gut in der Lage, ihre direkte Umgebung zu beeinflussen und zu ihren Gunsten zu gestalten (Liu et al. 2014).

Diese Fähigkeit zur Beeinflussung der Umgebung zeigte sich in dieser Dissertation auch darin, 
dass ein großer Teil der HL-Tumoren große hämorrhagische Zonen aufwies. Mittels eines eigens entwickelten Scores zur Bewertung der Einblutungen konnte dieser Effekt quantifiziert werden. Hiernach wiesen die Tumoren der Zelllinie L-428 in 92,3 (L-428 A) respektive 81 Prozent (L-428 B) relevante Einblutungen auf. Wilming (2017) beschrieb vergleichbare Einblutungen nur bei 17 - 32 Prozent der BL-Tumoren.

Wie Marinaccio et al. (2014) berichteten, lagen bis vor kurzem keine Daten zur Morphologie der Tumorgefäße im Hodgkin-Lymphom vor. Aus diesem Grund wurden in dieser Arbeit die Lymph- und Blutgefäße innerhalb des Tumors mittels Immunfluoreszenz untersucht. Dabei zeigte sich überraschenderweise, dass innerhalb der Tumoren so gut wie keine Lymphgefäße mehr zu finden waren, während diese in der physiologischen CAM abseits des Tumors gut darzustellen waren. In den Tumoren selbst fanden sich allenfalls ganz vereinzelte Prox1-positive Lymphendothelzellen. Dieses Phänomen war konsistent in allen untersuchten Tumoren der Zelllinie L-428 zu beobachten. Eine mögliche Erklärung für diese Befunde wäre, dass HL-Zellen im CAM-Modell die Lymphendothelzellen aktiv zerstören.

Außerdem zeigten sich in den Tumoren auffällige Blutgefäße. So fanden sich innerhalb des Tumors, verglichen mit der physiologischen CAM, deutlich mehr, aber dafür deutlich kleinere Mep21-positive Blutgefäße. Diese waren zudem deutlich irregulär strukturiert und umgeben von großen Ansammlungen von Erythrozyten als histologisches Korrelat der Einblutungen. Einerseits könnte dieser unstrukturierte Wandaufbau der Tumorblutgefäße, als Korrelat der oben beschriebenen Vorgänge an den Lymphgefäßen, durch eine beginnende Zerstörung dieser Gefäße durch die Tumorzellen bedingt sein.

Andererseits könnte es sich bei diesen irregulären Gefäßen auch um neu eingewachsene Blutgefäßen im Rahmen einer durch den Tumor initiierten Angiogenese handeln (Carmeliet und Jain 2011). Tumorblutgefäße werden aufgrund einer ,abnormalen Struktur“ und „chaotischen Organisation“ oft als leaky vessels bezeichnet (Potente et al. 2011, S.881). Diese allgemeine Beschreibung solcher Gefäße deckt sich mit den histologischen Befunden dieser Arbeit. In anderen Lymphom-Entitäten wurden bereits abnorme Tumorgefäße beschrieben (Ribatti et al. 2013). Ribatti et al. (1996) zeigten eine Assoziation von aggressiven B-NHL mit schlecht organisierten Tumorgefäßen, während indolente NHL eher normal strukturierte Gefäße mit einem physiologischen Aufbau der Basalmembran aufwiesen.

Wie Marinaccio et al. (2014) berichteten, liegen bisher nur sehr begrenzte Daten zur Ultrastruktur von Tumorblutgefäßen im Hodgkin-Lymphom vor. Eine griechische Studie untersuchte Material von 286 Patienten mit Hodgkin-Lymphom und korrelierte die Gefäßgröße und -dichte innerhalb des Tumors mit verschiedenen klinischen Parametern (Korkolopoulou et al. 2005). Die Autoren dieser Studie zeigten beispielsweise unter anderem, 
dass flache Tumorgefäße, wie sie auch in dieser Dissertation gefunden wurden, mit einem schlechten failure free survival, also dem Überleben ohne Therapieversagen, assoziiert waren (Korkolopoulou et al. 2005).

Um die erhobenen Befunde zur Gefäßarchitektur genauer zu untersuchen, sind weitere Experimente von Nöten. Insbesondere wäre eine Untersuchung von HL-Tumoren auf der CAM in Form einer Zeitreihe zielführend. Dabei könnte mit histologischen Methoden überprüft werden, wann es zur Zerstörung der Lymphendothelzellen und zur Beeinflussung der Blutgefäßarchitektur kommt. Weiterhin besteht zum jetzigen Zeitpunkt noch Unklarheit darüber, auf welche Weise eine mögliche Zerstörung der Lymphgefäße stattfindet. Hierzu könnte beispielsweise mit einer RNA-Sequenzierung der HL-Zelllinien nach möglichen Genen gesucht werden, die eine solche Destruktion der Gefäßarchitektur vermitteln könnten. Diese könnten dann in einem zweiten Schritt zum Beispiel mittels CRISPR-Methode (Clustered regularly interspaced short palindromic repeats (CRISPR)) ausgeschaltet werden, um die Relevanz dieser Gene für die Destruktionsprozesse zu untersuchen (Jinek et al. 2012; Sánchez-Rivera und Jacks 2015).

Abschließend wurden die HL-Zellen auch in der ex ovo-CAM-Methode untersucht, die eine kontinuierliche Beobachtung des Tumorwachstums ermöglicht. Dabei zeigte sich in den HL-Tumoren bereits nach 24 Stunden ein radiäres Auswachsen der GFP-positiven Tumorzellen entlang von Gefäßen, nach 48 Stunden war dieses Phänomen noch deutlich stärker ausgeprägt. Dies deckt sich mit vergleichbaren Untersuchungen zum BurkittLymphom, allerdings trat hier das Auswachsen aus dem Tumor erst nach 72 bis 96 Stunden, also deutlich später, auf (Klingenberg et al. 2014; Ueberdiek 2016). Ein ähnlicher Effekt mit einem Auswachsen von auf die CAM applizierten Tumorzellen entlang von Gefäßen wurde beispielsweise für eine hoch disseminierende Fibrosarkom-Zelllinie beschrieben (Deryugina und Quigley 2008). Es konnten zu keinem Zeitpunkt der Versuche HL-Zellen innerhalb der Blutgefäße der Hühner-Embryonen beobachtet werden, sodass die Dissemination entlang von Gefäßen eine Möglichkeit der Ausbreitung der Tumorzellen darstellen könnte. Tiefergehende histologische Analysen zu verschiedenen Zeitpunkten der Tumorentwicklung würden ermöglichen, genauere Aussagen über die zu Grunde liegenden Disseminationsprozesse der HL-Zellen zu treffen.

\subsection{Einfluss von LEF-1 auf das Verhalten im CAM-Modell}

Deregulierte Signalwege sind in malignen Erkrankungen allgemein und speziell im HodgkinLymphom eine essenzielle Voraussetzung für die Entstehung und das Voranschreiten der 
Erkrankung (Hanahan und Weinberg 2011; Küppers et al. 2012). Der Wnt-Signalweg ist einer der Signalwege, die am häufigsten in malingnen Erkrankungen dereguliert sind (Polakis 2012). Darauf aufbauend wurde in dieser Dissertation die Relevanz des kanonischen WntSignalweges mit dem Transkriptionsfaktor LEF-1 im Hodgkin-Lymphom untersucht.

Es konnte gezeigt werden, dass in L-428 B-Zellen ein Knockdown von LEF-1 zu einer signifikant geringeren Tumorgröße führt. LEF-1 ist in vielen malignen Entitäten als relevanter Faktor der Tumorprogression beschrieben worden. Beispielsweise konnten Wang et al. (2013) das Tumorwachstum von Kolonkarzinom-Zelllinien im Xenograft-Modell mit einem LEF-1Knockdown signifikant reduzieren.

In L-428 A-Zellen hingegen war der Effekt des LEF-1-Knockdowns auf die Tumorgröße nicht zu beobachten, die Tumoren der LEF-1-defizienten Zellen waren zwar im Schnitt kleiner als die der ns-Kontrolle, allerdings war dieser Unterschied nicht signifikant. Weiterhin waren die Tumoren der ns-Kontrolle durchschnittlich kleiner als die der parentalen Zellen auch hier nicht signifikant - sodass sich insgesamt ein stufenförmiges Bild ergab. Diese Ergebnisse decken sich in gewisser Weise mit den Daten der Western Blot- und qRT-PCRUntersuchungen: In diesen Versuchen waren in L-428 A-Zellen Unterschiede in der Genexpression und des Proteingehalts zwischen der parentalen Kontrolle und der transduzierten ns-Kontrolle zu vermuten. Es ist auf Basis dieser Daten nicht auszuschließen, dass die erste lentivirale Transduktion (L-428 A) gewisse off-target-Effekte in der ns-Kontrolle zur Folge hatte, die zu einer geringeren Expression von LEF-1 führten.

Ähnliches wurde beispielsweise von Song et al. (2015) und Baek et al. (2014) berichtet, in deren Arbeiten zielgerichtete shRNA unerwünschte Nebeneffekte in den jeweils transduzierten Zellen aufwiesen. Nichtsdestotrotz stellte der stabile LEF-1-Knockdown eine notwendige Voraussetzung für die über mehrere Wochen andauernden in vivo-Versuche dar, da es beispielweise bei transienten Knockdowns schneller zu einem Verlust der unterdrückenden Wirkung der interferierenden RNA kommt. Valide Aussagen über die Effekte von LEF-1 in vivo wären daher nicht sicher möglich gewesen. In Zukunft wäre beispielsweise die CRISPRMethode, bei der bestimmte DNA-Abschnitte gezielt ausgeschnitten werden können, eine Möglichkeit, die unerwünschten Nebeneffekte einer lentiviralen Transduktion zu umgehen (Jinek et al. 2012; Sánchez-Rivera und Jacks 2015).

\subsection{Interaktion von HL-Zellen mit Endothelzellen}

Die erhobenen Auffälligkeiten der Gefäßstruktur in den HL-Tumoren in ovo führten zu der Fragestellung, inwieweit HL-Zellen mit Endothelzellen interagieren und ob diese Interaktion 
LEF-1-abhängig sei. In den hierzu durchgeführten HUVEC-Migrationsanalysen zeigte sich, dass HL-Zellen in der Lage sind, HUVECs zur Migration zu stimulieren und dass diese Fähigkeit zu einem großen Teil LEF-1-abhängig ist. Dieser Effekt war mit den konditionierten Medien von beiden untersuchten HL-Zellinienchargen und in beiden Migrationsassays konsistent zu beobachten.

Diese Daten verdeutlichen eine enge Interaktion zwischen HL-Zellen und Endothelzellen, über die bislang nur sehr wenige Daten vorlagen (Steidl et al. 2011; Marinaccio et al. 2014). Celegato et al. (2015) präsentierten erstmals Daten zur Interaktion zwischen Endothelzellen und HL-Zellen. Sie konnten zeigen, dass das konditionierte Medium der HL-Zelllinie L-540 HUVECs zur Migration und Tubulogenese anregen konnte. Die Ergebnisse dieser Dissertation erweitern diese Daten insofern, als dass die von Celegato et al. (2015) verwendete Zelllinie L-540 T-Zell-Ursprungs ist, während die in dieser Arbeit verwendete HL-Zelllinie L-428 vom deutlich häufigeren B-Zell-Ursprung ist (Falk et al. 1987).

Um zu analysieren, auf welche Weise LEF-1 die Fähigkeit der HL-Zellen, Endothelzellen zur Migration zu stimulieren, beeinflusst, wurde der Wachstumsfaktor VEGF-A untersucht. VEGF-A ist der potenteste Induktor der Angiogenese (Matsumoto und Ema 2014) und wird in so gut wie allen soliden Tumoren exprimiert (Ferrara und Davis-Smyth 1997).

Untersuchungen in dieser Dissertation mittels qRT-PCR ergaben eine Expression von $V E G F A$ in beiden untersuchten HL-Zelllinien, konsistent mit publizierten Voruntersuchungen (Doussis-Anagnostopoulou et al. 2002). Diese Expression war nicht LEF-1-abhängig, was in weiteren transienten LEF-1-Knockdown-Zelllinien bestätigt werden konnte. Auf Basis dieser Ergebnisse kann daher nicht von einem Effekt von LEF-1 auf die Transkription von VEGFA in den untersuchten HL-Zelllinien ausgegangen werden kann.

Die durchgeführten ELISA-Messungen lassen keinen sicheren Schluss zu, ob im konditionierten Medium der LEF-1-Knockdown-Zelllinien ein verringerter Gehalt von VEGF-A vorliegt. Die hier erhobenen Daten weisen für beide Zelllinienchargen (L-428 A und L-428 B) in der jeweils dritten Messung eine große Abweichung von den anderen beiden Messungen auf, was zu einer großen Standardabweichung führt. Dies könnte beispielsweise an biologischen Schwankungen des VEGF-A-Gehaltes, der sich im Bereich von einigen Hundert Pikogramm bewegt, liegen und müsste durch weitere ELISA-Messungen bestätigt werden. In der Arbeitsgruppe wurden Daten eines transienten LEF-1- und $\beta$-Catenin-Knockdowns erhoben, bei denen ein Effekt auf den VEGF-A-Gehalt des konditionierten Mediums deutlicher zu erkennen ist.

Von Ekström et al. (2014) wurden interessante Daten bezüglich eines möglichen Einflusses auf die VEGF-A-Sekretion vorgelegt: Sie fanden in Melanom-Zelllinien, die mit dem Wnt- 
Liganden WNT5A behandelt wurden, ebenso keine Steigerung der VEGFA-Expression, aber stattdessen eine Steigerung der Sekretion von VEGF-A in das umgebende Medium (Ekström et al. 2014). Der genaue Mechanismus der Regulation von VEGFA durch LEF-1 bleibt allerdings zum jetzigen Zeitpunkt ungeklärt und müsste in zukünftigen Versuchen weiter untersucht werden.

Nachdem VEGF-A lange Zeit vor allem mit soliden Tumoren assoziiert wurde, hat sich in letzter Zeit jedoch auch eine Relevanz für verschiedene hämatologische Malignitäten herauskristallisiert. So ist eine erhöhter Blutserumspiegel von VEGF-A im follikulären Lymphom mit einem signifikant schlechteren progressionsfreien Überleben korreliert (Labidi et al. 2010), Yang et al. (2015) beschrieben eine Überexpression von VEGFA als schlechten Prognosemarker für Non-Hodgkin-Lymphome im Allgemeinen. Auch im Hodgkin-Lymphom wird VEGFA exprimiert, und eine Nachbeurteilung von Steidl et al. (2010) veröffentlichten HL-Patientendaten ergab eine Korrelation einer VEGFA-Expression mit einem signifikant schlechteren Gesamtüberleben (Linke 2016). Interessanterweise wurde bereits vor einigen Jahren eine Phase-2-Studie mit einer Kombinationstherapie des VEGF-A-Antikörpers Bevacizumab und der Polychemotherapie ABVD (Akronym für die verwendeten Chemotherapeutika Adriamycin, Bleomycin, Vinblastin und Dacarbazin) eingeleitet. Diese ist auf der Website www.clinicaltrials.gov registriert (Identifikationsnummer NCT00722865) und wurde vor kurzem beendet, die Ergebnisse waren bei Abschluss dieser Arbeit allerdings noch nicht publiziert (Abramson 2017). In jedem Fall könnte mit dieser Studie lediglich die Wirksamkeit und Sicherheit dieser Medikamentenkombination im Hodgkin-Lymphom gezeigt werden, eine eventuelle Überlegenheit im Vergleich zur momentanen Standardtherapie könnte erst mit einer anschließenden Phase-3-Studie nachgewiesen werden.

Diese Ergebnisse zur Relevanz des kanonischen Wnt-Signalweges und des Transkriptionsfaktors LEF-1 in Bezug auf die Tumorentwicklung und die Angiogenese im Hodgkin-Lymphom passen zur Assoziation von LEF-1 mit hämatologischen Erkrankungen. In der akut lymphoblastischen Leukämie (ALL) wurde LEF-1 als verändert exprimiert beschrieben (Mullighan et al. 2007) und Kühnl et al. (2011) assoziierten eine LEF-1Überexpression mit einer schlechten Prognose in der ALL. Darüber hinaus ist LEF-1 in NonHodgkin-Lymphomen, wie der chronisch lymphatischen Leukämie oder dem MantelzellLymphom, als überexprimiert bekannt (Gelebart et al. 2008; Gutierrez et al. 2010). Walther et al. (2013) konnten in 16 von 18 Patientenproben des Burkitt-Lymphoms eine aberrante LEF-1-Expression nachweisen und dessen transkriptionelle Aktivität in dieser LymphomEntität aufzeigen. 
Auf Grundlage dieser Publikationen kann die Rolle von LEF-1 mit den Ergebnissen dieser Dissertation als möglicher Regulator der Tumorprogression im Hodgkin-Lymphom charakterisiert werden.

\subsection{Ausblick}

In dieser Dissertation konnte das Verhalten von Hodgkin-Lymphom-Zellen im in ovo-CAMModell charakterisiert werden. Besonders hervorstehend waren dabei die histologischen Auffälligkeiten der entstandenen Tumoren: Das komplette Fehlen von Lymphgefäßen und die abnorme Struktur der Blutgefäße waren unerwartete und bisher nicht beschriebene Ergebnisse. Ein wichtiger Ansatz zur Vertiefung der hier erhobenen Daten sollten daher histologische Analysen von CAM-Tumoren in Abhängigkeit von der Zeit sein, um die zugrunde liegenden Vorgänge, die zur Anomalität der Gefäße geführt haben, genauer zu beschreiben. Dabei könnte sich am Vorgehen von Deryugina und Quigley (2008) orientiert werden, die solche histologischen Zeitreihen zur Untersuchung der Dissemination von Fibrosarkomzellen durchführten.

Um die mechanistischen Hintergründe dieses gravierenden Einflusses auf die Gefäßstruktur zu untersuchen, könnten - wie bereits beschrieben - mögliche verursachende Gene mittels RNA-Sequenzierung identifiziert und gezielt ausgeschaltet werden. In erneuten CAMVersuchen könnte dann der Einfluss dieser untersuchten Gene charakterisiert werden.

Ein weiterer Ansatzpunkt für weiterführende Versuche wäre die genauere Charakterisierung der Interaktion von LEF-1 und VEGF-A. Dabei ist insbesondere zu untersuchen, auf welche Weise LEF-1 die Sekretion von VEGF-A beeinflusst. Hierzu wären breiter angelegte ELISAMessungen durchzuführen, um die in dieser Dissertation beobachteten Schwankungen im VEGF-A-Gehalt der konditionierten Medien zu minimieren. 


\section{Zusammenfassung}

Das Hodgkin-Lymphom ist eines der häufigsten malignen Lymphome. Es kennzeichnet sich vor allem dadurch aus, dass nur ein sehr kleiner Teil des Tumors von malignen Zellen gebildet wird, während der Großteil aus einem reaktiven Infiltrat von Zellen des Immunsystems besteht. Aus diesem Grund ist die Interaktion der Tumorzellen mit den Zellen ihrer unmittelbaren Umgebung von außerordentlicher Bedeutung. Eine wichtige Rolle spielen dabei deregulierte intrazelluläre Signalwege. Der kanonische Wnt-Signalweg mit seinem Transkriptionsfaktor LEF-1 ist in vielen malignen Erkrankungen dereguliert, allerdings lagen bislang nur wenige Daten zur Relevanz im Hodgkin-Lymphom vor. Für einen stabilen LEF-1Knockdown wurden L-428-Zellen zweimal unabhängig voneinander lentiviral transduziert. Neben LEF-1-defizienten Zellen wurden die jeweiligen Kontrollen in vitro und im in ovo-CAMModell untersucht. Weiterhin wurde untersucht, inwieweit HL-Zellen mit Endothelzellen interagieren und ob diese Interaktion LEF-1-abhängig ist.

Es konnte beobachtet werden, dass HL-Zellen im CAM-Xenograft-Modell stark eingeblutete Tumoren bilden. Histologische Untersuchungen zeigten, dass die Blutgefäße innerhalb dieser Tumoren sind bizarr und unregelmäßig konfiguriert sind und große Einblutungen im Umfeld dieser Gefäße vorliegen. Weiterhin konnte ein vollständiges Fehlen von Lymphgefäßen in den Tumoren beobachtet werden.

Der LEF-1-Knockdown führte im in ovo-CAM-Modell einer der beiden Transduktionen zur Bildung signifikant kleinerer Tumoren. Dabei hatte LEF-1 keinen Einfluss auf die Größe und Intensität der Einblutungen. Mittels Migrationsanalysen von HUVEC-Zellen konnte demonstriert werden, dass konditionierte Medien von HL-Zellen in der Lage sind, Endothelzellen zur Migration zu stimulieren, was eine wichtige Voraussetzung zur Angiogenese darstellt. Diese Fähigkeit zur Stimulation der Migration von Endothelzellen ist in L-428-Zellen LEF-1-abhängig. Dieser Effekt könnte teilweise über eine Beeinflussung der Sekretion von VEGF-A durch LEF-1 vermittelt sein, in dieser Hinsicht ist aber auf Basis der hier erhobenen Daten keine sichere Aussage möglich.

Diese Ergebnisse beschreiben zum ersten Mal den Einfluss des Transkriptionsfaktors LEF-1 im Hodgkin-Lymphom und charakterisieren ihn als einen potentiellen Tumorprogressionsfaktor. LEF-1 scheint einen Einfluss auf das Tumorwachstum zu haben und kann zur Fähigkeit von HL-Zellen, Angiogenese zu stimulieren, beitragen. LEF-1 könnte daher langfristig einen Kandidaten für eine zielgerichtete Therapie im Hodgkin-Lymphom darstellen. 


\section{Literaturverzeichnis}

Aberle H, Bauer A, Stappert J, Kispert A, Kemler R (1997): $\beta$-catenin is a target for the ubiquitinproteasome pathway. EMBO J 16, 3797-3804

Adams RH, Alitalo K (2007): Molecular regulation of angiogenesis and lymphangiogenesis. Nat Rev Mol Cell Biol $\underline{8}$, 464-478

Aldinucci D, Gloghini A, Pinto A, Filippi R De, Carbone A (2010): The classical Hodgkin's lymphoma microenvironment and its role in promoting tumour growth and immune escape. J Pathol 221 , 248-263

Ansell SM (2014): CME Information: Hodgkin lymphoma : 2014 Update. Am J Hematol 89, 771-779

Arce L, Yokoyama NN, Waterman ML (2006): Diversity of LEF/TCF action in development and disease. Oncogene 25, 7492-7504

Archbold HC, Yang YX, Chen L, Cadigan KM (2012): How do they do Wnt they do?: regulation of transcription by the Wnt/ $\beta$-catenin pathway. Acta Physiol 204, 74-109

Baek ST, Kerjan G, Bielas SL, Lee JE, Fenstermaker AG, Novarino G, Gleeson JG (2014): Off-target effect of doublecortin family shRNA on neuronal migration associated with endogenous MicroRNA dysregulation. Neuron $\underline{82}, 1255-1262$

Bargou RC, Leng C, Krappmann D, Emmerich F, Mapara MY, Bommert K, Royer HD, Scheidereit C, Dörken B (1996): High-level nuclear NF-kappa B and Oct-2 is a common feature of cultured

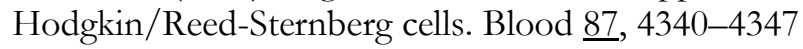

Basso K, Dalla-Favera R (2015): Germinal centres and B cell lymphomagenesis. Nat Rev Immunol $\underline{15}$, 172-184

Behrens J, von Kries JP, Kühl M, Bruhn L, Wedlich D, Grosschedl R, Birchmeier W (1996): Functional interaction of $\beta$-catenin with the transcription factor LEF-1. Nature $\underline{382}$, 638-642

Bhanot P, Brink M, Harryman Samos C, Hsieh J-C, Wang Y, Macke JP, Andrew D, Nathans J, Nusse R (1996): A new member of the frizzled family from Drosophila functions as a Wingless receptor. Nature $\underline{382}, 225-230$

Bienz M, Clevers H (2000): Linking Colorectal Cancer to Wnt Signaling Review. Cell 103, 311-320

Bilic J, Huang Y-L, Davidson G, Zimmermann T, Cruciat C-M, Bienz M, Niehrs C (2007): Wnt induces LRP6 signalosomes and promotes dishevelled-dependent LRP6 phosphorylation. Science 316, 1619-22

De Bock K, Cauwenberghs S, Carmeliet P (2011): Vessel abnormalization: another hallmark of cancer? Molecular mechanisms and therapeutic implications. Curr Opin Genet Dev 21, 73-79

Bradford MM (1976): A rapid and sensitive method for the quantitation of microgram quantities of protein utilizing the principle of protein-dye binding. Anal Biochem $\underline{72}, 248-254$

Carbone PP, Kaplan HS, Musshoff K, Smithers DW, Tubiana M (1971): Report of the Committee on Hodgkin's Disease Staging Classification. Cancer Res $\underline{31}$, 1860-1861

Cardesa-Salzmann TM, Colomo L, Gutierrez G, Chan WC, Weisenburger D, Climent F, GonzálezBarca E, Mercadal S, Arenillas L, Serrano S, et al. (2011): High microvessel density determines a poor outcome in patients with diffuse large B-cell lymphoma treated with rituximab plus chemotherapy. Haematologica 96, 996-1001

Carmeliet P, Jain RK (2011): Molecular mechanisms and clinical applications of angiogenesis. Nature $\underline{473}, 298-307$ 
Celegato M, Borghese C, Casagrande N, Mongiat M, Kahle XU, Paulitti A, Spina M, Colombatti A, Aldinucci D (2015): Preclinical activity of the repurposed drug auranofin in classical Hodgkin lymphoma. Blood 126, 1394-1397

Chappell JC, Wiley DM, Bautch VL (2011): Regulation of blood vessel sprouting. Semin Cell Dev Biol $\underline{22}, 1005-1011$

Claesson-Welsh L, Welsh M (2013): VEGFA and tumour angiogenesis. J Intern Med 273, 114-127

Clevers H (2006): Wnt/beta-catenin signaling in development and disease. Cell 127, 469-80

Derksen PWB, Tjin E, Meijer HP, Klok MD, MacGillavry HD, van Oers MHJ, Lokhorst HM, Bloem AC, Clevers H, Nusse R, et al. (2004): Illegitimate WNT signaling promotes proliferation of multiple myeloma cells. Proc Natl Acad Sci U S A 101, 6122-6127

Deryugina EI, Quigley JP (2008): Chick embryo chorioallantoic membrane model systems to study and visualize human tumor cell metastasis. Histochem Cell Biol 130, 1119-1130

Diefenbach C, Steidl C (2013): New strategies in Hodgkin lymphoma: better risk profiling and novel treatments. Clin Cancer Res 19, 2797-2803

Doussis-Anagnostopoulou I a, Talks KL, Turley H, Debnam P, Tan DC, Mariatos G, Gorgoulis V, Kittas C, Gatter KC (2002): Vascular endothelial growth factor (VEGF) is expressed by neoplastic Hodgkin-Reed-Sternberg cells in Hodgkin's disease. J Pathol 197, 677-683

Dudley AC (2012): Tumor endothelial cells. Cold Spring Harb Perspect Med 2, a006536

Eberle FC, Mani H, Jaffe ES (2009): Histopathology of Hodgkin's lymphoma. Cancer J 15, 129-137

Ebos JML, Lee CR, Cruz-Munoz W, Bjarnason GA, Christensen JG, Kerbel RS (2009): Accelerated Metastasis after Short-Term Treatment with a Potent Inhibitor of Tumor Angiogenesis. Cancer Cell 15, 232-239

Eilken HM, Adams RH (2010): Dynamics of endothelial cell behavior in sprouting angiogenesis. Curr Opin Cell Biol 22, 617-625

Ekström EJ, Bergenfelz C, von Bülow V, Serifler F, Carlemalm E, Jönsson G, Andersson T, Leandersson K (2014): WNT5A induces release of exosomes containing pro-angiogenic and immunosuppressive factors from malignant melanoma cells. Mol Cancer $\underline{13}, 88-102$

Engert A, Diehl V, Franklin J, Lohri A, Dorken B, Ludwig W-D, Koch P, Hanel M, Pfreundschuh M, Wilhelm M, et al. (2009): Escalated-Dose BEACOPP in the Treatment of Patients With Advanced-Stage Hodgkin's Lymphoma: 10 Years of Follow-Up of the GHSG HD9 Study. J Clin Oncol 27, 4548-4554

Estrada-Bernal A, Mendoza-Milla C, Ventura-Gallegos JL, López-Bojórquez LN, Miranda-Peralta E, Arechavaleta-Velasco F, Vadillo-Ortega F, Sánchez-Sánchez L, Zentella-Dehesa A (2003): NFkappaB dependent activation of human endothelial cells treated with soluble products derived from human lymphomas. Cancer Lett 191, 239-248

Falk MH, Tesch H, Stein H, Diehl V, Jones DB, Fonatsch C, Bornkamm GW (1987): Phenotype versus immunoglobulin and T-cell receptor genotype of Hodgkin-derived cell lines: Activation of immature lymphoid cells in Hodgkin's disease. Int J Cancer 40, 262-269

Ferrara N, Henzel WJ (1989): Pituitary follicular cells secrete a novel heparin-binding growth factor specific for vascular endothelial cells. Biochem Biophys Res Commun 161, 851-858

Ferrara N, Davis-Smyth T (1997): The Biology of Vascular Endothelial Growth Factor. Endocr Rev $\underline{18}, 4-25$

Ferrara N, Gerber H-P, LeCouter J (2003): The biology of VEGF and its receptors. Nat Med $\underline{9}, 669$ 676

Folkman J (1971): Tumor angiogenesis: therapeutic implications. N Engl J Med 285, 1182-1186 
Gelebart P, Anand M, Armanious H, Peters AC, Bard JD, Amin HM, Lai R, Dien Bard J, Amin HM, Lai R (2008): Constitutive activation of the Wnt canonical pathway in mantle cell lymphoma. Blood 112, 5171-5179

van Genderen C, Okamura RM, Farinas I, Quo R-G, Parslow TG, Bruhn L, Grosschedl R (1994): Development of several organs that require inductive epithelial-mesenchymal interactions is impaired in LEF-1 deficient mice. Genes Dev $\underline{8}, 2691-2703$

Girard J-P, Moussion C, Förster R (2012): HEVs, lymphatics and homeostatic immune cell trafficking in lymph nodes. Nat Rev Immunol $\underline{12}, 762-773$

Glaser SL, Lin RJ, Stewart SL, Ambinder RF, Jarrett RF, Brousset P, Pallesen G, Gulley ML, Khan G, O’Grady J, et al. (1997): Epstein-Barr Virus-Associated Hodgkin's Disease : Epidemiologic Characteristics in International Data. Int J Cancer $\underline{70}$, 375-382

Groden J, Thliveris A, Samowitz W, Carlson M, Gelbert L, Albertsen H, Joslyn G, Stevens J, Spirio L, Robertson M, et al. (1991): Identification and Characterization of the Familial Adenomatous Polyposis Coli Gene. Cell $\underline{66}$, 589-600

Grufferman S, Cole P, Smith PG, Lukes RJ (1977): Hodgkin's disease in siblings. N Engl J Med 296, $248-250$

Guermazi A, Brice P, de Kerviler E E, Fermé C, Hennequin C, Meignin V, Frija J (2001): Extranodal Hodgkin disease: spectrum of disease. Radiographics 21, 161-179

Gutierrez A, Tschumper RC, Wu X, Shanafelt TD, Eckel-Passow J, Huddleston PM, Slager SL, Kay NE, Jelinek DF (2010): LEF-1 is a prosurvival factor in chronic lymphocytic leukemia and is expressed in the preleukemic state of monoclonal B-cell lymphocytosis. Blood 116, 2975-2983

Hamel KM, Liarski VM, Clark MR (2012): Germinal Center B-cells. Autoimmunity 4ㄷ, 333-347

Hanahan D, Weinberg RA (2000): The Hallmarks of Cancer. Cell 100, 57-70

Hanahan D, Weinberg RA (2011): Hallmarks of cancer: the next generation. Cell 144, 646-674

Herold G: Innere Medizin. Gerd Herold (Verlag), Köln 2014

Hodgkin T (1832): On some morbid appearances of the absorbent glands and spleen. Med Chir Trans 17, 68-114

Irvin M, Zijlstra A, Wikswo J, Pozzi A (2014): Techniques and assays for the study of angiogenesis. Exp Biol Med 239, 1476-1488

Jinek M, Chylinski K, Fonfara I, Hauer M, Doudna JA, Charpentier E (2012): A programmable dualRNA-guided DNA endonuclease in adaptive bacterial immunity. Science $\underline{337}, 816-821$

Kanzler H, Küppers R, Hansmann M-L, Rajewsky K (1996): Hodgkin and Reed-Sternberg Cells in Hodgkin's Disease Represent the Outgrowth of a Dominant Tumor Clone Derived from (Crippled) Germinal Center B Cells. J Exp Med 184, 1495-1505

Kieran MW, Kalluri R, Cho Y (2012): The VEGF Pathway in Cancer and Disease: Responses, Resistance, and the Path Forward. Cold Spring Harb Perspect Med 2, 1-17

Kinzler KW, Vogelstein B (1996): Lessons from Hereditary Colorectal Cancer. Cell 87, 159-170

Klaus A, Birchmeier W (2008): Wnt signalling and its impact on development and cancer. Nat Rev Cancer $\underline{8}, 387-398$

Klingenberg M, Becker J, Eberth S, Kube D, Wilting J (2014): The chick chorioallantoic membrane as an in vivo xenograft model for Burkitt lymphoma. BMC Cancer 14, 339-350

Korinek V, Barker N, Morin PJ, van Wichen D, de Weger R, Kinzler KW, Vogelstein B, Clevers H (1997): Constitutive transcriptional activation by a beta-catenin-Tcf complex in APC-/- colon carcinoma. Science $\underline{275}, 1784-1787$ 
Korkolopoulou P, Thymara I, Kavantzas N, Vassilakopoulos TP, Angelopoulou MK, Kokoris SI, Dimitriadou EM, Siakantaris MP, Anargyrou K, Panayiotidis P, et al. (2005): Angiogenesis in Hodgkin's lymphoma: A morphometric approach in 286 patients with prognostic implications. Leukemia 19 , 894-900

Kube D, Holtick U, Vockerodt M, Ahmadi T, Haier B, Behrmann I, Heinrich PC (2001): STAT3 is constitutively activated in Hodgkin cell lines. Blood $\underline{98}$, 762-770

Kühnl A, Gökbuget N, Kaiser M, Schlee C, Stroux A, Burmeister T, Mochmann LH, Hoelzer D, Hofmann W-K, Thiel E, Baldus CD (2011): Overexpression of LEF1 predicts unfavorable outcome in adult patients with B-precursor acute lymphoblastic leukemia. Blood $\underline{118}$, 6362-6367

Küppers R (2009): The biology of Hodgkin's lymphoma. Nat Rev Cancer 무, 15-27

Küppers R, Rajewsky K, Zhaot M, Simonst G, Laumann R, Fischer R, Hansmann M (1994): Hodgkin disease: Hodgkin and Reed-Sternberg cells picked from histological sections show clonal immunoglobulin gene rearrangements and appear to be derived from $\mathrm{B}$ cells at various stages of development. Proc Natl Acad Sci U S A 91, 10962-10966

Küppers R, Engert A, Hansmann M (2012): Hodgkin lymphoma. J Clin Invest 122, 3439-3447

Labidi SI, Ménétrier-Caux C, Chabaud S, Chassagne C, Sebban C, Gargi T, Biron P, Blay J-Y, Ghesquières H (2010): Serum cytokines in follicular lymphoma. Correlation of TGF- $\beta$ and

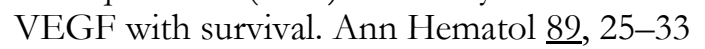

Laemmli UK (1970): Cleavage of structural proteins during the assembly of the head of bacteriophage T4. Nature 227, 680-685

LeMieux MH, Solanki A a, Mahmood U, Chmura SJ, Koshy M (2015): Risk of second malignancies in patients with early-stage classical Hodgkin's lymphoma treated in a modern era. Cancer Med $\underline{4}$, $513-518$

Lin SY, Xia W, Wang JC, Kwong KY, Spohn B, Wen Y, Pestell RG, Hung MC (2000): Beta-catenin, a novel prognostic marker for breast cancer: its roles in cyclin D1 expression and cancer progression. Proc Natl Acad Sci U S A 97, 4262-4266

Linke F: WNT signalling affects cell migration, invasion and the lymphoma-endothelial interplay in Hodgkin Lymphoma. Dissertation Göttingen 2016

Liu Y, Sattarzadeh A, Diepstra A, Visser L, van den Berg A (2014): The microenvironment in classical Hodgkin lymphoma: an actively shaped and essential tumor component. Semin Cancer Biol $\underline{24}$, $15-22$

Lu D, Zhao Y, Tawatao R, Cottam HB, Sen M, Leoni LM, Kipps TJ, Corr M, Carson D a (2004): Activation of the Wnt signaling pathway in chronic lymphocytic leukemia. Proc Natl Acad Sci U S A $101,3118-3123$

Marinaccio C, Nico B, Maiorano E, Specchia G, Ribatti D (2014): Insights in Hodgkin Lymphoma angiogenesis. Leuk Res $\underline{38}, 857-861$

Matsumoto K, Ema M (2014): Roles of VEGF-A signalling in development, regeneration, and tumours. J Biochem 156, 1-10

Menter T, Dirnhofer S, Tzankov A (2015): LEF1: a highly specific marker for the diagnosis of chronic lymphocytic B cell leukaemia/small lymphocytic B cell lymphoma. J Clin Pathol $\underline{68}$, 473-478

Montanari F, Diefenbach C (2014): Relapsed Hodgkin lymphoma: management strategies. Curr Hematol Malig Rep 2, 284-293

Mullighan CG, Goorha S, Radtke I, Miller CB, Coustan-Smith E, Dalton JD, Girtman K, Mathew S, Ma J, Pounds SB, et al. (2007): Genome-wide analysis of genetic alterations in acute lymphoblastic leukaemia. Nature $\underline{446}, 758-764$

Munemitsu S, Albert I, Souza B, Rubinfeld B, Polakis P (1995): Regulation of intracellular $\beta$-catenin levels by the adenomatous polyposis coli (APC) tumor-suppressor protein. Proc Natl Acad Sci U S A $\underline{92}, 3046-3050$ 
Nusse R, Brown A, Papkoff J, Scambler P, Shackleford G, McMahon A, Moon R, Varmus H (1991): A new nomenclature for int-1 and related genes: the Wnt gene family. Cell 64, 231

Passalidou E, Stewart M, Trivella M, Steers G, Pillai G, Dogan A, Leigh I, Hatton C, Harris A, Gatter $\mathrm{K}$, Pezzella F (2003): Vascular patterns in reactive lymphoid tissue and in non-Hodgkin's lymphoma. Br J Cancer $\underline{88}, 553-559$

Polakis P (2007): The many ways of Wnt in cancer. Curr Opin Genet Dev 17, 45-51

Polakis P (2012): Wnt signaling in cancer. Cold Spring Harb Perspect Biol 4, a008052

Potente M, Gerhardt H, Carmeliet P (2011): Basic and therapeutic aspects of angiogenesis. Cell 146, 873-887

Reya T, Riordan MO, Okamura R, Devaney E, Willert K, Nusse R, Grosschedl R (2000): Wht Signaling Regulates B Lymphocyte Proliferation through a LEF-1 Dependent Mechanism. Immunity $\underline{13}, 15-24$

Ribatti D (2014): The chick embryo chorioallantoic membrane as a model for tumor biology. Exp Cell Res $\underline{328}, 314-324$

Ribatti D, Vacca A, Nico B, Fanelli M, Roncali L, Dammacco F (1996): Angiogenesis spectrum in the stroma of B-cell non-Hodgkin's lymphomas. An immunohistochemical and ultrastructural study. Eur J Haematol $\underline{56}, 45-53$

Ribatti D, Nico B, Ranieri G, Specchia G, Vacca A (2013): The Role of Angiogenesis in Human NonHodgkin Lymphomas. Neoplasia $\underline{15}, 231-238$

Roorda BD, ter Elst A, Scherpen FJ, Meeuwsen-de Boer TG, Kamps W, de Bont ES (2010): VEGF-A promotes lymphoma tumour growth by activation of STAT proteins and inhibition of $\mathrm{p} 27 \mathrm{KIP} 1$ via paracrine mechanisms. Eur J Cancer 46, 974-982

Sánchez-Rivera FJ, Jacks T (2015): Applications of the CRISPR-Cas9 system in cancer biology. Nat Rev Cancer 15, 387-395

Schaadt M, Fonatsch C, Kirchner H, Diehl V (1979): Establishment of a malignant, epstein-barr-virus (EBV)-negative cell-line from the pleura effusion of a patient with Hodgkin's disease. Blut $\underline{38}$, 185-190

Scheeren FA, Diehl SA, Smit LA, Beaumont T, Naspetti M, Bende RJ, Blom B, Karube K, Ohshima K, Noesel CJM Van, Spits H (2008): IL-21 is expressed in Hodgkin lymphoma and activates STAT5 : evidence that activated STAT5 is required for Hodgkin lymphomagenesis. Blood 111 , 4706-4716

Schmitz N, Pfistner B, Sextro M, Sieber M, Carella AM, Haenel M, Boissevain F, Zschaber R, Müller P, Kirchner H, et al. (2002): Aggressive conventional chemotherapy compared with high-dose chemotherapy with autologous haemopoietic stem-cell transplantation for relapsed chemosensitive Hodgkin 's disease : a randomised trial. Lancet $\underline{359}$, 2065-2071

Schwering I, Bräuninger A, Klein U, Jungnickel B, Tinguely M, Diehl V, Hansmann M-L, Dalla-Favera R, Rajewsky K, Küppers R (2003): Loss of the B-lineage - specific gene expression program in Hodgkin and Reed-Sternberg cells of Hodgkin lymphoma. Blood 101, 1505-1512

Shitashige M, Hirohashi S, Yamada T (2008): Wnt signaling inside the nucleus. Cancer Sci 모, 631-637

Shweiki D, Itin A, Soffer D, Keshet E (1992): Vascular endothelial growth factor induced by hypoxia may mediate hypoxia-initiated angiogenesis. Nature $\underline{359}$, 843-845

Song HW, Bettegowda A, Oliver D, Yan W, Phan MH, De Rooij DG, Corbett MA, Wilkinson MF (2015): shRNA off-target effects in vivo: Impaired endogenous siRNA expression and spermatogenic defects. PLoS One $\underline{10}, 1-23$

Steidl C, Lee T, Shah SP, Farinha P, Han G, Nayar T, Delaney A, Jones SJ, Iqbal J, Weisenburger DD, et al. (2010): Tumor-associated macrophages and survival in classic Hodgkin's lymphoma. N Engl J Med $\underline{362}, 875-85$ 
Steidl C, Connors JM, Gascoyne RD (2011): Molecular pathogenesis of Hodgkin's lymphoma: increasing evidence of the importance of the microenvironment. J Clin Oncol 29, 1812-26

Swerdlow SH, Campo E, Harris NL, Jaffe ES, Pileri SA, Stein H, Thiele J, Vardiman J: WHO Classification of Tumours of Haematopoietic and Lymphoid Tissues. 4. Auflage; World Health Organization, Genf 2008

Thomas RK, Re D, Zander T, Wolf J, Diehl V (2002): Epidemiology and etiology of Hodgkin's lymphoma. Ann Oncol 13, 147-152

Thomas RK, Re D, Wolf J, Diehl V (2004): Part I : Hodgkin's lymphoma — molecular biology of Hodgkin and Reed-Sternberg cells. Lancet Oncol $\underline{5}, 11-18$

Travis A, Amsterdam A, Belanger C, Grosschedl R (1991): LEF-1, a gene encoding a lymphoidspecific with protein, an HMG domain, regulates T-cell receptor enhancer function. Genes Dev $\underline{5}, 880-894$

Ueberdiek S: Einfluss von LEF1 auf das Tumorwachstum im Burkitt-Lymphom-Xenograft-Modell. Med. Diss. Göttingen 2016

Veeman MT, Axelrod JD, Moon RT (2003): A Second Canon: Functions and Mechanisms of $\beta$ Catenin-Independent Wnt Signaling. Dev Cell $\underline{5}, 367-377$

Venkataraman G, Mirza MK, Eichenauer D a, Diehl V (2014): Current status of prognostication in classical Hodgkin lymphoma. Br J Haematol 165, 287-299

Vinuesa CG, Linterman MA, Goodnow CC, Randall KL (2010): T cells and follicular dendritic cells in germinal center B-cell formation and selection. Immunol Rev 237, 72-89

Walther N, Ulrich A, Vockerodt M, von Bonin F, Klapper W, Meyer K, Eberth S, Pukrop T, Spang R, Trümper L, Kube D (2013): Aberrant lymphocyte enhancer-binding factor 1 expression is characteristic for sporadic Burkitt's lymphoma. Am J Pathol 182, 1092-1098

Wang W-J, Yao Y, Jiang L-L, Hu T-H, Ma J-Q, Liao Z-J, Yao J-T, Li D-F, Wang S-H, Nan K-J (2013): Knockdown of lymphoid enhancer factor 1 inhibits colon cancer progression in vitro and in vivo. PLoS One $\underline{8}$, e76596

Waterman ML, Jones KA (1990): Purification of TCF-1 alpha, a T-cell-specific transcription factor that activates the $\mathrm{T}$-cell receptor $\mathrm{C}$ alpha gene enhancer in a context-dependent manner. New Biol 2 , 621-636

Welti J, Loges S, Dimmeler S, Carmeliet P (2013): Recent molecular discoveries in angiogenesis and antiangiogenic therapies in cancer. J Clin Invest $\underline{123}, 3190-3200$

Wilming P: Untersuchungen zur Angiogenese des Burkitt-Lymphoms unter besonderer Berücksichtigung des Lymphocyte Enhancer-binding Factor-1. Med. Diss. Göttingen 2017

Yang J, Li W, He X, Zhang G, Yue L, Chai Y (2015): VEGF Overexpression Is a Valuable Prognostic Factor for Non-Hodgkin's Lymphoma Evidence from a Systemic Meta-Analysis. Dis Markers $\underline{2015}, 1-9$

Younes A, Bartlett NL, Leonard JP, Kennedy DA, Lynch CM, Sievers EL, Forero-Torres A (2010): Brentuximab Vedotin (SGN-35) for Relapsed CD30-Positive Lymphomas. N Engl J Med $\underline{363}$, 1812-1821

\section{Internetquellen}

Jeremy Abramson, MD; Massachusetts General Hospital: Avastin (Bevacizumab) Plus Adriamycin, Bleomycin, Vinblastine and Dacarbazine (ABVD) for Advanced Stage Hodgkin Lymphoma. URL: https://clinicaltrials.gov/ct2/show/study/NCT00722865

letzter Zugriff am 4. Dezember 2017 


\section{Danksagung}

An erster Stelle möchte ich meinem Doktorvater Prof. Dr. Dieter Kube für die Überlassung dieses interessanten Themas und für die häufigen und immer hilfreichen Gespräche danken. Nicht viele Doktoranden haben einen so gut erreichbaren Doktorvater, der einem bei allen Belangen gerne hilft, danke dafür!

Darüber hinaus danke ich Prof. Dr. Lorenz Trümper für die Möglichkeit, in seiner Abteilung für Hämatologie und Medizinische Onkologie zu promovieren.

Frederike von Bonin danke ich für die häufige technische Unterstützung, für die Einarbeitung in verschiedenste Versuche und für ihre ständige Ansprechbarkeit und Hilfsbereitschaft.

Ein großes Dankeschön geht auch an Prof. Dr. Jörg Wilting für die Möglichkeit, in seiner Arbeitsgruppe für Zellbiologie Versuche absolvieren zu dürfen und für die Hilfe bei der Aufarbeitung und der Interpretation der histologischen Daten. Ebenso danke ich seinen Mitarbeitern Christina Zelent, Sonja Schwoch und insbesondere Berti Manshausen, die mich im Institut für Anatomie und Zellbiologie immer unterstützt haben und die die vielen Stunden dort immer gut gelaunt begleitet haben.

Bei Maren Feist, Isabell Rausch und Annekatrin Arlt bedanke ich mich für die vielen Tipps im Labor und Büro und für die tolle Arbeitsatmosphäre.

Ein besonderer Dank gilt Sebastian Zaunig, der mich zu Beginn meiner Doktorarbeit mit viel Geduld eingearbeitet hat und auch danach ein toller Laborbegleiter war! Ebenso möchte ich mich bei meiner guten Freundin Judith Kemper bedanken, die kurz nach mir in die Arbeitsgruppe kam und mit der es immer eine Freude war zusammenzuarbeiten!

Überdies bin ich Herrn Dr. Herbert Weich vom Helmholtz-Institut in Braunschweig für die Durchführung des VEGF-A-ELISA äußerst dankbar. Ohne ihn würde ein wichtiger Baustein dieser Arbeit fehlen.

$\mathrm{Zu}$ guter Letzt möchte ich meiner Betreuerin und guten Freundin Franziska Linke danken, ohne die diese Arbeit definitiv nicht zu Stande gekommen wäre. Tausend Dank für aufbauende Worte, wenn mal wieder ein Versuch nicht geklappt hat, für Unterstützung und Motivation, für eine tolle Zeit auf dem Kongress in Basel und für die Korrekturen am Manuskript. 